UNIVERSIDADE DE SÃO PAULO

ESCOLA DE ENFERMAGEM

JULIANE CRISTINA BURGATTI

REVISÃO SISTEMÁTICA SOBRE O USO DE AVENTAIS CIRÚRGICOS, CONFORME O MATERIAL DE CONFECÇÃO, NO CONTROLE DA CONTAMINAÇÃO/INFECÇÃO DO SÍTIO CIRÚRGICO. 
JULIANE CRISTINA BURGATTI

\section{REVISÃO SISTEMÁTICA SOBRE O USO DE AVENTAIS CIRÚRGICOS, CONFORME O MATERIAL DE CONFECÇÃO NO CONTROLE DA CONTAMINAÇÃO/INFECÇÃO DO SÍTIO CIRÚRGICO.}

Dissertação apresentada à Escola de Enfermagem da Universidade de São Paulo para obtenção do título de mestre em Enfermagem. Área de Concentração: Saúde do Adulto.

Orientadora:

Prof. ${ }^{\text {a }}$ Dr. ${ }^{\text {a }}$ Rúbia A. Lacerda

SÃO PAULO 


\section{Catalogação na Publicação (CIP) Biblioteca "Wanda de Aguiar Horta" Escola de Enfermagem da Universidade de São Paulo}

Burgatti, Juliane Cristina.

Revisão sistemática sobre o uso de aventais cirúrgicos, conforme o material de confecção, no controle da contaminação/infecção do sítio cirúrgico. / Juliane Cristina Burgatti. - São Paulo, 2007.

$150 \mathrm{p}$.

Dissertação (Mestrado) - Escola de Enfermagem da Universidade de São Paulo.

Orientadora: Prof ${ }^{\mathrm{a}} \mathrm{Dr}^{\mathrm{a}}$ Rúbia Aparecida Lacerda

1. Ferida cirúrgica (contaminação) 2. Infecções bacterianas. 3 . Infecção hospitalar (controle). I. Título. 


\section{DEDICATÓRIA}

Para minha querida mãe e irmão,

Porfazer parte de minha vida, todo o meu amor.

Para meu querido esposo,

Pela compreensão nos momentos de ausência, todo o meu amor. 


\section{AGRADECIMENTOS}

À Prof. ${ }^{a}$ Rúbia Aparecida Lacerda,

Por sua competência e dedicação.

À Profa Kazuko,

Pelo apoio e colaboração.

À Maria Eugênia, Wanise e toda equipe de trabalho do HSPM, Pelo incentivo.

Aos familiares, amigas (os) e colegas,

Por torcerem por mim. 


\section{RESUMO}

BURGATTI, J.C. Revisão sistemática sobre o uso de aventais cirúrgicos, conforme o material de confecção, no controle da contaminação/infecção do sítio cirúrgico. 2007, 150p. Dissertação (Mestrado) - Escola de Enfermagem da Universidade de São Paulo, São Paulo, 2007.

O avental cirúrgico, um dos principais componentes de barreira antimicrobiana, é confeccionado com materiais de tecido e não-tecido. A Sociedade Norte-Americana de Enfermeiros do Centro Cirúrgico - AORN e a Norma Européia - EN 13795-3 recomendam que os aventais cirúrgicos devam prover uma barreira apropriada contra microrganismos, sangue e outros fluidos corpóreos (seco ou molhado). Tais recomendações, no entanto, não definem o que consideram como "barreira apropriada". O que ainda não foi comprovado, porém, é se o uso de materiais de nãotecido realmente interfere, isoladamente, tanto na contaminação da ferida operatória, quanto na ocorrência de ISC. O presente estudo teve como objetivo verificar se há evidências científicas, pela revisão sistemática de literatura, que fundamentem a prática do uso de aventais em cirurgias, conforme seu material de confecção. Foram considerados para a revisão sistemática apenas estudos básicos de intervenção, que investigaram a contaminação e ou a infecção do sítio cirúrgico com uso de aventais cirúrgicos reutilizáveis e ou de uso-único, utilizando como população pessoas submetidas a cirurgias, em situações reais ou simuladas, em qualquer período, sem limitação de idioma. Para localizar os estudos, utilizou-se a estratégia: P (pacientes) $=$ pacientes cirúrgicos - surgical patients, $\mathrm{I}$ (intervenção) $=$ roupa hospitalar ou roupa de proteção - clothing / protective clothing, C (comparação) $=$ uso-único ou reutilizável - single-use or reusable, $\mathrm{O}$ (desfecho) = contaminação ou infecção da ferida operatória - surgical wound infection/contamination. A busca dos estudos orientou-se pelas bases de dados eletrônicas: LILACS, CINAHL, EMBASE, COCHRANE, PubMed/MEDLINE, pesquisa manual na revista da Sociedade Brasileira de Enfermeiros de Centro Cirúrgico (SOBECC) e referências dos estudos incluídos. Os dados analisados foram apresentados em três fases: Fase 1: Caracterização do processo de seleção dos estudos; Fase 2: Caracterização dos estudos incluídos; Fase 3: Avaliação da evidência dos estudos incluídos, a partir de duas escalas de qualidade, sendo uma delas a de Jadad e outra a de Controle de Infecção Cirúrgica (EQCIC), adaptada de Nobre e Bernardo. A amostra desta revisão sistemática constituiu-se de 12 estudos, sendo que apenas um deles investigou o avental isoladamente. Os demais investigaram principalmente os campos cirúrgicos juntamente com os aventais. Constata-se, com isso, dificuldade de isolar o objeto de intervenção de outros inúmeros fatores que podem interferir nos desfechos, em estudos desta natureza. Dois estudos (E1, E2) obtiveram forte evidência de recomendação, concluindo pela não diferença de contaminação e infecção do sítio cirúrgico entre aventais e campos de tecido e não-tecido. Devido à ausência de estudos semelhantes não houve a possibilidade de realizar a metanálise. A 
verificação isolada de aventais cirúrgicos depende de mais pesquisas bem controladas e delineadas. A contribuição desta investigação para a implementação de prática baseada em evidências mostrou-se relevante não somente para responder especificamente à questão da pesquisa, mas também para identificar qualidade, lacunas, falhas e recomendar aspectos a serem considerados nas próximas pesquisas desta natureza.

Palavras-chave: 1. Aventais cirúrgicos, 2. Infecção do sítio cirúrgico, 3. Infecção de ferida operatória, 4. Contaminação da ferida operatória 


\begin{abstract}
BURGATTI, J.C. Systematic revision about the use of surgical gowns, according to the confection material, in the control contamination / surgical site infection. 2007, 150p. Dissertation. Nursing School of the University of São Paulo, São Paulo, 2007.
\end{abstract}

The surgical gown, one of the main components of the antimicrobial barrier, is confectioned with woven and non-woven materials. The American Operating Room Nursing - AORN and The European Norm - EN 13795-3 recommend that the surgical gowns should provide an appropriate barrier against microorganisms, blood and other organic fluids (dry or wet). These recommendations, however, do not define, yet, what to consider an "appropriate barrier".. What has not been proved yet is if the use of non-woven materials influence, in an isolated way, both the contamination of an operation wound, and the occurrence of ISC. It was the objective of this present study to investigate if there is scientific evidence, by means of systematic revision, that founded the practice of use of gowns in surgery, according to its material of confections. Only basic studies of intervention that investigated the contamination and or surgical site infection with the use of surgical gowns reusable or single-use were considered in the systematic revision, which used as population people who underwent surgery, in real or simulated situations, in any period, without idiom limitation. To locate the studies, we used the PICO strategy: P (patients): surgical patients, I (intervention) $=$ clothing/protective clothing, $\mathrm{C}$ (comparison) $=$ single-use or reusable, $\mathrm{O}$ (outcome) = contamination or surgical wound infection. The search of studies was guided by the following electronic data bases: LILACS, PubMed/MEDLINE, EMBASE, COCHRANE, CINAHL, manual research in the magazine of Brazilian Society Operating Room Nursing (SOBECC) and references of included studies. The data analyses were shown in three phases: Phase 1: characterization of process of select studies; Phase 2: characterization of included studies; Phase 3: evaluation of the evidence found in the included studies, using two quality scales, being one this The Jadad and other Surgical Infection Control (EQCIC), adapted from Nobre and Bernardo. The sample of this systematic revision comprises 12 studies, being only one of them analyzed only gowns. The remainder investigated mainly the surgical fields together with the gowns. We can see thereby the difficulty in isolating the object of intervention from other countless factors that can influence outcomes, in studies of this nature. Two studies (E1, E2) found strong evidence of recommendation, concluding that there is no difference in terms of contamination and surgical wound infection between woven and non-woven gowns and drapes. Due to the absence of similar studies it is not possible to do some metanalysis. The isolated verification of surgical gowns needs more well controlled and delineated research. The contribution of this investigation to the implementation of practices based on evidences in showed relevant not only to answer specifically 
the question of research, but also to identify quality, gaps and flaws and recommend aspects to be considered in future research of this nature.

Key-words: 1. Surgical gowns, 2. Surgical Wound Infection, 3. Surgical Site Infection, 4. Surgical wound contamination 


\section{LISTA DE QUADROS}

Quadro 1 - Modelo preditivo de ISC - estratificação por riscos.............................................. 36

Quadro 2 - Graus de recomendações e níveis de evidência dos estudos terapêuticos em função do desenho de pesquisa.

Quadro 3 - Escala de avaliação de qualidade de estudos da área de controle de infecção cirúrgica.

Quadro 4 - Estratégia de busca usada para localizar os estudos nas bases eletrônicas. São Paulo, 2007.

Quadro 5 - Número de estudos encontrados, pré-selecionados, descartados e incluídos, segundo as bases de dados eletrônicas. São Paulo, 2007.

Quadro 6 - Estudos incluídos para revisão sistemática, segundo dados de publicação. São Paulo, 2007.

Quadro 7 - Distribuição dos estudos incluídos para revisão sistemática conforme os tipos de confecção dos aventais cirúrgicos reutilizáveis e descartáveis utilizados. São Paulo, 2007.

Quadro 8 - Recursos utilizados para analisar os desfechos das investigações dos estudos incluídos para revisão sistemática, conforme seus desfechos. São Paulo, 2007.

Quadro 9 - Distribuição dos estudos incluídos para revisão sistemática, conforme as variáveis extrínsecas controladas. São Paulo, 2007.

Quadro 10 - Distribuição dos estudos incluídos para revisão sistemática, conforme variáveis intrínsecas controladas. São Paulo, 2007.

Quadro 11 - Estudos incluídos para revisão sistemática conforme populações e quantidade de variáveis de risco controladas. São Paulo, 2007.

Quadro 12 - Evidência dos estudos incluídos conforme Escala de Avaliação de Qualidade de Estudos da Área de Controle de Infecção Cirúrgica (EQCIC). São Paulo, 2007.

Quadro 13 - Pontuação dos estudos randomizados incluídos para revisão sistemática, conforme Escala de Qualidade de Jadad. São Paulo, 2007

Quadro 14 - Evidências dos estudos incluídos para revisão sistemática, conforme as escalas de avaliação e os resultados da investigação. São Paulo, 2007.

Quadro 15 - Síntese panorâmica dos estudos incluídos para revisão sistemática, conforme escopo, método de investigação, resultado, avaliação EQCIC e JADAD. São Paulo, 2007.

Quadro I - Descritores indexados, classificados por intervenção, comparação e desfecho.

Quadro II - Descritores não indexados, classificados por intervenção, comparação e desfecho. 


\section{LISTA DE TABELAS}

Tabela 1 - Distribuição dos estudos incluídos para revisão sistemática conforme as variáveis submetidas à investigação. São Paulo, 2007.

Tabela 2 - Distribuição dos estudos incluídos para revisão sistemática, conforme os tipos de investigações. São Paulo, 2007.

Tabela 3 - Distribuição dos estudos incluídos para revisão sistemática, conforme os desfechos investigados. São Paulo, 2007.

Tabela 4 - Distribuição da freqüência de fatores risco extrínsecos controlados nos estudos incluídos para revisão sistemática, conforme os desfechos. São Paulo, 2007.....

Tabela 5 - Distribuição da freqüência de fatores de risco intrínsecos controlados nos estudos incluídos para revisão sistemática, conforme os desfechos. São Paulo, 2007.

Tabela 6 - Distribuição dos estudos incluídos para revisão sistemática, conforme análise de diferenças estatísticas das variáveis extrínsecas e intrínsecas entre os grupos controle e experimental. São Paulo, 2007. 


\section{SUMÁRIO}

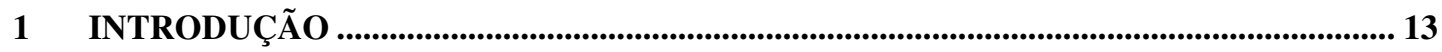

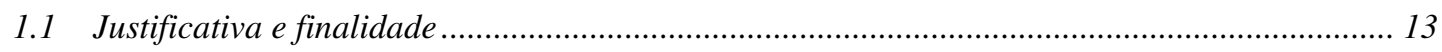

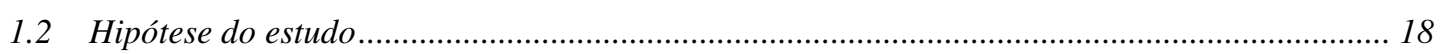

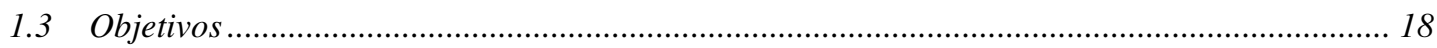

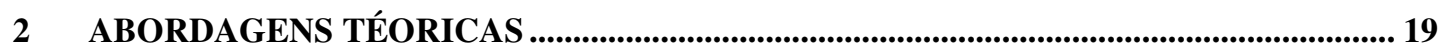

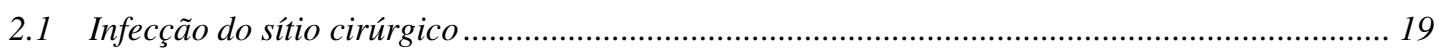

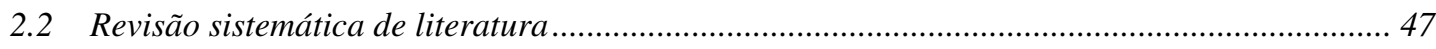

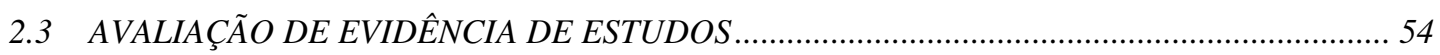

2.4 Problemática para avaliação de estudos da área de controle de infecção hospitalar. Uma

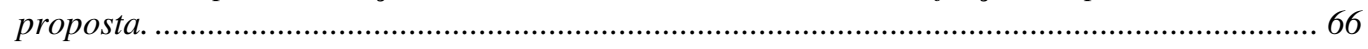

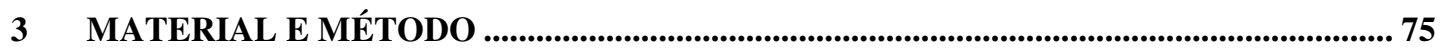

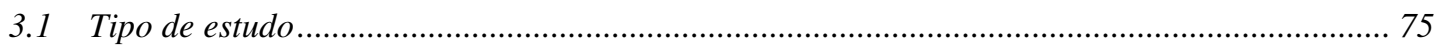

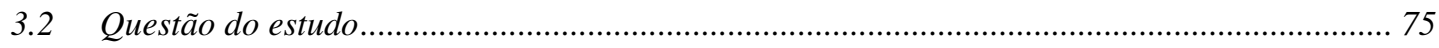

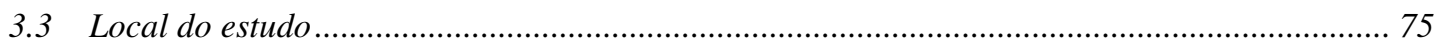

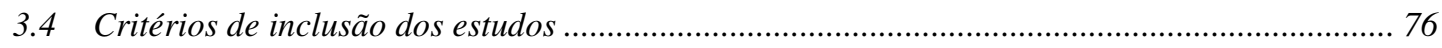

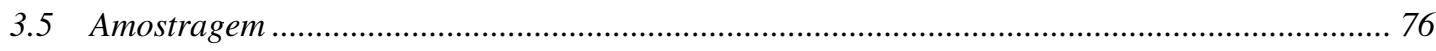

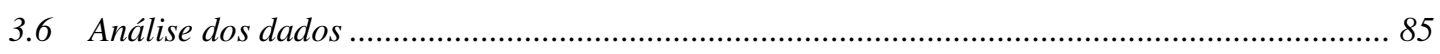

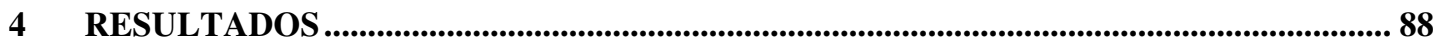

4.1 Caracterização do processo de seleção dos estudos encontrados na busca............................... 88

4.2 Caracterização dos estudos incluídos para revisão sistemática................................................. 90

4.3 Avaliação de qualidade e evidência dos estudos incluídos para revisão sistemática................. 103

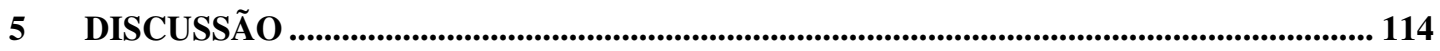

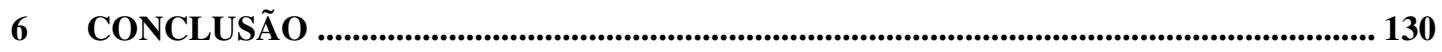

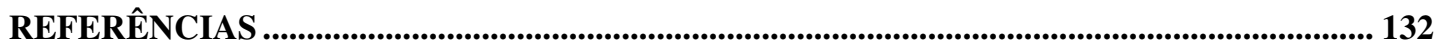

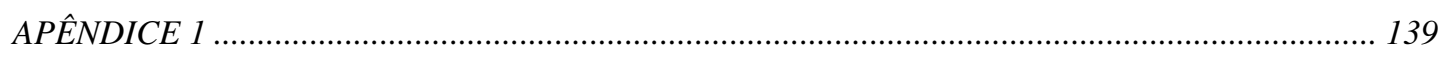

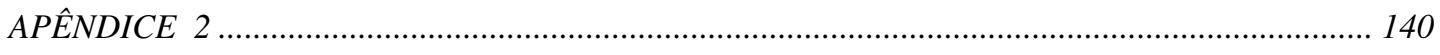

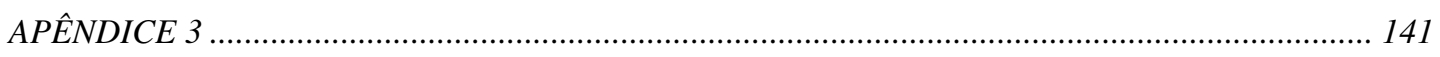

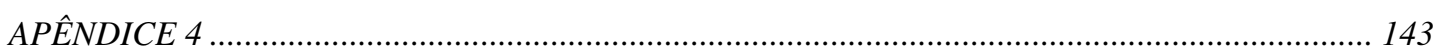




\section{INTRODUÇÃO}

\subsection{Justificativa e finalidade}

Apesar do avanço tecnológico na área de centro cirúrgico e do maior conhecimento sobre fatores de risco de infecção hospitalar, nas últimas décadas, as taxas de infecção do sítio cirúrgico (ISC) ainda são altas. Segundo registros do sistema de Vigilância Nacional de Infecção Hospitalar (National Nosocomial Infection Surveillance - NNIS) dos Estados Unidos, no período de 1986 a 1996, a ISC, nesse país, foi a mais comum entre os pacientes cirúrgicos, correspondendo a 38\% das infecções hospitalares (MANGRAM et al.,1999).

No Brasil, um estudo de prevalência sobre a magnitude de infecções hospitalares realizado pela Coordenação de Controle de Infecção Hospitalar do Ministério da Saúde, em noventa e nove hospitais terciários (100 a 299 leitos), situados nas Capitais Estaduais e no Distrito Federal, a infecção hospitalar mais comum foi a do trato respiratório inferior, que correspondeu a $29 \%$ do total, seguida pela do sítio cirúrgico, com 15,5\% (ASSOCIAÇÃO PAULISTA DE ESTUDOS E CONTROLE DE INFECÇÃO HOSPITALAR - APECIH, 1995).

Várias são as medidas de controle e prevenção de ISC recomendadas. As mais reconhecidas estão reunidas nas Diretrizes de Recomendações de Controle de Infecção do Sitio Cirúrgico do Centro de Controle e Prevenção de Doenças dos Estados Unidos (CDC), de 1999. Nelas, são considerados 
fatores de risco intrínsecos e extrínsecos. Os primeiros se relacionam ao paciente: idade, tipo de cirurgia, patologia de base, patologias associadas, entre outras. Os segundos se referem a procedimentos assistenciais: técnica cirúrgica, preparo préoperatório, ambiente, paramentação cirúrgica, antibioticoprofilaxia, entre outras (MANGRAM et al., 1999).

A paramentação cirúrgica, tradicionalmente, é constituída de gorro, máscara, luva esterilizada, óculos de proteção, propé, uniforme privativo, campos cirúrgicos e avental cirúrgico esterilizados. Seu intuito principal é prevenir a transferência de microrganismos da equipe cirúrgica e da própria pele do paciente para a ferida operatória e, conseqüentemente, reduzir o risco de sua contaminação e de ISC. Outro objetivo é proteger a equipe cirúrgica contra riscos ocupacionais, decorrentes de exposição ao sangue e a outros fluidos orgânicos do paciente, potencialmente contaminados com agentes infectantes, como HIV e Hepatites B e C (LACERDA, 2003; RABHAE, RIBEIRO FILHO, FERNANDES, 2000).

O avental cirúrgico, objeto desse estudo, constitui um dos principais componentes de barreira e é confeccionado com materiais de tecido e de não-tecido. O de tecido geralmente é reutilizável e o de não-tecido é de uso-único.

Há, atualmente, uma enorme variedade de materiais para confecção de aventais cirúrgicos, desde algodão, de diversas gramaturas, até lâminas totalmente sintéticas, o que vem dificultando aos profissionais a tomada de decisão na sua escolha, tanto com relação à sua eficácia enquanto barreira microbiológica, quanto ao seu custo-benefício. 
A Sociedade Norte-Americana de Enfermeiros do Centro Cirúrgico - AORN (2003) e a Norma Européia - EN13795-3 (2002) recomendam que os aventais cirúrgicos devam prover uma barreira apropriada contra microrganismos, sangue e outros fluidos corpóreos (seco ou molhado). Tais recomendações, no entanto, não definem o que consideram como "barreira apropriada".

Ao contrário do que ocorre com embalagens de produtos médicohospitalares, não há normas previamente definidas para a confecção de aventais cirúrgicos. No que se refere à capacidade de barreira microbiológica, temática desta investigação, os aventais de não-tecido apresentam enormes vantagens com relação aos de tecido. Uma delas é a segurança de sua aquisição sob a garantia de eficácia de seus fabricantes, a partir de testes previamente realizados. Incompreensivelmente, o mesmo rigor de qualidade não é exigido na aquisição dos aventais de tecido.

Outra vantagem do não-tecido reside no fato de que não há a preocupação de controle do seu desgaste, uma vez que são geralmente de uso-único. O contrário ocorre com os de tecido, pois mesmo constituídos com a melhor trama, sem dúvida vão perdendo paulatinamente sua capacidade de barreira com os diversos re-usos. Isto não quer dizer que não seja possível esse tipo de controle. Estudo de Rodrigues (2000), com embalagens duplas de tecido de algodão para artigos médicohospitalares, sarja T1, padronizado pela NBR 14028 da Associação Brasileira de Normas Técnicas (ABNT), demonstrou que essas embalagens permaneciam impermeáveis à penetração de bactérias até o $65^{\circ}$. reprocessamento. 
Por fim, o avental de não-tecido, quando garantido pelo fabricante, constitui, realmente, barreira antimicrobiana mais eficaz do que o de tecido, principalmente sob condições úmidas.

Há relatos, no entanto, de desconforto no uso de aventais de nãotecido, conforme seu material de confecção, particularmente no que se refere à mobilidade, aquecimento corporal e aumento da transpiração. Tais situações podem acrescer riscos ao paciente. De um lado, pela maior possibilidade de liberação da microbiota da pele, devido à transpiração mais intensa da equipe, e sua eliminação para áreas não totalmente protegidas pela paramentação cirúrgica. De outro, pela necessidade de diminuição da temperatura ambiental abaixo da normalmente recomendada, o que pode contribuir ainda mais para a hipotermia do paciente. Outra questão, que não pode deixar de ser abordada pela sociedade como um todo, é o impacto ambiental pelo uso intensivo de materiais pouco ou não degradáveis.

O impulso vertiginoso do uso de barreiras de não-tecido, inclusive aventais, ocorreu a partir da década de 80 do Século XX, com a maior conscientização dos riscos de transmissão de doenças ocupacionais infecciosas por contato com substâncias orgânicas dos pacientes, principalmente sangue. O que ainda não foi comprovado, porém, é se o uso de materiais de não-tecido realmente interfere, isoladamente, tanto na aquisição de doenças ocupacionais infecciosas, quanto na ocorrência de ISC.

Quanto às primeiras questões, estudo realizado em 2000, junto a 1535 trabalhadores de centros cirúrgicos de 88 hospitais do Brasil, obteve que as superfícies de maiores freqüências de contato com sangue foram: mão (52\%); rosto - 
somados olho, lábio, nariz e face (19\%) e membro superior (15\%). O tórax (2\%) e o abdômen (5\%) somados, regiões protegidas pelo avental, apresentaram freqüência tão baixa quanto pernas e pés (7\%). Na região dorsal, também protegida pelo avental, não foi relatado nenhum caso. Tais resultados também foram compatíveis com os de outras investigações internacionais, citadas nesse mesmo estudo (LACERDA, 2000). Além disto, em levantamento bibliográfico realizado por esta mesma autora, todos os casos de soro-conversão ocupacional para HIV ocorreram principalmente por contato percutâneo, seguido de mucoso. Nenhuma soro-conversão ocorreu por contato em pele íntegra. E, nos casos de contatos em centro cirúrgico, os percutâneos ocorreram quase sempre nos dedos das mãos, e os mucosos na face (LACERDA, 2000).

Com relação à ocorrência de ISC, não há consenso, entre vários estudos levantados por Garcia (2003), sobre diferença significativa de contaminação da ferida operatória e de ISC entre uso de aventais de tecido e de não-tecido. Isto porque as várias pesquisas existentes, que buscam essa conclusão, apresentam resultados contraditórios.

Tal situação suscitou a questionar a qualidade e a suficiência dessas pesquisas e motivou a realização da presente investigação, qual seja, realizar uma revisão sistemática da literatura em busca de evidências de repercussão na contaminação da ferida cirúrgica e ou de ocorrência ISC com o uso de aventais cirúrgicos de tecido e não-tecido, durante a realização de cirurgias.

Pretende-se, com isso, verificar se há evidências que fundamentem cientificamente a prática do uso de aventais em cirurgias, conforme seu material de 
confecção, ou concluir pela necessidade de realizar mais pesquisas, bem conduzidas metodologicamente, para esta tomada de decisão.

\section{$1.2 \quad$ Hipótese do estudo}

O avental cirúrgico de não-tecido constitui barreira antimicrobiana mais efetiva do que o avental de tecido reprocessável e, por isto, reflete na menor incidência e prevalência da contaminação e ou infecção do sítio cirúrgico.

\subsection{Objetivos}

\section{Geral}

Verificar se há evidências, pela revisão sistemática da literatura, que fundamentem cientificamente, a prática do uso de aventais em cirurgias, conforme seu material de confecção.

\section{Específicos}

- Selecionar estudos primários que investigaram o uso de aventais cirúrgicos no controle da contaminação e ou infecção do sítio cirúrgico, conforme o seu tipo de confecção;

- Analisar a qualidade metodológica destes estudos;

- Identificar evidências, nos resultados destes estudos, de diferenças de contaminação e ou infecção do sítio cirúrgico. 


\section{ABORDAGENS TÉORICAS}

\subsection{Infecção do sítio cirúrgico}

\subsubsection{Conceito}

Infecção hospitalar é qualquer infecção adquirida após a internação do paciente, que se manifesta durante a internação, após 72 horas da admissão hospitalar, ou mesmo após a alta, quando puder ser relacionada com a assistência hospitalar (MINISTÉRIO DA SAÚDE, 1998).

A infecção do sítio cirúrgico (ISC) é uma infecção hospitalar que se desenvolve no sítio submetido à intervenção cirúrgica. De uma forma geral, a ISC manifesta-se de 4 a 6 dias após o procedimento cirúrgico e no máximo até 30 dias, se não houve implante de material protético. Com material protético, a ISC pode ser diagnosticada até um ano após a cirurgia (RABHAE, RIBEIRO FILHO, FERNANDES, 2000).

\subsubsection{Classificação das infecções do sítio cirúrgico (ISC)}

A ISC é classificada, segundo sua profundidade, por critérios específicos. Um delas é a do Centro de Controle e Prevenção de Doenças (C.D.C.), em 1988 (GARNER et al.,1988), que as considera como superficiais e profundas. Outro critério foi estabelecido pela organização denominada Surgical Wound Task 
Force, em 1992, com representação das mais importantes sociedades americanas de controle de infecção, que classificou as ISC em incisionais superficiais, incisionais profundas e de órgão/ espaço (HORAN et al., 1992).

A infecção incisional superficial envolve somente pele ou tecido subcutâneo do local da incisão cirúrgica. Para seu diagnóstico, deve ocorrer pelo menos um dos seguintes achados: drenagem purulenta da incisão superficial com ou sem confirmação laboratorial; organismos isolados por meio de cultura obtida assepticamente do fluido ou tecido da incisão superficial; presença de pelo menos um dos seguintes sinais e sintomas: dor ou hipersensibilidade local, tumefação localizada, eritema, calor e infecção superficial; abertura da incisão deliberada pelo cirurgião e diagnóstico de ISC superficial realizado pelo cirurgião (MANGRAM et al.,1999).

Para notificar a infecção incisional profunda, que envolve tecidos moles profundos (fáscia e camadas musculares), deve ser encontrado pelo menos um dos seguintes achados: drenagem purulenta de origem profunda da incisão (mas não de órgão/espaço); deiscência espontânea ou abertura deliberada pelo cirurgião quando o paciente apresenta pelo menos um dos sinais ou sintomas: febre (maior que $38^{\circ} \mathrm{C}$ ), dor ou hipersensibilidade local, a não ser quando a cultura da incisão é negativa; presença de abcesso ou outra evidência de infecção em tecidos profundos, observada ao exame direto, durante reoperação, ou por exames histopatológicos ou radiológicos e diagnóstico de ISC profunda realizado pelo cirurgião (MANGRAM et al., 1999). 
A infecção de Órgão/Espaço envolve qualquer parte da anatomia (órgão ou cavidade) aberta ou manipulada durante o procedimento cirúrgico. Para o seu diagnóstico, deve ser observado pelo menos um dos achados seguintes: drenagem purulenta proveniente de dreno colocado dentro do órgão/espaço; organismos isolados através de culturas colhidas assepticamente de fluido ou tecido proveniente do órgão/espaço; presença de abscesso ou outra evidência de infecção envolvendo órgão/espaço pelo exame direto ou histopatológico ou radiológico ou durante reoperação e diagnóstico de ISC de órgão/espaço realizado pelo cirurgião (MANGRAM et al.,1999).

\subsubsection{Epidemiologia e etiologia da ISC}

Historicamente, a infecção, a dor e o sangramento, constituíam fatores limitantes do ato cirúrgico. Apesar dos avanços tecnológicos nos últimos 150 anos, o controle da dor e do sangramento foi mais efetivo que o da infecção. Só nos Estados Unidos, a ISC ocorre em 2\% a 5\% dos 16 milhões de pacientes que são submetidos a procedimentos cirúrgicos anualmente, aumentando a hospitalização, em média, 7,4 dias, e os custos hospitalares em até 10 bilhões de dólares (WONG, 1999).

As condições necessárias para o desenvolvimento de uma ISC são o reservatório ou fonte de microrganismos, o seu modo de transmissão (veiculação dos germes), a incisão cirúrgica, onde os organismos são depositados, e a susceptibilidade do paciente. Embora, nem sempre seja possível identificar a origem dos microrganismos que causam ISC, parece haver consenso, pela grande maioria 
dos estudiosos de infecção hospitalar, de que as principais fontes de microrganismos, em ordem de importância, são: $1^{\mathrm{o}}$.) O próprio paciente; $2^{\circ}$.) A equipe cirúrgica; $3^{\circ}$.) Os objetos e superfícies inanimados; $4^{\circ}$.) $\mathrm{O}$ ar ambiente (RABHAE, RIBEIRO FILHO, FERNANDES, 2000; FERNANDES, RIBEIRO FILHO, BARROCO, 2000).

Com relação ao paciente, a fonte principal é a inoculação direta a partir da sua própria microbiota, principalmente da pele e tratos gastrintestinal, urinário, respiratório e genital feminino, por ocasião de sua abertura e manipulação. As fossas nasais do paciente também podem ser fontes de ISC por S. aureus, em cirurgias próximas à cabeça. Focos infecciosos distantes também atuam como reservatórios de microrganismos a partir do paciente que, em decorrência do estresse cirúrgico, podem se disseminar através das vias hemática e linfática (RABHAE, RIBEIRO FILHO, FERNANDES, 2000).

Aproximadamente $40 \%$ dos profissionais que participam do ato cirúrgico são portadores nasais deste germe e 12\% o apresentam no períneo (WONG, 1999). Entretanto, nem todos os portadores eliminam este microrganismo, mas patologias descamativas e quadros secretantes das vias aéreas facilitam a disseminação; porém somente em casos de surto por esse agente é recomendada pesquisa dos portadores (RABHAE, RIBEIRO FILHO, FERNANDES, 2000).

Substâncias, artigos e equipamentos que entram em contato direto com o sítio cirúrgico podem constituir fontes quando não forem devidamente esterilizados e manipulados. 
O ambiente, por si só, não parece estar relacionado com a contaminação da ferida e o desenvolvimento de ISC, exceto de forma indireta, como veículo de microrganismos liberados de suas fontes e ou reservatórios, tais como ar condicionado, equipe, etc.

Dentre as formas de transmissão de infecção hospitalar, citadas por Garner (1996) - contato, gotículas, aerossóis, veiculação e vetores, Lacerda (2003) considera que o contato é, sem dúvida, a principal em centro cirúrgico, seja diretamente - pele com pele, seja indiretamente - instrumentos, ambientes, superfícies, descamação da pele, etc.

Uma vez ocorrida contaminação, o desenvolvimento de infecção vai depender de muitos aspectos, mas principalmente da quantidade do agente inoculado e da sua virulência, além da capacidade de defesa do hospedeiro. O microrganismo tem papel passivo na transmissão, pois ele utiliza o rompimento das barreiras anti-infecciosas e sua penetração durante o ato cirúrgico. Assim, as medidas de controle devem visar primeiramente ao paciente e à equipe, não despendendo esforços centrados no microrganismo, a não ser em casos de elucidação da cadeia epidemiológica de determinados surtos (RABHAE, RIBEIRO FILHO, FERNANDES, 2000).

Staphylococcus coagulase negativo e $S$. aureus são os principais microrganismos causadores de ISC, oriundos principalmente da pele, mas também ocasionalmente da cavidade nasal e do períneo de pacientes e profissionais. Os cocos Gram-positivos são relativamente mais isolados em cirurgias limpas, e as bactérias Gram-negativas aeróbicas e anaeróbicas são mais comuns após procedimentos 
contaminados ou potencialmente contaminados. O Staphylococcus coagulase negativo é um importante agente em cirurgias com material protético. Estreptococcus, Bacteroides (outros que não B. fragilis), Fusobacterium e Peptostreptococci são isolados em cirurgias da cavidade oral e do esôfago. Além desses agentes, têm importância as enterobactérias em cirurgias do estômago. Esses mesmos microrganismos, além dos Enterococcus, B. fragilis e Clostridium, são encontrados em cirurgias ginecológicas, trato biliar, íleo distal e cólon. Em procedimentos cirúrgicos urológicos os estreptococos e os bacilos Gram-negativos são relevantes. Os fungos, principalmente a Cândida spp, são cada vez mais isolados, ao lado de bacilos Gram-negativos não fermentadores, como Acinetobacter $e$ Burkholderia cepacia (RABHAE, RIBEIRO FILHO, FERNANDES, 2000).

O aumento das ISC causadas por cepas resistentes, tanto Gramnegativas quanto Gram-positivas, constitui uma grande preocupação. Assim também as ISC envolvendo fungos, especialmente Cândida albicans ou C. tropicalis, devido, principalmente, ao aumento de cirurgias em pacientes com deficiência imunológica. As ISC causadas por microrganismos não usuais também têm aumentado, por exemplo: Rhizopus rhizopodiformis, por contaminação de curativos; Mycobacterium chelonei e M. fortuitum, pelo aumento das mamoplastias; Rhodococcus bronchialis, em feridas do esterno após a colocação de marcapasso da artéria coronária; ISC e endocardite na colocação de próteses valvulares, por Legionella pneumophila após contaminação pela água de torneira. Tais ocorrências por microrganismos não usuais, de microbiota exógena, exigem investigação para estabelecer medidas de controle e prevenção de fontes comuns (WONG, 1999). 


\subsubsection{Fatores predisponentes para ISC}

Podemos classificar os fatores que predispõem à ISC naqueles relacionados aos microrganismos, aos pacientes, aos procedimentos cirúrgicos e ao ambiente (RABHAE, RIBEIRO FILHO, FERNANDES, 2000).

\section{Fatores relacionados ao microrganismo}

A maior quantidade de microrganismos em um dado sítio determina maior probabilidade de ocorrência de infecção ou, quanto menor a chance de uma bactéria chegar à incisão cirúrgica, menor será a probabilidade de haver complicação infecciosa. Em experimentos animais, determina-se que a dose infectante crítica seja $10^{6}$ bactérias por grama de tecido, com inóculos menores não causando infecção (TCHERVENKOS, MEAKINS, 1995). A virulência do microrganismo também está relacionada com maior risco de infecção, mais do que a quantidade do inóculo. Assim, não são comuns bactérias anaeróbicas causarem infecção em pacientes sem deficiência de resposta imune. A penetração de $10^{7}$ UFC de E. coli em feridas pode causar septicemia e óbito; já, $10^{8}$ de Bacteroides fragilis não causa morte. Características dos próprios microrganismos, como presença de cápsula, capacidade de produzir determinadas enzimas e fatores de aderência ao tecido, os tornam mais aptos a desenvolver quadro infeccioso. Assim, cepas de $S$. aureus que apresentam cápsulas causam experimentalmente mais infecções do que cepas que não a possuem (RABHAE, RIBEIRO FILHO, FERNANDES, 2000). 
Dentre os fatores de risco relacionados ao paciente destacam-se os extremos de idade (idosos ou crianças). A causa principal seria a imunodeficiência. Porém, segundo os estudos sintetizados por Rabhae, Ribeiro Filho, Fernandes (2000) não são totalmente concordantes. A idade, então, teria apenas valor moderado.

Pacientes com múltiplas doenças pré-existentes têm maior probabilidade de contrair infecção, podendo ser demonstrado pela estratificação de pacientes com a classificação ASA. Pacientes com ASA classes III, IV e V apresentam, estatisticamente, incidência maior de infecção. Não há qualquer indício de que a incidência de infecção possa ser alterada devido à raça, apesar dos dados escassos sobre o assunto (RABHAE, RIBEIRO FILHO, FERNANDES, 2000).

Infecções em outros órgãos fora do sítio cirúrgico também constituem fator de risco, independente de qualquer outro fator, por poder favorecer bacteremia no pós-operatório imediato e causar contaminação da ferida (RABHAE, RIBEIRO FILHO, FERNANDES, 2000).

A Diabetes mellitus é um fator de risco importante, devido a alterações da cicatrização, complicações vasculares e neuropáticas e diminuição dos mecanismos de defesa que esta doença acarreta. A hiperglicemia pode afetar os linfócitos e determinar defeitos na resposta quimiotáxica, aderência e função fagocítica de neutrófilos (VAN DE MEER, 1986).

A obesidade também é um fator de risco, tendo a espessura do tecido gorduroso influências direta e proporcional nas taxas de infecção e as razões para esta susceptibilidade parecem ser a irrigação local do tecido adiposo, que é comprovadamente pouco vascularizado, associada à maior duração dos 
procedimentos cirúrgicos e ao trauma da parede abdominal. Além disso, a área exposta do paciente obeso à contaminação é bem maior, com possível formação de espaços mortos e a utilização de sutura subcutânea para fechá-los (RABHAE, RIBEIRO FILHO, FERNANDES, 2000).

O tabagismo é outra característica que oferece risco, considerado pelas Diretrizes de Controle e Prevenção de Infecção do CDC (MANGRAM et al., 1999).

A desnutrição pode diminuir a função fagocítica, os níveis de complemento e de anticorpos, reduzir a reação de linfócitos a mitógenos e afetar a resposta de imunidade celular tardia. O uso de nutrição parenteral ou enteral poderá reduzir o risco de infecção cirúrgica, por melhorar as defesas naturais do hospedeiro (MOORE et al., 1989).

\section{Fatores relacionados ao procedimento cirúrgico}

Aqui, são considerados tempo de internação antes da cirurgia, técnica cirúrgica, procedimentos de preparo pré-operatório do paciente, uso de antibioticoprofilaxia, paramentação cirúrgica, tipo de cirurgia, ar ambiente, entre outros.

O tempo de internação antes da cirurgia tem sido tradicionalmente considerado importante fator de risco. A colonização do paciente com a microbiota hospitalar aumenta proporcionalmente ao tempo de hospitalização, especialmente com bacilos Gram-negativos aeróbicos. No entanto, estudos disponíveis ainda não 
apresentam evidência científica dessa relação (RABHAE, RIBEIRO FILHO, FERNANDES, 2000).

A técnica cirúrgica é de grande importância para o desenvolvimento de condições favoráveis à proliferação de germes ou contaminação do campo operatório, principalmente, à manipulação dos tecidos, extensão e duração da cirurgia. A associação tempo de cirurgia e risco intrínseco de infecção talvez seja uma das relações mais fortes no que diz respeito ao valor preditivo de ISC (RABHAE, RIBEIRO FILHO, FERNANDES, 2000).

O preparo pré-operatório do paciente implica desde avaliação de riscos intrínsecos do paciente, tricotomia, banho pré-operatório e anti-sepsia da pele. Outros procedimentos pré-operatórios se referem à degermação e paramentação cirúrgica (RABHAE, RIBEIRO FILHO, FERNANDES, 2000).

O instrumental cirúrgico pode ser uma fonte de contaminação quando, mesmo tendo sido esterilizado por método correto, a embalagem sofrer violação ou se durante sua manipulação no ato cirúrgico for tocado por algum objeto contaminado. Ele também pode se contaminar com microrganismos do ambiente e ao ser utilizado em tecidos colonizados do próprio paciente e, em seguida, entrarem em contato com seus tecidos isentos (RABHAE, RIBEIRO FILHO, FERNANDES, 2000).

A transfusão de sangue, em especial de concentrado de hemácias, é um fator de risco independente para infecção. É menor quando se transfunde sangue autólogo e pode aumentar conforme a quantidade de unidades de sangue administradas (HEISS, MEMPEL, JAUCH, 1993; VERWAAL, WOBBES, 
KOOPMAN VAN GERMET, 1992). O tipo de cirurgia também está relacionado com maior ou menor incidência de ISC e diz respeito ao potencial de contaminação, extensão e duração da cirurgia. É controverso o quanto interfere no risco de complicação infecciosa a realização de múltiplos procedimentos cirúrgicos concomitantemente. Talvez o prolongamento da cirurgia seja o real fator de aumento de risco de infecção (KLUYTMANS, 1997).

O ar ambiente, conforme já citado anteriormente, não é considerado, por si só, fator predisponente de ISC. Ele atua antes como veículo, pela liberação de microrganismos presentes em outras fontes, como ar condicionado e outros equipamentos e pele da equipe. Mas, por isto mesmo, são necessários mecanismos que diminuam a concentração no ar desses microrganismos, de maneira a evitar seu contato, por queda gravitacional, com o sítio cirúrgico aberto (SIQUEIRA, 2000).

\subsubsection{Medidas de controle e prevenção de ISC}

As medidas de controle e prevenção de ISC, mais largamente difundidas, encontram-se nas Diretrizes de Controle e Prevenção de Infecção do Sítio Cirúrgico do Centro de Controle e Prevenção de Doenças (C.D.C.), dos Estados Unidos. As recomendações para cada situação ou procedimento são estabelecidas conforme as categorias (MANGRAM et al., 1999):

- IA: fortemente recomendada para implementação, tendo como suporte estudos clínicos experimentais e epidemiológicos bem desenhados. 
- IB: fortemente recomendada para implementação, tendo como suporte alguns estudos experimentais clínicos e epidemiológicos, assim como forte razão teórica.

- II: sugerido para implementação, tendo como suporte estudos clínicos e epidemiológicos ou razões teóricas.

- NR (não recomendado), NR (não resolvido): práticas para as quais não há insuficiência de evidência ou não há consenso de eficácia.

São citadas, a seguir, as recomendações de melhores categorias de evidência (IA e IB), dessas diretrizes:

\section{A - Preparo pré-operatório}

- Glicemia < 200mg no intra-operatório e pós-operatório imediato (48h) - IB

- Abstenção do tabaco um mês antes da cirurgia eletiva - IB

- Identificar e tratar infecções remotas do sítio cirúrgico, não realizando procedimentos eletivos em pacientes com essas infecções - IA

- Prescrever banho pré-operatório do paciente com agente antiséptico, na noite anterior e na manhã do ato cirúrgico - IB 
- Não remover os pêlos, exceto ao redor da incisão e quando interferir no ato cirúrgico - IA

- Quando a tricotomia estiver indicada deve ser realizada imediatamente antes do ato cirúrgico e preferir tricotomizadores ao emprego de lâminas ou cremes depiladores - IA

- Limpeza com água corrente e agente tensoativo ao redor do local onde será praticada a incisão, para promover a remoção da contaminação grosseira - IB

- Aplicar um agente anti-séptico (álcool 70-92\%; clorexidina 2$4 \%$ aquosa ou $0,5 \%$ alcoólica; iodóforos $10 \%$ ) em movimentos circulares centrífugos, a partir do local da incisão principal e secundárias - IB

\section{B - Anti-sepsia pré-operatória da equipe cirúrgica}

- Manter as unhas rentes e não utilizar unhas artificiais - IB

- O preparo das mãos da equipe deve ser realizado antes de se tocar o campo e instrumentais esterilizados ou a própria pele preparada do paciente. Deve iniciar com a limpeza de cada leito subungueal; envolver as mãos até acima do cotovelo; durar de 3 a 5 minutos, com o emprego de um anti-séptico apropriado. Após sua realização as mãos devem ser mantidas para cima, 
com os cotovelos flexionados, para que a água escoe para o cotovelo. A secagem deve ser realizada com toalha estéril - IB

\section{C - $\underline{\text { Antibioticoprofilaxia }}$}

- Selecionar o antibiótico com base na sua eficácia contra os microrganismos que mais freqüentemente causam infecção do sítio cirúrgico, de acordo com o procedimento - IA

- Administrar o antimicrobiano por via endovenosa, exceto em procedimentos colo-retais, nos quais pode ser empregado por via oral - IA

- Administrar o antimicrobiano antes do início da cirurgia, idealmente 30 minutos, mais não mais do que 2 horas, para que ele atinja níveis tissulares quando a incisão for praticada - IA

- Não estender a profilaxia no período pós-operatório - IB

- Empregar reforço no período intra-operatório quando a cirurgia ultrapassar a meia-vida estimada da droga; ocorrer grande perda sanguínea; pacientes com obesidade mórbida - IB

- Não é recomendado o uso rotineiro de vancomicina na antibioticoprofilaxia - IB 
D - Ventilação da sala cirúrgica

- Manter pressão positiva na sala cirúrgica em relação ao corredor e áreas adjacentes - IB

- Manter um mínimo de 15 trocas por hora, das quais pelo menos três sejam de ar fresco - IB

- Filtrar o ar fresco ou recirculado de acordo com as recomendações oficiais - IB

- Introduzir o ar pelo teto e realizar sua exaustão próximo ao solo - IB

- Manter as portas fechadas, exceto para passagem de equipamentos, pessoal e pacientes - IB

- Limitar o número de presentes, ao pessoal necessário - IB

E - Limpeza e desinfecção de superfícies fixas

- Aplicar um desinfetante aprovado, antes de um novo procedimento cirúrgico, para uma descontaminação de superfícies fixas ou equipamentos que tiveram contato com sangue ou outro fluido corpóreo durante a cirurgia - IB

- Aplicar diariamente no piso da sala cirúrgica após o último procedimento, um desinfetante aprovado - IB 
- Não há necessidade de procedimentos especiais de limpeza e desinfecção após procedimentos contaminados ou infectados IA

- Não se deve utilizar capacho impregnado com desinfetante na entrada do Centro Cirúrgico, pois não contribui para reduções de infecções - IA

\section{F - Esterilização do instrumental cirúrgico}

- Esterilizar todo instrumental cirúrgico - IB

- Realizar a esterilização rápida apenas em situações de emergência, não sendo indicada rotineiramente para o reprocessamento de material - IB

$\mathrm{G}-\underline{\text { Anestesia }}$

- A equipe anestésica deve aderir às práticas recomendadas para o controle de infecção durante a cirurgia - IA

\section{H - Técnica cirúrgica}

- Manipular os tecidos delicadamente, promovendo uma hemóstase efetiva, minimizando tecidos desvitalizados e corpos estranhos e eliminação de espaços mortos no sítio cirúrgico - IB 
- Se o sítio cirúrgico estiver grosseiramente contaminado deve-se optar por manter a incisão aberta, promovendo uma cicatrização por segunda intenção - IB

- Quando a drenagem for necessária, utilizar sistemas fechados, exteriorizados por local distinto da incisão principal, removendo os drenos tão logo quanto possível - IB

\section{I - $\underline{\text { Cuidados com a incisão cirúrgica pós-operatória }}$}

- Proteger a incisão fechada primariamente com curativo estéril por 24-48 horas, assegurando que ele permaneça seco e não seja removido durante o banho - IA

- Lavar as mãos com anti-séptico antes e depois da realização do curativo ou ao tocar a incisão cirúrgica - IA

\section{J - Paramentação cirúrgica}

- Trocar a paramentação quando estiver visivelmente suja com sangue ou outro fluido corpóreo potencialmente infectante - IB

- A máscara cirúrgica deve cobrir totalmente a boca e o nariz, e deve ser utilizada ao entrar na sala cirúrgica se o instrumental estiver exposto ou a cirurgia estiver em andamento - IB

- Todo cabelo e barba devem estar cobertos ao entrar na sala cirúrgica - IB 
- Não utilizar propés com a finalidade exclusiva de evitar infecção do sítio cirúrgico - IA

- As luvas esterilizadas devem ser calçadas após a colocação do avental cirúrgico - IB

- Os materiais empregados na confecção do avental cirúrgico devem assegurar uma barreira efetiva, mesmo quando umedecidos - IB

Mangram et al. (1999) citam, ainda, três categorias de variáveis que têm sido bastante consideradas como índice preditivo de risco de ISC: potencial de contaminação da cirurgia, duração da cirurgia e susceptibilidade do paciente. $\mathrm{O}$ potencial diz respeito às quatro classificações conhecidas - limpa, limpacontaminada, contaminada, suja ou infectada. Quanto à duração, o risco aumenta a cada 2 horas de cirurgia. Com relação à susceptibilidade do paciente considera-se a classificação ASA, originalmente estabelecida pelos anestesiologistas. Este índice de risco varia de 0 a 3, conforme Quadro abaixo.

Quadro 1 - Modelo preditivo de ISC - estratificação por riscos.

\begin{tabular}{|l|l|l|l|}
\hline Tempo cirúrgico & Menor que 2 $=0$ & Maior que 2 =1 & 0 a 1 \\
\hline ASA & ASA 1 e 2 0 & ASA 3 e 4 =1 & 0 a 1 \\
\hline $\begin{array}{l}\text { Potencial de } \\
\text { contaminação }\end{array}$ & $\begin{array}{l}\text { Limpa ou potencialmente } \\
\text { contaminada }=0\end{array}$ & Contaminada ou infectada =1 & 0 a 1 \\
\hline Risco cirúrgico & Somatória & Somatória & 0 a 3 \\
\hline
\end{tabular}




\subsubsection{Paramentação cirúrgica e controle de infecção do sítio cirúrgico}

A paramentação cirúrgica constitui um vestuário específico de centro cirúrgico, sendo tradicionalmente composta de uniforme privativo (calça e blusa), propé ou sapato privativo, gorro, máscara buco-nasal (ou facial cirúrgica), avental cirúrgico, luva cirúrgica e campos cirúrgicos. Sua finalidade original é estabelecer uma barreira microbiológica contra a penetração de microrganismos no sítio cirúrgico do paciente, oriundos dele mesmo, dos profissionais, materiais, equipamentos e ar ambiente. Com o advento da AIDS e o reconhecimento de riscos de contato ocupacional e de aquisição dessa e outras doenças transmissíveis por substâncias orgânicas dos pacientes, a importância dessa barreira ganhou nova dimensão, no sentido de proteger também o profissional, e adicionou os óculos ou máscaras com protetores de olhos aos componentes tradicionais da paramentação cirúrgica (PAZ et al., 2000; MONTEIRO et al., 2000).

Segundo Lacerda (2003), a relação entre a transmissão de infecção e uso de barreiras em centro cirúrgico ainda apresenta resultados não conclusivos e contraditórios, nos diversos estudos já realizados. Os motivos podem ser buscados na aplicação de metodologias inadequadas ou na dificuldade de controlar as inúmeras variáveis envolvidas na ocorrência de infecção hospitalar, conforme já citadas anteriormente.

Havendo, porém, reconhecimento de que a transmissão de ISC ocorre predominantemente por contato e que as fontes principais de microrganismos que causam ISC originam-se do paciente e dos profissionais, esta autora considera 
que não há como duvidar sobre a importância do uso de barreiras que evitem a transferência de microrganismos dessas fontes para a ferida cirúrgica.

Sendo assim, o uso de técnicas de assepsia e de barreiras antimicrobianas é altamente justificado durante cirurgias, e corroboradas por recomendações de vários estudiosos e associações de profissionais.

Conforme é possível observar no item anterior, as medidas de controle e prevenção de ISC, referentes à paramentação cirúrgica, inserem-se quase todas na categoria IB e elas dizem mais respeito às condições para seu uso. Somente seu último item refere-se à utilização de materiais de confecção do avental cirúrgico, que assegurem uma barreira microbiológica, mesmo em condições úmidas. Mas, os critérios para determinação dessa barreira não são explicitados.

Embora, nos últimos anos, a preocupação da prática assistencial e dos estudos científicos voltam-se predominantemente para o tipo de material de barreira, principalmente dos aventais, máscaras e óculos, Lacerda (2003) considera que isto não é suficiente se não for acatado o seu uso apropriado, o que inclui desde a técnica e o momento de sua colocação, até o modelo e o tamanho, garantindo cobertura completa da região a que se destina. A autora considera, ainda, que por constituir uma barreira mecânica, a função primordial da paramentação cirúrgica corresponde ao momento da cirurgia, com destaque para o uso do avental cirúrgico. 


\subsubsection{Avental cirúrgico enquanto componente da paramentação cirúrgica}

Conforme já citado, o avental cirúrgico é um dos constituintes da paramentação cirúrgica. Deve ser esterilizado e utilizado apenas pelos profissionais que participam diretamente do ato operatório: cirurgiões e instrumentadores. Ele é vestido com técnica asséptica, dentro da sala de operações, após a colocação de máscara, óculos de proteção e realização da degermação.

Junto com as luvas cirúrgicas, o avental constitui barreira fundamental contra a liberação de microrganismos da pele da equipe e sua transferência direta para o campo operatório, incluindo a ferida cirúrgica. Pelo mesmo motivo, também protege a equipe cirúrgica contra os riscos ocupacionais, referentes à exposição ao sangue e a outros fluidos orgânicos oriundos do paciente, principalmente do vírus do HIV, Hepatite B e Hepatite C (RUTALA, WEBER, 2001).

Os materiais de fabricação dos componentes da paramentação e de outras barreiras microbianas têm sido objeto de inúmeras investigações para sua melhor qualificação, não apenas para o controle de contaminação do paciente, mas também para a prevenção de contato ocupacional com sangue e outras substâncias orgânicas (ARHMAD, SHERMAN, HAGGLUND, 1998; INDA, 1993; AORN, 1995; BELKIN, 1999; BELKIN, 2000; BELKIN, 2002; LANKESTER et. al, 2002; MC CULLOUGH, 1993; LACERDA, 2000; KOCH, JAMES, 1995; RUTALA, WEBER, 2001). 
Incluem-se, nesta qualificação, a discussão sobre a necessidade ou não de total impermeabilidade desses componentes a fluidos orgânicos e se eles devem ser de uso-único ou reutilizáveis. Apesar da ampla discussão dos últimos anos, ainda não há normas técnicas oficialmente estabelecidas para qualificar esses componentes no Brasil.

Desde o século XIX até os dias atuais, tecidos são utilizados nas salas de operações. Na década de 50, foi introduzida a musselina, 100\% algodão, conhecido como barreira T140, por apresentar 140 fios $/ \mathrm{pol}^{2}$. Esse tecido era leve, absorvente e extremamente poroso. Na década de 60 foi empregado tecido misto, composto de $50 \%$ algodão e $50 \%$ poliéster, conhecido como barreira T-180, por conter 180 fios $/ \mathrm{pol}^{2}$, com uma distância entre os fios de $75 \mu \mathrm{m}$. E na década de 70 foi introduzido um campo de 100\% algodão T-280, denominado Quarpel, com 280 fios/pol ${ }^{2}$, finalizado com um produto à base de fluorcarbono (STANEWICK, KOGUT, 1993).

Observa-se, portanto, que ocorreu aumento do número de fios dos tecidos e uma diminuição do espaço entre eles, entre as décadas de 50-70, com objetivo de obter uma barreira microbiana mais eficaz. Entretanto, tecido com grande quantidade de fios dificulta, e mesmo impede, em alguns casos, a passagem do vapor durante esterilização em autoclave.

Na década de 80 foi introduzido um tecido de 50\% algodão e 50\% poliéster T-175, com espaço entre os fios menor que $1 \mu \mathrm{m}$, sendo finalizado à base de fluorcarbono, produto que funciona como repelente químico à penetração da água. 
Repetidos reprocessamentos (lavagens e esterilizações), porém, diminuem esta capacidade (STANEWICK, KOGUT, 1993).

Conforme a ABNT/TB 392, apud Rodrigues (2000), tecido é uma estrutura produzida pelo entrelaçamento de um conjunto de fios de urdume (fios dispostos na direção longitudinal do tecido) e um conjunto de fios de trama (fios dispostos na direção transversal do tecido), formando um ângulo de ou próximo de $90^{\circ}$

De acordo com a Associação Brasileira de Indústrias de Nãotecidos e Tecidos Técnicos (ABINT), na década de 60 do século XX ocorreu o lançamento de material de não-tecido como matéria-prima industrial e como produto de consumo. E na década de 70 houve ascensão da indústria de não-tecido, principalmente sob novas tecnologias de processo (ABINT, 2007).

O não-tecido, segundo a Norma NBR 13370 (2002), é definido como uma estrutura plana, flexível e porosa, formada por uma ou mais camadas de véus de fibras ou filamentos, pré-direcionados ou ao acaso, obtidos por processos distintos: via seca, aérea, úmida ou fundida.

A ABINT (2007) oferece informações mais detalhadas sobre esses materiais e sua confecção, conforme segue.

Os não-tecidos, basicamente, podem ser classificados quanto a: gramatura, processo de fabricação, consolidação, transformação e/ou conversão, matéria-prima, características das fibras/filamentos, ou associação desses elementos. 
Quanto à gramatura (peso por unidade de área), são classificados em: Leve, menor que $25 \mathrm{~g} / \mathrm{m} 2$; Médio, entre 26 e 70 g/m2; Pesado, entre 71 e 150 $\mathrm{g} / \mathrm{m} 2$; Muito pesado, acima de $150 \mathrm{~g} / \mathrm{m} 2$.

Quanto à formação da manta (web forming), estrutura ainda não consolidada, ela é formada por uma ou mais camadas de véus de fibras ou filamentos obtidos por três processos distintos: Via Seca; Via Úmida; Via Fundida.

Nos processos de Via Seca, são incluídos os não-tecidos produzidos Via Carda (Carded) e Via Aérea/Fluxo de ar (Air Laid). No primeiro, as fibras são dispostas paralelamente por cilindros recobertos de "dentes penteadores", que formam mantas anisotrópicas, podendo essas mantas às vezes ser cruzadas em camadas. No segundo, as fibras são suspensas em fluxo de ar e depois são coletadas numa tela formando a manta. Esses processos ocorrem com matérias-primas na forma de fibras.

O processo Via Úmida (Wet Laid) também trabalha com matériasprimas na forma de fibras, as quais são suspensas em meio aquoso e depois coletadas através de filtração por um anteparo, em forma de manta.

No processo Via Fundida são incluídos os não-tecidos produzidos Via Extrusão, que são os de fiação contínua (Spunweb / Spunbonded) e por Via Sopro (Meltblown). Esses processos trabalham com matéria-prima na forma de polímeros (materiais plásticos). No processo Spunweb / Spunbonded, um polímero termoplástico é fundido através de uma "fieira", resfriado e estirado, e posteriormente é depositado sobre uma esteira em forma de véu ou manta. No processo Meltblown um polímero termoplástico é fundido através de uma "fieira" 
com orifícios muito pequenos, e imediatamente um fluxo de ar quente rapidamente solidifica a massa em fibras muito finas, que são sopradas em alta velocidade para uma tela coletora, formando a manta.

Existem outros processos particulares de fabricação/formação da manta, mas aqueles citados acima representam o grande volume dos não-tecidos.

Após a formação do véu ou da manta (Wet Bonding) é necessário realizar a consolidação (união das fibras ou filamentos), que em grande parte também dão o acabamento necessário para o produto final. Existem três métodos básicos para consolidação/acabamento de não-tecidos, que também podem ser combinados entre si: Mecânico (fricção); Químico (adesão); Térmico (coesão).

O método mecânico apresenta três formas: a) Agulhagem (Needlepunched), onde as fibras ou filamentos são entrelaçados através da penetração alternada de muitas agulhas que possuem saliências / barbelas; b) Hidroentrelaçamento (Spunlaced ou Hydroentangled), onde o entrelaçamento das fibras ou filamentos é feito pela penetração na manta de jatos d'água a altas pressões; c) Costura (Stitchbonded), através da inserção de fios de costura na manta ou processo sem fios, que trabalha com as próprias fibras do não-tecido para realizar a costura.

No método químico-resinagem (Resin Bonded), os ligantes químicos (resinas) realizam a união das fibras ou filamentos do não-tecido. 
No método térmico-termoligado (Thermobonded), as ligações das fibras ou filamentos do não-tecido são realizadas pela ação de calor, através da fusão das próprias fibras ou filamentos.

Quanto à transformação, acabamento e ou conversão do não-tecido (Fabric Finishing/Converting), eles são fornecidos normalmente em grandes rolos e chamados internacionalmente de "Roll Good", podendo sofrer processo posterior de transformação ou conversão. Pode-se utilizar vários tipos de transformação, acabamento e/ou conversão: corte em menores larguras e peças, confecção, dublagem, impregnação, cobertura, adesivagem, tingimento, estampagem, impressão, chamuscagem, laminação, dentre outras; inclusive alguns processos de consolidação que foram mencionados (agulhagem, calandragem, resinagem, costura e outros).

Quanto às matérias-primas, as fibras/filamentos são predominantes na fabricação dos não-tecidos. Sua proporção nos produtos finais varia de 30 a $100 \%$. É sempre indispensável as indicações nominal e porcentual da composição de suas matérias-primas constituintes. As propriedades das fibras/filamentos somadas às fornecidas pelo processo de fabricação/consolidação/transformação definem as características finais dos não-tecidos e também seu desempenho. As matérias-primas das fibras / filamentos mais utilizadas são:

- Artificiais: Viscose, Vidro, Silicone, Acetato;

- Naturais: Lã, Algodão, Coco, Sisal, Cashmere, Asbesto, Metálicas (níquel-cromo, césio-cromo) e cerâmicas; 
- Sintéticas: Poliéster, Polipropileno, Poliamida (nylon), Poliacrilonitrita (Acrílico), Polietileno, Policarbonato. Os ligantes (resinas) são produtos químicos usados para consolidação, transformação e acabamento dos não-tecidos.

- Dispersões Poliméricas: látex sintético (polímero insaturado de butadieno), polímeros de ácido acrílico, polímeros vinílicos (acetato de vinila, éter vinílico, cloreto de vinila), ou copolímeros destes;

- Soluções: Poliuretana e borracha silicônica;

- Sólidos (pós e pastas): Termoplásticos (copoliamidas, polietileno, EVA e PVC) e termofixos (resina fenólica).

As propriedades das fibras / filamentos representam um dos principais fatores na determinação das características dos não-tecidos. Algumas delas são: comprimento; tipo de seção transversal (circular, triangular, oca, trilobal); título $($ decitex ou denier $=$ massa em gramas por $10.000 \mathrm{~m}$ ou $9.000 \mathrm{~m}$ de comprimento $)$; matéria-prima; ponto de amolecimento e fusão; afinidade de tintura; frisagem; acabamento; e outras.

Os não-tecidos estão sendo crescentemente incorporados à prática assistencial em substituição aos tecidos não apenas para aventais, como também para embalagens de artigos médico-hospitalares, gorros, campos cirúrgicos e propés. Conforme se verifica acima, existem, no entanto, vários tipos de não-tecidos, de diferentes densidades e, portanto, de capacidade de barreira antimicrobiana e de 
retenção de líquidos. Assim, a garantia de capacidade de barreira antimicrobiana do avental cirúrgico não é dada apenas por ser constituído de material de não-tecido, sendo necessária sua aquisição a partir de especificações técnicas, que podem não ser as mesmas entre os diferentes fabricantes.

Os não-tecidos são geralmente de uso-único e sua incorporação na prática assistencial determinou a classificação das embalagens e componentes da paramentação cirúrgica como reutilizáveis ou reprocessáveis, geralmente de tecido, e uso-único ou descartável, geralmente de não-tecido.

Os três não-tecidos mais comumente utilizados para aventais cirúrgicos são: Spunlaced, constituído por fibras de poliéster e polpa de madeira, emaranhadas por um jato d' água sob pressão; SMS Spunbonded/Metblown/Spunbonded, formado pela união dessas três lâminas por um processo térmico ou adesivo, sendo que o spunbonded é um monômero ou polímero que é transformado para o estado de tecido, combinado com outras tecnologias para adquirir as propriedades necessárias para o uso hospitalar, o Meltblown é constituído de fibras unidas através de fluxo de ar de alta velocidade, derretendo as resinas, e proporcionando propriedades de barreira ou filtração ao SMS; Wet-laid, consiste em fibras de polpa de madeira ou mistura de poliéster com polpa de madeira que são agrupadas na formação de uma rede uniforme (RUTALA, WEBER, 2001; GOUVEIA, 1997).

Tanto os aventais de não-tecido como os de tecido podem ser reforçados com membranas impermeáveis, como o polietileno, para maior resistência contra penetração de líquidos e fluidos corpóreos. Geralmente este reforço é 
recomendado para cirurgias com perda de sangue acima de $100 \mathrm{ml}$ e duração que excede 2 horas ou cirurgias que envolvem a região abdominal (TELFORD, QUEBBEMAN, 1993).

\subsection{Revisão sistemática de literatura}

\subsubsection{Conceito}

A revisão sistemática de literatura constitui o método da Prática Baseada em Evidências, inicialmente designado como Medicina Baseada em Evidências. Esta metodologia, hoje, estende-se a várias ações assistenciais na área da saúde.

A Medicina Baseada em Evidências originou-se do movimento da epidemiologia anglo-saxônica, iniciado na Universidade McMaster no Canadá, no começo dos anos noventa do Século XX. É definida em termos genéricos como o "processo de sistematicamente descobrir, avaliar e usar achados de investigações como base para a tomada de decisões clínicas, a partir de dados provenientes da epidemiologia clínica e complementados com revisões sistemáticas da literatura" (CASTIEL, PÓVOA, 2002).

A revisão sistemática, permite ao pesquisador, distinguir uma intervenção eficiente daquela que não o é, resolver controvérsias em tratamentos e determinar ações terapêuticas que devem ser implementadas. Elas também identificam áreas nas quais são necessárias realizações de novas pesquisas, sendo 
uma referência cientificamente fundamentada para decisão sobre assistência à saúde (ATALLAH, CASTRO, 1998).

As principais orientações para a realização da revisão sistemática são fornecidas por centros ligados ao movimento da prática baseada em evidências, destacando-se a Colaboração Cochrane, na Inglaterra, que também reúne as revisões concluídas e constantemente atualizadas. Esse centro possui uma rede de vínculos em várias partes do mundo. Mas, conforme Castiel e Póvoa (2002), mesmo assumindo que as revisões do Cochrane são, em média, mais sistemáticas e menos enviesadas que estudos do mesmo teor publicados em outros periódicos, há investigações indicando que os resultados produzidos por esse centro também estão sujeitos a erros, incluindo problemas em métodos de análise. Esta foi uma conclusão de uma investigação realizada por participantes da secção nórdica do próprio centro, em relação a amostras de revisões de 1998. Muitas vezes, as conclusões dos trabalhos superestimavam benefícios de novas intervenções (OLSEN et al., 1998).

Embora se constitua uma importante ferramenta para nortear com mais segurança decisões assistenciais, esse novo método, porém apresenta seus limites metodológicos. E, mesmo que assim não fosse, autores preocupam-se com a possibilidade dela ser considerada como único recurso para qualificar ações assistenciais. Conforme Barata (2002), com o risco de reduzir “..a prática e o ensino na área da saúde a seus aspectos puramente técnicos, reforçando ainda mais a desumanização do cuidado, o descaso ante o vivido, o não compromisso face aos determinantes dos processos, a despolitização do empreendimento”. Castiel e Póvoa (2002) acrescentam, ainda, que "parâmetros, protocolos, metanálises, dados 
epidemiológicos são de extrema relevância na produção de conhecimento e, portanto, de teoria médica, mas não deverão substituir a arte do cuidar que demanda afinidades empáticas, habilidades intuitivas, para, eventualmente, em determinado caso, abrir mão da incorporação de 'evidências' ".

Há, contudo, determinadas ações cujas evidências independem da participação ativa do paciente e, mesmo, da experiência técnica do profissional. É o caso da necessidade ou não de incorporação de determinados insumos e tecnologias que resultem em acréscimo financeiro, mas não necessariamente em melhor qualidade assistencial, conforme ocorre freqüentemente na área de controle de infecção hospitalar.

\subsubsection{Método da revisão sistemática}

O método da revisão sistemática da literatura é utilizado para avaliar um conjunto de dados simultaneamente, a partir de estudos primários selecionados previamente, que investigam uma mesma questão. Ele permite reunir os dados desses estudos de forma organizada e analisá-los com recursos estatísticos, ou seja, realizar a metanálise (CASTRO et al., 2002).

A combinação de diferentes tipos de desenhos de pesquisas, incluindo tanto a literatura teórica como a empírica e a não exaustão da literatura que responde à questão da investigação caracteriza a revisão integrativa ou também denominada pela Colaboração Cochrane como revisão narrativa-discursiva. Diferese da revisão sistemática, que é a combinação de evidências de estudos básicos, por meio de métodos explícitos e reprodutíveis; considerando uma questão clínica 
específica. Além disto, há uma exaustão de busca de artigos científicos. Quando as evidências encontradas são semelhantes e permitem a análise pelo emprego de um método estatístico, esta pesquisa passa a ser denominada metanálise (WHITTERMORE, 2005).

O processo de combinação de evidências de múltiplos estudos primários é complexo, pois desvios (bias) ou erros podem ocorrer, no processo de inclusão e exclusão dos estudos. Dados de estudos podem ser incorretamente extraídos e interpretados e a análise pode ser realizada sem acurácia. Uma tabela de elementos-chave de cada estudo deve ser incluída com detalhes suficientes para avaliar sistematicamente cada estudo selecionado (WHITTERMORE, 2005; ATALLAH, 1997).

Atallah e Castro (1998) reúnem as vantagens da revisão sistemática:

a) Utiliza uma metodologia reprodutível.

b) Previne duplicação desnecessária de esforços, já que não precisa ser repetida por outro grupo de pesquisadores.

c) Pode ser rapidamente atualizada, com a inclusão de novos ensaios clínicos publicados.

d) Previne controvérsias na literatura, uma vez que não é o número de estudos favoráveis que conta, mas a soma de todos os casos adequadamente estudados. 
e) Antecipa em várias décadas o resultado de grandes ensaios clínicos, que ainda esperam para serem realizados devido a dificuldades técnicas e ou financeiras.

f) Detecta tratamentos inadequados em estágios mais iniciais de seu uso, portanto, salvando um grande número de pacientes de efeitos adversos de tratamentos desnecessários.

g) Aumenta a precisão dos resultados, o intervalo de confiança se estreita.

h) Define em que áreas mais ensaios clínicos são necessários.

i) Economiza recursos em assistência à saúde.

j) Auxilia decisões para políticas de saúde.

Esses autores também reconhecem, porém, algumas dificuldades:

a) Consome tempo, como em qualquer pesquisa científica de boa qualidade.

b) Envolve um trabalho intelectual desde a formulação da pergunta, desenvolvimento da estratégia para pesquisa, comparação dos trabalhos, interpretação dos dados.

c) Não consegue melhorar diretamente a qualidade dos estudos que compõem a revisão, pode apenas recomendar que os novos estudos não cometam os mesmos erros e promove 
sistematicamente a melhoria da qualidade dos ensaios clínicos a serem desenvolvidos.

d) É praticamente impossível fazer uma revisão sistemática sozinho, pois são necessários pelo menos dois profissionais para avaliar os ensaios clínicos.

e) É necessário aprender a trabalhar em equipe, desenvolver espírito colaborativo e "negociar" opiniões.

Segundo a Colaboração Cochrane, para elaboração da revisão sistemática devem ser seguidos sete passos (CASTRO et al., 2002).

$1^{\text {o }}$ passo: formulação da pergunta - condição para decidir sobre o que deve ou não ser incluído na revisão.

$2^{\circ}$ passo: localização e seleção dos estudos - não existe uma única fonte. Para identificar todos os estudos relevantes é preciso utilizar bases de dados eletrônicas (Medline, Embase, Lilacs, Cochrane Controlled Trials Database), verificar as referências bibliográficas dos estudos relevantes, solicitar estudos de colegas e pesquisar manualmente algumas revistas e anais de congressos.

$3^{\circ}$ passo: avaliação crítica dos estudos - utiliza-se critérios para determinar a validade dos estudos selecionados e a probabilidade de suas conclusões estarem baseadas em dados viciados. Com a avaliação crítica é possível determinar quais serão os estudos válidos para a revisão. Aqueles não preenchem 
os critérios de validade devem ser citados e explicados o porquê.

$4^{\circ}$ passo: coleta dos dados - todas as variáveis estudadas devem ser observadas nos estudos e resumidas, além das características do método, dos participantes e dos desfechos clínicos, que permitirão determinar a possibilidade de comparar ou não os estudos selecionados. Algumas vezes será necessário entrar em contato com o autor do estudo para pedir-lhe informações mais detalhadas.

$5^{\circ}$ passo: análise e apresentação dos dados - baseado na semelhança entre os estudos, eles serão agrupados para a metanálise. Cada um desses agrupamentos deverá ser préestabelecido no projeto, assim como a forma de apresentação gráfica e numérica, para facilitar o entendimento do leitor.

$6^{\circ}$ passo: interpretação dos resultados - é a determinação da força da evidência encontrada, a aplicabilidade dos resultados, informações sobre custo e a prática corrente que sejam relevantes, assim como determinar claramente os limites entre os benefícios e os riscos.

$7^{\circ}$ passo: aperfeiçoamento e atualização - uma vez publicada, a revisão sofrerá críticas e sugestões que devem ser incorporadas às edições subseqüentes, caracterizando uma publicação viva, e ainda ser atualizada cada vez que surja um novo estudo sobre o tema. 


\subsection{AVALIAÇÃO DE EVIDÊNCIA DE ESTUDOS}

Os adeptos da Medicina Baseada em Evidências consideram uma hierarquização da força ou validade das evidências de pesquisas a serem utilizadas nos processos decisórios nas práticas biomédicas. Esta hierarquia está baseada, fundamentalmente, no delineamento da pesquisa, indicando a sensibilidade do estudo. Ressalte-se, porém, que dizem respeito apenas a estudos quantitativos.

É apresentada, a seguir, uma classificação e definição das pesquisas quantitativas mais amplamente reconhecidas.

\subsubsection{Tipos de investigações}

Embora os tipos de pesquisas sejam similares em suas definições, algumas variações de classificação são encontradas, entre vários autores. A classificação apresentada, aqui, é a reunião daquelas obtidas no Dicionário de Epidemiologia, de Last (1988) e do livro de Epidemiologia Clínica, de Fletcher e Fletcher (2006).

\section{A - PESQUISA NÃO EXPERIMENTAL OU DE NÃO} INTERVENÇÃO

São consideradas as pesquisas bibliográficas, descritivas, analíticas ou observacionais, definidas conforme segue.

Pesquisa bibliográfica: procura explicar, conhecer ou analisar um problema a partir de referências teóricas publicadas em documentos. 
Pesquisa descritiva: observa, registra, analisa e correlaciona fatos ou fenômenos (variáveis) da realidade, sem interferência do pesquisador, ou seja, sem manipulá-los ou realizar intervenção. Aplicada principalmente nas ciências humanas e sociais. Para tanto, utiliza instrumentos como observação, entrevista, questionário e formulário. São reconhecidas seis formas de pesquisas descritivas:

a) Exploratória: pesquisa quase científica ou não científica, normalmente é o passo inicial no processo de pesquisa pela experiência e auxílio que traz na formulação de hipóteses significativas para posteriores pesquisas. Realiza descrições precisas da situação e quer descobrir as relações existentes entre seus elementos componentes;

b) Descritiva: estudo e descrição de características, propriedades ou relações existentes na comunidade, grupo ou realidade pesquisada. Favorecem, assim como os exploratórios, as tarefas de formulação clara do problema e da hipótese como tentativa de solução;

c) Opinião: procura saber atitudes, pontos de vista e preferências das pessoas sobre algum assunto;

d) Motivação: busca conhecer razões inconscientes e ocultas que levam, por exemplo, o consumidor a utilizar determinado produto ou que determinam certos comportamentos ou atitudes; 
e) Estudo de caso: pesquisa sobre um determinado indivíduo, família, grupo ou comunidade para examinar aspectos variados de sua vida;

f) Documental: investiga documentos a fim de se poder descrever e comparar usos e costumes, tendências, diferenças, etc.

Pesquisa analítica ou observacional: examina associações, comumente de relações causais sob hipótese. Usualmente busca identificar ou medir efeitos de fatores de risco ou de saúde específicos de exposição. Os indivíduos podem ser classificados de acordo com a ausência ou presença de uma doença específica e de acordo com "atributos" que podem influenciar a sua ocorrência (idade, raça, sexo, outras doenças, genética, bioquímica etc.). Os tipos mais comuns de pesquisas analíticas são:

a) Prevalência ou transversal (cross-sectional): examina a relação entre doenças (ou outras características relacionadas com a saúde) e outras variáveis de interesse em uma dada população em um dado período. A relação entre as variáveis e a doença pode ser examinada em termos de sua prevalência em diferentes sub-grupos da população, definidos de acordo com a presença ou ausência (ou nível) das variáveis na doença versus a não doença. A prevalência da doença, ao invés da incidência, é normalmente registrada em um estudo transversal. Este termo é empregado porque as pessoas são estudadas em corte 
transversal do tempo. Pode constituir um estudo experimental, quando ocorre intervenção.

b) Incidência, Coorte (cohort), concorrente, seguimento, longitudinal ou prospectivo: é o método epidemiológico em que um grupo de pessoas tem algo em comum. Ou, está, esteve ou estará exposta ou não exposta, ou exposta em diferentes graus, a um fator ou fatores sob hipótese que influencia a probabilidade de ocorrência de uma dada doença ou um dado resultado ou desfecho. É acompanhado por um período de tempo para se verificar o desenvolvimento do fator sob observação.

c) Caso-controle (case control), retrospectivo, comparativo, história de caso, caso referente: começa com a identificação de pessoas com a doença (ou outra variável) de interesse, e um grupo controle apropriado (comparação, referência) de pessoas sem a doença ou a variável. Tal estudo pode ser chamado de retrospectivo porque ele parte do resultado para suas causas. Os termos caso e controle são algumas vezes usados para descrever temas em um ensaio controlado randomizado, mas o termo estudo de caso-controle não deve ser usado para descrever tal estudo. Os termos caso-controle e retrospectivo têm sido usados mais freqüentemente para descrever este método, que também não deve ser confundido com estudos de coorte retrospectivos. 
d) Resultados terapêuticos (outcome research): avalia a efetividade dos tratamentos médicos. Os pesquisadores analisam resultados de intervenções terapêuticas que não foram realizadas por eles, o que os diferencia dos ensaios clínicos. Os dados são geralmente coletados dos prontuários e ou banco de dados administrativos. Geralmente mensuram mortalidade, morbidade, qualidade de vida, sobrevida livre de doença, estado funcional, efeitos adversos tardios e outros.

\section{B - PESQUISA EXPERIMENTAL OU DE INTERVENÇÃO}

Caracteriza-se por manipular diretamente as variáveis relacionadas com o objeto de estudo, proporcionando estudo da relação entre causas e efeitos de um determinado fenômeno. Através de situações de controle, procura evitar a interferência de variáveis intervenientes. Intervém na realidade, manipulando a variável independente a fim de observar o que acontece com a dependente. Para evitar vieses, os membros do grupo experimental e grupo controle devem ser comparáveis, exceto em relação à intervenção que está sob investigação. Para a epidemiologia clínica - ciência que faz predições sobre pacientes individuais utilizando a contagem de eventos clínicos em grupos de pacientes semelhantes e valendo-se de métodos científicos sólidos que conduzam a conclusões válidas, evitando o engano por erros sistemáticos ou aleatórios - é também denominada de ensaio clínico.

Ensaio clínico: compreendido como estudo em que o pesquisador realiza uma intervenção ativa e observa a ocorrência do desfecho. É um modelo de 
estudo prospectivo que compara o efeito e o valor de uma intervenção com controles em seres humanos. Podem ser classificados em:

a) Randomizados ou aleatorizados: os sujeitos numa população são alocados em grupos experimental e controle de forma aleatória, para receber ou não receber um procedimento, manipulação ou intervenção. Os resultados são acessados por comparação rigorosa da incidência de doença, morte, recuperação ou outro resultado apropriado nos grupos. Estes tipos de estudo são geralmente considerados como o método científico mais rigoroso de avaliação de testes de hipóteses, principalmente, efeitos de tratamento.

b) Não randomizados: quando os pacientes não são alocados aleatoriamente para os grupos controle e experimental.

c) Controlados: presença de um grupo de pacientes que serve como base de comparação na avaliação dos efeitos da intervenção de interesse que é dada aos pacientes do grupo experimental; estes pacientes podem não receber tratamento ou receber tratamento usual, padrão ou placebo.

d) Não controlados: presença exclusiva do grupo experimental. Descreve o curso de uma doença em único grupo de pacientes antes e depois da doença. Um outro nome para este tipo de delineamento é estudo antes-depois. 
Os ensaios clínicos também podem, por sua vez, serem classificados quanto a :

- Tipo de alocação: a) cegados, quando há desconhecimento do recebimento da intervenção. Se só o paciente desconhece, ele é uni-cego; se paciente e pesquisador desconhecem, ele é duplocego; se ambos e também o analista dos dados desconhecem, ele é triplo-cego; b) abertos: quando não houve tentativa de cegamento.

- Local da intervenção: a) Unicêntrico: quando é desenvolvido em apenas um centro de pesquisa; Multicêntrico, desenvolvido em mais de um centro de pesquisa.

- Controles históricos ou controles não-concorrentes: o investigador não tem controle do período ou local do estudo. A epidemiologia clínica define como controles históricos ou não concorrentes, pois os pacientes experimentais e controle podem ser reunidos em diferentes locais e momentos, como resultados de tratamento atual são algumas vezes comparados à experiência com pacientes semelhantes do passado. Esta abordagem é conveniente, porém o tempo e o lugar estão quase sempre estritamente relacionados ao prognóstico, aumentando fortemente a possibilidade de viés. 
Pesquisa transversal (Cross-sectional): conforme a epidemiologia

clínica, é um estudo em que o paciente recebe a intervenção experimental (ou intervenção controle) e, após um período estabelecido (wash-out), mudam de grupo e recebem a intervenção controle (ou a intervenção experimental). A ordem para administração do tratamento pode ser pré-estabelecida ou randomizada. Não existe grupo de pacientes para controle externo.

\section{PESQUISA SECUNDÁRIA}

São consideradas como pesquisa secundária:

Revisão narrativa: análise da produção direcionada a todos os aspectos de um dado assunto, ao invés de uma questão clínica exclusiva; tende a ser mais subjetiva. Pode incluir diversos modelos de estudo, bem como variados tipos de literatura, como carta ao editor e capítulos de livros. Não estabelece a qualidade das referências incluídas.

Revisão sistemática: já definida no item 2.2.

Metanálise: resultados da revisão sistemática que, quando homogêneos, podem ser combinados estatisticamente. A somatória dos resultados de estudos individuais recebe um peso com a metanálise, sendo os estudos analisados como sujeitos. 


\subsubsection{Métodos de avaliação da qualidade dos estudos}

Alguns modelos de escala hierárquica de níveis de evidência de qualidade de pesquisas vêm sendo propostos. O modelo citado por Castiel e Póvoa (2002), é o que segue:

I - Pelo menos uma revisão sistemática (metanálise) de múltiplos estudos randomizados (aleatorizados) controlados bem delineados.

II - Pelo menos um estudo randomizado (aleatorizado) controlado bem delineado, de tamanho adequado e com contexto clínico apropriado.

III - Estudo sem randomização (aleatorização), com grupo único, com análise pré e pós-coorte, séries temporais ou casocontrole pareados.

IV - Estudos bem delineados não experimentais, realizados em mais de um centro de pesquisa.

V - Opinião de autoridades respeitadas, baseadas em evidência clínica, estudos descritivos e relatórios de comitês de especialistas ou consensos.

A Escola de Medicina da Universidade de Yale (2005) discrimina um pouco mais a classificação acima, apresentando-a na forma de uma pirâmide, onde os níveis de evidência, em ordem decrescente, são os que seguem: 
I - Revisão sistemática

II - Sínteses de evidências (tópicos criticamente avaliados)

III - Sinopses de artigos (avaliados individualmente e criticamente)

IV - Ensaios clínicos randomizados

V - Estudos de coorte

VI - Estudos de caso-controle, casos seriados, relatórios

VII - Opinião de especialistas/ Seguimento de informações

As três categorias primeiras da classificação acima pressupõem informações "filtradas”, ou seja, já passaram por processo de avaliação dos estudos. As demais constituem informações "não filtradas", baseadas apenas nos delineamentos utilizados nas pesquisas.

Outro modelo de avaliação é o proposto pelo Centro de Medicina Baseada em Evidências de Oxford, cuja versão, adaptada por Nobre e Bernardo (2006) é apresentada no Quadro que segue. 
Quadro 2 - Graus de recomendações e níveis de evidência dos estudos terapêuticos em função do desenho de pesquisa.

\begin{tabular}{|c|l|l|}
\hline $\begin{array}{c}\text { Grau de } \\
\text { Recomendação }\end{array}$ & $\begin{array}{c}\text { Nível de } \\
\text { evidência }\end{array}$ & \multicolumn{1}{|c|}{ Estudos terapêuticos } \\
\hline \multirow{4}{*}{$\mathrm{A}$} & $1 \mathrm{a}$ & $\begin{array}{l}\text { Revisão sistemática (com homogeneidade) de ensaios clínicos } \\
\text { controlados e randomizados }\end{array}$ \\
\cline { 2 - 3 } & $1 \mathrm{~b}$ & $\begin{array}{l}\text { Ensaio clínico controlado e randomizado com intervalo de confiança } \\
\text { estreito }\end{array}$ \\
\cline { 2 - 3 } & $1 \mathrm{c}$ & Resultados terapêuticos do tipo "Tudo ou Nada" \\
\hline \multirow{3}{*}{$\mathrm{B}$} & $2 \mathrm{a}$ & Revisão Sistemática (com homogeneidade) de estudos de coorte \\
\cline { 2 - 4 } & $2 \mathrm{~b}$ & $\begin{array}{l}\text { Estudo de coorte (incluindo ensaio clínico randomizado de menor } \\
\text { qualidade) }\end{array}$ \\
\cline { 2 - 4 } & $2 \mathrm{c}$ & $\begin{array}{l}\text { Estudo observacional de resultados terapêuticos (outcome research) } \\
\text { e estudo ecológico }\end{array}$ \\
\cline { 2 - 4 } & $3 \mathrm{a}$ & $\begin{array}{l}\text { Revisão sistemática (com homogeneidade) de estudos de caso- } \\
\text { controle }\end{array}$ \\
\hline \multirow{2}{*}{$\mathrm{C}$} & 4 & $\begin{array}{l}\text { Relato de caso (incluindo coorte ou caso-controle de menor } \\
\text { qualidade) }\end{array}$ \\
\hline \multirow{2}{*}{$\mathrm{D}$} & 5 & $\begin{array}{l}\text { Opinião desprovida de avaliação crítica, baseada em consensos, } \\
\text { estudos fisiológicos, com materiais biológicos ou modelos animais }\end{array}$ \\
\hline
\end{tabular}

FONTE: Nobre e Bernardo (2006)

Constata-se, assim, que não há um único critério para análise de evidência de estudos. O que os modelos apresentados têm em comum é que, após os estudos secundários de avaliação crítica de pesquisas, os melhores seguintes são os de intervenção, ou ensaios clínicos. Estes, por sua vez, também são submetidos a critérios, que acrescem ou decrescem seu nível de evidência. Um deles é o instrumento criado e validado por Jadad et al. (1996), que avalia três condições, relacionadas com a redução de tendenciosidade (validade interna): 1) randomização; 2) cegamento; 3) perdas ou exclusões de participantes.

Os critérios de pontuações são os seguintes

a) $\mathrm{O}$ estudo recebe 1 ponto para cada uma das condições randomizado, cegado, perdas ou exclusões atendidas e 0 para as não atendidas. 
b) $\mathrm{O}$ estudo recebe mais 1 ponto adicional se:

- O método para gerar a sequiência de randomização foi descrito e apropriado e ou

- Se na condição 2 o método duplo-cego foi descrito e foi apropriado.

c) $\mathrm{O}$ estudo perde 1 ponto se:

- Na condição 1, o método para gerar a seqüência de randomização foi descrito e foi inapropriado e ou

- Na condição 2, o estudo foi descrito como duplo-cego, mas o método de cegamento foi inapropriado.

- As diretrizes para as avaliações acima são:

1) Randomização: o método de geração da seqüência aleatória é apropriado se permitir a cada participante do estudo ter a mesma chance de receber cada intervenção e o investigador não puder prever o próximo tratamento (tabela de sorteio de números, geração informatizada, etc). Métodos de randomização que usam datas de aniversário, admissão, número de registro no hospital ou alternância entre os grupos são considerados inadequados.

2) Duplo-cego: é assim considerado se a palavra "duplo-cego" foi usada. O método é considerado apropriado se foi realizado de 
maneira que nem o pesquisador, nem os participantes tiveram como identificar o tipo de intervenção utilizado ou, se na ausência de tal situação, os controles ativos, idênticos ou simulados foram mencionados.

3) Perdas e exclusões: participantes que foram incluídos no estudo, mas não completaram o período de observação ou não foram incluídos na análise precisam estar descritos. O número e as razões para as perdas ou exclusões em cada grupo precisam ser informados. Se não houve perdas, isto também deve ser informado no artigo. Se não houve informação de perdas, este item não deve ser pontuado.

A Escala de Jadad varia de 0 a 5 pontos e um estudo é considerado de qualidade pobre quando é classificado com menos de 3 pontos.

\subsection{Problemática para avaliação de estudos da área de controle de infecção hospitalar. Uma proposta.}

Poucos são os estudos de evidência já realizados na área de controle de infecção hospitalar. A experiência no ensino e pesquisa nessa área permite questionar a aplicação "pura" da revisão sistemática, analisando apenas o tipo de investigação, sem considerar as especificidades de seus objetos de estudo.

De uma forma geral, a avaliação de um estudo implica analisar suas validades interna e externa. Conforme Fletcher e Fletcher (2006), a validade interna é 
o grau em que os resultados de um estudo estão corretos para a amostra de pacientes sob análise. Ela é "interna" porque se aplica às condições clínicas do grupo específico de pacientes sob observação e não necessariamente a outros. A validade interna da pesquisa clínica é determinada pela forma como o delineamento, a coleta de dados e as análises são conduzidas, sendo ameaçada por todos os vieses e variações aleatórias. Para que uma observação clínica seja útil, a validade interna é uma condição necessária, mas insuficiente. Um estudo incontestável, com validade interna alta, pode ser totalmente enganoso se os resultados forem generalizados aos pacientes errados.

Contudo, no caso da área de controle de infecção hospitalar, quando se busca evidência de determinadas práticas de controle e prevenção, principalmente as que se referem às técnicas de assepsia, há a pretensão de que elas sejam válidas para qualquer grupo de pacientes sob procedimentos clínicos de intervenção no corpo biológico. Um exemplo, é a utilização de um mesmo produto antimicrobiano para anti-sepsia de pele em todos os pacientes. Outro é o uso de aventais cirúrgicos, objeto deste estudo, para qualquer tipo de cirurgia. Este poder de generalização de uma intervenção é denominado de validade externa.

A validade externa corresponde ao grau de veracidade dos resultados de uma observação em outros cenários. Ela mede, portanto, a capacidade de generalização. Assim, se os resultados de um estudo são verdadeiros, eles podem ser aplicados a outros pacientes também. Ela expressa a validade de se presumir que dadas intervenções em pacientes de um determinado estudo podem ser as mesmas para outros pacientes (FLETCHER, FLETCHER, 2006). 
Para Fletcher e Fletcher (2006), contudo, a capacidade de generalização das observações clínicas, mesmo daquelas com validade interna alta, é uma questão de julgamento pessoal, sobre a qual pessoas sensatas podem discordar. Ela raramente pode ser tratada de forma satisfatória em qualquer estudo. Isto porque, até mesmo uma população definida com base geográfica é uma amostra enviesada de populações maiores. Por exemplo, os pacientes hospitalizados são amostras enviesadas dos residentes de uma cidade.

A mesma situação pode ser considerada na amostragem de pacientes cirúrgicos. Como garantir que uma dada população sob intervenção, em um dado período, é passível de generalização? Uma alternativa é a utilização de amostras grandes. Tal situação, no entanto, determina, em consequiência, longo período de investigação ou estudos multicêntricos, porém resvalam em altas chances de variação de características intervenientes: rotatividade de pessoal, participação de diferentes categorias profissionais, variedade de técnicas cirúrgicas, uso de antibioticoprofilaxia, realização de degermação, preparo pré-operatório da pele, etc.

É freqüente encontrar, em estudos desta natureza, enorme variação de amostras e há que se concordar com Fletcher e Fletcher (2006), de que o melhor que o pesquisador pode fazer acerca da capacidade de generalização é garantir a validade interna.

Uma importante questão de difícil avaliação na validade interna de qualquer estudo é a garantia de similaridade de características dos grupos controle e experimental que podem interferir no desfecho. Fletcher e Fletcher (2006) reconhecem que a alocação aleatória não garante a semelhança entre os grupos. Para 
avaliar se ocorreu "má sorte" em estudos randomizados, muitas vezes há necessidade de comparar a freqüência destas características entre os grupos, isto é, constatar se as características que porventura tendem a interferir no resultado da intervenção estão igualmente presentes em ambos os grupos. Tal condição é denominada de estratificação dos grupos, antes da randomização ou realizar análise estatística de equivalência dos grupos após randomização.

Em muitas intervenções na área de controle de infecção hospitalar, contudo, tal condição ainda não constitui garantia de estudo de alta qualidade, se não for controlada a enorme gama de fatores intervenientes ou de risco para a ocorrência de infecção, além do objeto que se deseja investigar. Em outras palavras, as causas para o desenvolvimento de uma infecção são múltiplas e relacionadas tanto às características individuais dos pacientes (tipo de cirurgia, doenças secundárias, tabagismo, obesidade etc.), quanto aos procedimentos assistenciais e o ambiente (equipe cirúrgica, ambiente da sala de operações, uso ou não de antibioticoprofilaxia, preparo pré-operatório de pele, etc.).

É comum encontrar estudos nesta área temática que, embora não randomizados, apresentam melhor controle de tais fatores. Então, como garantir que eles não interferirão nos resultados? Uma alternativa é selecionar grupos os mais semelhantes possíveis (mesma cirurgia, mesmo local, mesma equipe etc.). Outra, é estratificar, pelo menos, os principais fatores de risco intervenientes antes da randomização.

Outra questão diz respeito ao tipo de desfecho. Nesta área de conhecimento os estudos analisam ora apenas o nível de contaminação microbiana na 
área e ou ferida operatória, ora a incidência de ocorrência de ISC ou, então, ambos ao mesmo tempo. O desenvolvimento de ISC é, obviamente, a questão central, mas ela depende de outros fatores além da contaminação, como os relacionados com tipo e quantidade de microrganismos e susceptibilidade individual. A contaminação, por sua vez, não determina, necessariamente, o desenvolvimento de ISC, mas constitui um “marcador" valioso, pois não é dependente de tantas variáveis individuais, como para o desenvolvimento de ISC. A presença, portanto, de ambos os desfechos em um mesmo estudo, permite conclusões mais contundentes e lhe acresce qualidade.

Tendo em vista as considerações acima e, no sentido de favorecer uma avaliação mais criteriosa dos estudos da presente revisão, optou-se pelo desenvolvimento de uma escala hierárquica de avaliação de qualidade específica para estudos sobre controle e prevenção de infecção cirúrgica. Esta escala baseou-se no modelo do Centro de Medicina Baseada em Evidências de Oxford, adaptada por Nobre e Bernardo (2006), acrescida de fatores intervenientes de riscos de infecção cirúrgica, extraídos das recomendações de melhores categorias das Diretrizes de Controle e Prevenção de Infecção do Sítio Cirúrgico do C.D.C. (MANGRAM et al., 1999), descritas anteriormente, no item 2.1.5. Além delas, considerou-se também o tipo de desfecho. Estes fatores são apresentados a seguir.

TC Tipo de cirurgia: mesmo tipo de cirurgia ou estratificação de diferentes tipos de cirurgias, com obtenção de não diferença significativa entre os grupos.

Justificativa: o mesmo tipo de cirurgia favorece o controle de um importante fator de risco, que é a duração do tempo operatório. 
PC: Potencial de contaminação de cirurgias: cirurgias limpas ou estratificação de cirurgias de diferentes potenciais de contaminação, com obtenção de não diferença significativa entre os grupos.

Justificativa: em cirurgias limpas não há manipulação de sítios com exceção da pele - que possuem microbiota própria, passível de constituir fonte de contaminação da ferida cirúrgica e que não depende do uso de barreiras exemplo: avental cirúrgico - e do controle do ambiente.

DC Duração da cirurgia: controle da duração das cirurgias, com obtenção de não diferença significativa entre os grupos.

Justificativa: a duração da cirurgia é considerada uma das variáveis do índice preditivo de risco cirúrgico, juntamente com o potencial de contaminação da cirurgia e o ASA. Assim sendo, até duas horas, o risco é zero, e acima de duas horas recebe 1 ponto.

EQ Equipe cirúrgica: mesma equipe cirúrgica ou mais de uma equipe, desde que descrita estratificação, sem diferença significativa entre os grupos.

Justificativa: a mesma equipe cirúrgica favorece a manutenção da mesma técnica e do tempo cirúrgico, fatores relevantes de riscos de ISC.

TP Técnica de preparo pré-operatório da pele do paciente: mesma técnica de preparo ou realização de técnicas diferentes, desde que descrita a estratificação, sem diferença significativa entre os grupos. O preparo deve incluir, pelo menos, os mesmos procedimentos de realização de tricotomia, quando necessária, e de anti-sepsia da pele ao redor da cirurgia. 
Justificativa: a microbiota da pele do paciente, sabidamente, é a principal fonte de contaminação da ferida e de ISC e o preparo pré-operatório da pele tem o objetivo de reduzir sua permanência e reprodução ao longo da cirurgia.

AT Antibioticoprofilaxia: mesmo esquema de antibioticoprofilaxia, que inclui droga, dose, momento de início e duração ou estratificação de diferentes esquemas entre os grupos, sem diferença significativa entre ambos.

Justificativa: o uso indevido e variado de antibióticos para prevenção ISC em cirurgias é a principal causa de desenvolvimento de microrganismos resistentes e constitui uma das principais recomendações de controle de riscos de ISC

SO $\underline{\text { Sala de operações: }}$ cirurgias realizadas na mesma sala ou em mais de uma sala, porém todas sob o mesmo sistema de ventilação $\underline{\text { e de }}$ paramentação cirúrgica. Caso contrário, é desejável que as salas com condições diferentes sejam estratificadas entre os grupos, sem diferença significativa entre eles.

Justificativa: a mesma sala de operações favorece graus semelhantes de contaminação do ar ambiente e de chances de sua queda diretamente no campo e na ferida cirúrgica.

FI Fatores de riscos intrínsecos: estratificação, entre os grupos, de pelo menos a classificação individual de risco ASA ou doenças secundárias associadas - que inclui, necessariamente, diabetes ex existência de focos infecciosos à distância, isto é, em sítios fora da área cirúrgica. 
Justificativa: condições de saúde individuais são fatores de risco relevantes para desenvolvimento de ISC. Os fatores acima são considerados recomendações de melhores categorias de prevenção.

DE Tipo de desfecho: análise de nível de contaminação e de desenvolvimento de ISC, com identificação de utilização dos mesmos critérios para seu diagnóstico.

Justificativa: ambos os desfechos permitem possibilidades distintas de análise.

O modelo de escala de avaliação de estudos proposto, que adiciona os critérios acima, é apresentado no Quadro 3. 
Quadro 3 - Escala de avaliação de qualidade de estudos da área de controle de infecção cirúrgica.

\begin{tabular}{|c|c|c|}
\hline $\begin{array}{c}\text { Grau de } \\
\text { Recomendação }\end{array}$ & $\begin{array}{l}\text { Nível de } \\
\text { evidência }\end{array}$ & Estudos \\
\hline \multirow{6}{*}{ A } & $\mathrm{A} 1+$ & $\begin{array}{l}\text { Revisão sistemática (com homogeneidade) de ensaios clínicos controla- } \\
\text { dos e randomizados, com análise de todos os fatores intervenientes de } \\
\text { risco propostos }\end{array}$ \\
\hline & A1- & $\begin{array}{l}\text { Revisão sistemática (com homogeneidade) de ensaios clínicos controla- } \\
\text { dos e randomizados, sem análise de todos os fatores intervenientes } \\
\text { propostos }\end{array}$ \\
\hline & $\mathrm{A} 2+$ & $\begin{array}{l}\text { Ensaio clínico controlado e randomizado com intervalo de confiança, } \\
\text { com análise de todos os fatores intervenientes de risco propostos }\end{array}$ \\
\hline & A2- & $\begin{array}{l}\text { Ensaio clínico controlado e randomizado com intervalo de confiança, } \\
\text { sem análise de todos os fatores intervenientes de risco proposto }\end{array}$ \\
\hline & A $2+$ & $\begin{array}{l}\text { Resultados terapêuticos do tipo "Tudo ou Nada" com análise de todos os } \\
\text { fatores intervenientes de risco propostos }\end{array}$ \\
\hline & A3- & $\begin{array}{l}\text { Resultados terapêuticos do tipo "Tudo ou Nada" sem análise de todos os } \\
\text { fatores intervenientes de risco propostos }\end{array}$ \\
\hline \multirow{8}{*}{ B } & $\mathrm{B} 1+$ & $\begin{array}{l}\text { Revisão Sistemática (com homogeneidade) de estudos de coorte, com } \\
\text { análise de fatores intervenientes de risco propostos }\end{array}$ \\
\hline & B1- & $\begin{array}{l}\text { Revisão Sistemática (com homogeneidade) de estudos de coorte, sem } \\
\text { análise de todos os fatores intervenientes de risco proposto }\end{array}$ \\
\hline & $\mathrm{B} 2+$ & $\begin{array}{l}\text { Estudo de coorte (incluindo ensaio clínico randomizado de menor } \\
\text { qualidade), com análise de todos os fatores intervenientes de risco } \\
\text { propostos }\end{array}$ \\
\hline & B2- & $\begin{array}{l}\text { Estudo de coorte (incluindo ensaio clínico randomizado de menor } \\
\text { qualidade), sem análise de todos os fatores intervenientes de risco } \\
\text { propostos }\end{array}$ \\
\hline & B3+ & $\begin{array}{l}\text { Estudo observacional de resultados terapêuticos (outcome research) e } \\
\text { estudo ecológico com análise de todos os fatores intervenientes de risco } \\
\text { propostos }\end{array}$ \\
\hline & B3- & $\begin{array}{l}\text { Estudo observacional de resultados terapêuticos (outcome research) e } \\
\text { estudo ecológico, sem análise de todos os fatores intervenientes de risco }\end{array}$ \\
\hline & B4+ & $\begin{array}{l}\text { Revisão sistemática (com homogeneidade) de estudos de caso-controle } \\
\text { com análise de todos os fatores intervenientes de risco }\end{array}$ \\
\hline & B4- & $\begin{array}{l}\text { Revisão sistemática (com homogeneidade) de estudos de caso-controle } \\
\text { sem análise de todos os fatores intervenientes de risco }\end{array}$ \\
\hline $\mathrm{C}$ & & $\begin{array}{l}\text { Relato de caso (incluindo coorte ou caso-controle de menor qualidade) } \\
\text { com análise de todos os fatores intervenientes de risco }\end{array}$ \\
\hline D & & $\begin{array}{l}\text { Opinião desprovida de avaliação crítica, baseada em consensos, estudos } \\
\text { fisiológicos, com materiais biológicos ou modelos animais }\end{array}$ \\
\hline
\end{tabular}

FONTE: Adaptado de Nobre e Bernardo (2006) 


\section{MATERIAL E MÉTODO}

\subsection{Tipo de estudo}

Tratou-se de estudo de revisão sistemática da literatura científica desenvolvido conforme as recomendações propostas pela Colaboração Cochrane, organização internacional sem fins lucrativos responsável por preparar, manter e assegurar o acesso às revisões sistemáticas na área da saúde (CASTRO et al., 2002).

\subsection{Questão do estudo}

A questão do estudo é o primeiro passo da revisão sistemática e funciona como a bússola de um navegador, ao buscar a direção apropriada, neste caso, a resposta que se deseja obter (CASTRO et al., 2002). A questão elaborada foi: Qual é a eficácia dos aventais cirúrgicos, conforme seu material de confecção, no controle da contaminação e ou infecção do sítio cirúrgico?

\subsection{Local do estudo}

Escola de Enfermagem da Universidade de São Paulo. 


\subsection{Critérios de inclusão dos estudos}

A partir da questão desta investigação foram considerados para a revisão sistemática apenas estudos básicos de intervenção, que investigaram a contaminação e ou a infecção do sítio cirúrgico com uso de aventais cirúrgicos reutilizáveis e ou descartáveis, utilizando como população pessoas submetidas a cirurgias, em situações reais ou simuladas. Foram, portanto, excluídos estudos primários laboratoriais (do tipo análise microbiana de barreiras), estudos secundários, publicações referentes a cartas ao leitor, duplicatas e réplicas, editais, comentários e opiniões, análise de literatura sem revisão sistemática com ou sem metanálise. Considerou-se, também, qualquer período, sem limitação de idioma.

\subsection{Amostragem}

\subsubsection{Fontes de busca dos estudos}

As buscas orientaram-se, inicialmente, pelas bases eletrônicas consideradas pelos centros internacionais de prática baseada em evidência, conforme seguem.

\section{CINAHAL, Cumulative Index to Nursing and Allied Health} Literature, indexa 2.737 periódicos na área de Enfermagem e assuntos correlatos a partir de 1982. Oferece acesso ao texto completo de mais de 400 publicações. É complementada pela base Pré-CINAHAL que contém citações recentes em 
processamento com publicações a partir de 1982. Acesso customizado dos seus serviços.

COCHRANE, a Biblioteca Cochrane é uma publicação eletrônica que disponibiliza evidências de alta qualidade. Inclui as seguintes bases de dados: revisões sistemáticas, Registros de Ensaios Clínicos Randomizados, Resumos de Revisões sobre efetividade, Avaliação tecnológica em Saúde e Avaliação Econômica da NHS. Acesso gratuito no Brasil e as atualizações são trimestrais.

EMBASE, serviço eletrônico da Elsevier que oferece acesso à base de dados EMBASE e MEDLINE. É a versão eletrônica das 52 seções da Excerpta Médica, contém mais de 15 milhões de registros bibliográficos com resumos da EMBASE desde 1974 e MEDLINE desde 1966 e links ao conteúdo de textos completos, caso a instituição tenha licença. Acesso customizado dos seus serviços.

LILACS, Literatura Latino-Americana e do Caribe em Ciências da Saúde, é uma base de dados cooperativa do sistema BIREME, Centro Especializado da Organização Pan-Americana de Saúde (OPAS) estabelecida no Brasil desde 1967. Contém artigos de aproximadamente 670 revistas mais conceituadas na área da saúde, atingindo mais de 150 mil registros, e outros documentos tais como: teses, capítulos de tese, livros, capítulos de livros, anais de congressos ou conferências, relatórios técnico-científicos e publicações governamentais. Acesso gratuito aos resumos dos artigos.

PubMed/MEDLINE, serviço da National Library of Medicine (NLM) dos Estados Unidos. Inclui acima de 16 milhões de citações de artigos da 
base Medline e outros jornais de artigos biomédicos desde 1950 até o momento. Acesso gratuito ao resumo dos artigos.

Outra fonte de busca foram as referências bibliográficas dos estudos selecionados na busca eletrônica, no sentido de identificar a presença de outros estudos não encontrados nesta busca.

Realizou-se também busca manual de todos os fascículos da Revista da Sociedade Brasileira de Enfermeiros de Centro Cirúrgico, Centro de Material e Recuperação Anestésica (SOBECC). Esta revista compila as principais publicações nacionais de estudos de enfermagem da área de centro cirúrgico, além das recomendações internacionais de procedimentos e práticas em salas de operações.

\subsubsection{Estratégia de busca nas bases de dados eletrônicas}

A revisão sistemática da literatura científica depende da localização de todos os estudos mais relevantes que respondem à pergunta da pesquisa, portanto há necessidade do uso de descritores, ou seja, de vocábulos ou terminologias que indexam os artigos por assunto eletronicamente ou não, possibilitando encontrar as publicações.

Nesta revisão, nem todas as palavras da pergunta, porém, correspondiam aos descritores eletrônicos controlados indexados. Isso porque é freqüente ainda encontrar indexação de artigos por descritores não controlados, principalmente daquelas publicações mais antigas, o que dificulta a busca. Uma vez 
que não houve limitação de período para a presente revisão, optou-se por ampliar os vocábulos de busca, acrescentando descritores não indexados.

A base de dados eletrônicos, como o MeSH (Medical Subject Headings Section) da PubMed/MEDLINE, conta com 22995 descritores, e o DeCS (Descritores em Ciências da Saúde) da BIREME com 26851 descritores. Os termos encontrados, mais próximos da pergunta desta pesquisa, foram: surgical wound infection (infecção da ferida cirúrgica), postoperative infection (infecção pósoperatória), protective clothing (vestuário de proteção), clothing (vestuário), textiles (têxtil), bedding and linens (roupas de cama, mesa e banho), operating room (sala de operação), cotton (algodão), disposable equipment (equipamento descartável).

Para os descritores não indexados foram utilizados termos utilizados nos próprios artigos científicos, conforme eram encontrados, que foram: single-use clothing (vestuário de uso-único) e reusable clothing (vestuário reutilizável), woven clothing (vestuário de tecido), non-woven clothing (vestuário de não tecido), staff clothing (vestuário da equipe), surgical wound contamination (contaminação da ferida cirúrgica), surgical site infection (infecção do sítio cirúrgico), surgical gowns (aventais cirúrgicos), operative gowns (aventais operatórios), disposable gowns (aventais descartáveis), garments (paramentação), operating room personnel (pessoal da sala de operação), drapes (campos cirúrgicos). A combinação desse último descritor deve-se ao fato de vários estudos analisarem concomitantemente aventais e campos cirúrgicos.

Uma condição básica para uma busca bem-sucedida é a utilização de "cruzamento" de palavras-chave, como a estratégia PICO, onde: $\mathrm{P}=$ Population 
(população ou situação clínica), I= Intervention (intervenção), C= Comparasion (comparação) e $\mathrm{O}=$ Outcome (Desfecho) (Nobre, Bernardo, Jatene, 2004). Aplicando tal estratégia a este estudo, considerou-se:

- $\mathrm{P}=$ pacientes cirúrgicos - surgical patients

- I = roupa hospitalar ou roupa de proteção - clothing / protective clothing

- $\mathrm{C}=$ uso-único ou reutilizável - single-use or reusable

- $\mathrm{O}=$ contaminação ou infecção da ferida operatória - surgical wound contamination or surgical wound infection

Nesta revisão foram incluídos os estudos com os componentes do PICO, conforme descrição abaixo:

- População: estudos sobre pacientes submetidos a cirurgias no ambiente do centro Cirúrgico, independente da idade, sexo, etnia, tipo de cirurgia realizada.

- Intervenção: o uso de aventais cirúrgicos de tecido ou não tecido pela equipe cirúrgica durante cirurgias limpas, potencialmente contaminadas e contaminadas. É um componente fundamental da pergunta desta pesquisa, portanto estes descritores participaram da técnica da estratégia de localização dos artigos nas bases de dados eletrônicas. 
- Comparação: o estudo pode ou não apresentar comparação do avental de tecido com o não tecido. Como não será obrigatoriedade para seleção dos estudos a comparação destes dois tipos de materiais de confecção do avental, este componente não foi incluso na técnica de combinação dos descritores.

- Desfecho: presença de contaminação da ferida operatória ou de desenvolvimento de infecção do sítio cirúrgico. Como componente indispensável da pergunta da pesquisa, o desfecho também foi combinado com a intervenção para buscar os artigos científicos que respondam à questão deste estudo.

O Quadro abaixo exemplifica a estratégia de localização dos artigos por meio da utilização dos operadores booleanos AND e ou OR.

Quadro 4 - $\quad$ Estratégia de busca usada para localizar os estudos nas bases eletrônicas. São Paulo, 2007.

\begin{tabular}{|c|c|c|c|c|}
\hline Estratégica de Busca & Descritor básico indexado & & Sinônimo & \\
\hline I - Intervenção & Clothing (Vestuário) & OR & $\begin{array}{l}\text { Protective Clothing } \\
\text { (Vestuário de Proteção) }\end{array}$ & AND \\
\hline O-Desfecho & $\begin{array}{l}\text { Surgical Wound Infection } \\
\text { (Infecção da Ferida Cirúrgica) }\end{array}$ & OR & $\begin{array}{l}\text { Surgical Site Infection } \\
\text { (Infecção do Sítio Cirúrgico) }\end{array}$ & AND \\
\hline
\end{tabular}

Houve necessidade, nesta revisão, de combinar intervenção (I) com desfecho (O), utilizando os conectores booleanos AND entre os descritores. Além desta técnica foi necessário o uso de sinônimos que estavam ou não indexados nas bases de dados, como surgical wound infection, descritor indexado, que possui o sinônimo surgical site infection, para evitar não localizar estudos relevantes para esta 
pesquisa. Podemos verificar no Apêndice 1, o quadro referente às divisões dos descritores por intervenção, comparação e desfecho.

Com o objetivo de garantir a maior segurança possível, de que todas as publicações relevantes seriam encontradas, utilizaram-se, ainda, a combinação da estratégia 1 com a 2, usando o booleano AND e os descritores em inglês nas bases de dados PubMed/MEDLINE, CINAHL, EMBASE e COCHRANE e descritores em inglês, português e espanhol na base de dados LILACS :

\section{- Estratégia de busca 1}

surgical wound infection OR surgical site infection OR surgical wound contamination OR postoperative infection

\section{- Estratégia de busca 2}

clothing OR garments OR surgical gowns OR protective clothing OR bedding and linens OR textiles OR cotton OR staff clothing OR reusable clothing OR single-use clothing OR woven or non woven clothing OR operating room OR disposable equipment OR operating room personnel OR operative gowns OR disposable gowns OR drapes OR gowns OR drape OR linen.

\section{- Combinação das estratégias 1 e 2 na base de dados CINAHL}

surgical and wound and infection or surgical and site and infection or surgical and wound and contamination or postoperative and infection and clothing or garments or surgical and gowns or protective and clothing or bedding and linens or textiles or cotton or staff and clothing or reusable and clothing or single-use and clothing or woven or non and clothing or operating and room or disposable and equipment or operating and room and personnel or operative and gowns or disposable and gowns or drapes or gowns or drape or linen.

\section{- Combinação das estratégias 1 e 2 na base de dados EMBASE}

((Surgical AND wound AND infection OR surgical AND site AND infection OR surgical wound AND contamination OR postoperative AND infection AND clothing OR garments OR surgical AND gowns OR protective) AND (clothing OR bedding AND linens OR textiles OR cotton OR staff AND clothing OR reusable AND clothing OR single-use AND clothing OR woven OR non AND woven AND clothing OR operating AND room OR disposable AND equipment OR operating AND room AND personnel OR operative AND gowns OR disposable AND gowns OR drapes OR gowns OR drapE OR linen)).

\section{- Combinação das estratégias 1 e 2 na base de dados LILACS}

infeccao da FERIDA operatoria" or "infeccao de FERIDA pos-operatoria" or (tw Surgical and tw Wound and tw Infection) or (tw Infección and tw Herida and tw Operatoria) or (tw sitio and tw cirurgico and tw infeccao) or (tw contaminação and tw ferida and tw cirurgica) [Descritor de assunto] and ( "ROUPA de protecao" or "ROUPAs de cama, mesa e banho" or (tw protective and tw clothing) or (tw Ropa and tw Protección) or (tw bedding or tw linens) or (tw Surgical or tw Sponges) 
or (twTapones and tw Quirúrgicos and tw Gaza) or (tw Tampões and tw Gaze and tw Cirúrgicos) or Salas de Cirurgia or (tw Operating and tw Rooms) or tw Quirófanos or ) or (tw "AVENTAL" or tw "CIRURGICO") or (tw operating and tw room and tw clothing) or (tw roupa and tw sala and tw cirurgica) or (tw disposable and tw equipment) or (tw apron and tw cirurgico) or ( $t w$ "PARAMENTACAO" or tw "PARAMENTOS") .

\section{- Combinação das estratégias 1 e 2 na base de dados COCHRANE}

((surgical and wound and infection or surgical and site and infection or surgical and wound and contamination or postoperative and infection) and (clothing or garments or surgical and gowns or protective and clothing or bedding and linens or textiles or cotton or staff and clothing or reusable and clothing or single-use and clothing or woven or non and clothing or operating and room or disposable and equipment or operating and room and personnel or operative and gowns or disposable and gowns or drapes or gowns or drape or linen))

\section{Combinação das estratégias 1 e 2 na base de dados PubMed/MEDLINE}

("surgical wound infection"[MeSH Terms] OR surgical wound infection[Text Word]) OR (("operative surgical procedures"[Text Word] OR "surgical procedures, operative"[MeSH Terms] OR surgical[Text Word]) AND site[All Fields] AND ("infection"[MeSH Terms] OR ("communicable diseases"[TIAB] NOT Medline[SB]) OR "communicable diseases"[MeSH Terms] OR infection[Text Word])) OR (("operative surgical procedures"[Text Word] OR "surgical procedures, operative"[MeSH Terms] OR surgical[Text Word]) AND (("wounds and injuries"[TIAB] NOT Medline[SB]) OR "wounds and injuries"[MeSH Terms] OR wound[Text Word]) AND contamination[All Fields]) OR ((("postoperative period"[TIAB] NOT Medline[SB]) OR "postoperative period"[MeSH Terms] OR postoperative[Text Word]) AND ("infection"[MeSH Terms] OR ("communicable diseases"[TIAB] NOT Medline[SB]) OR "communicable diseases"[MeSH Terms] OR infection[Text Word]))

("clothing"[MeSH Terms] OR clothing[Text Word]) OR (("clothing"[TIAB] NOT Medline[SB]) OR "clothing"[MeSH Terms] OR garments[Text Word]) OR (("operative surgical procedures"[Text Word] OR "surgical procedures, operative"[MeSH Terms] OR surgical[Text Word]) AND gowns[All Fields]) OR ("protective clothing"[MeSH Terms] OR protective clothing[Text Word]) OR ("bedding and linens"[MeSH Terms] OR bedding and linens[Text Word]) OR ("textiles"[MeSH Terms] OR textiles[Text Word]) OR (("gossypium"[TIAB] NOT Medline[SB]) OR "gossypium"[MeSH Terms] OR cotton[Text Word]) OR (staff[All Fields] AND ("clothing"[MeSH Terms] OR clothing[Text Word])) OR (reusable[All Fields] AND ("clothing"[MeSH Terms] OR clothing[Text Word])) OR (singleuse[All Fields] AND ("clothing"[MeSH Terms] OR clothing[Text Word])) OR woven[All Fields] OR (non[All Fields] AND woven[All Fields] AND ("clothing"[MeSH Terms] OR clothing[Text Word])) OR (("operating rooms"[TIAB] NOT Medline[SB]) OR "operating rooms"[MeSH Terms] OR operating room[Text Word]) OR ("disposable equipment"[MeSH Terms] OR disposable equipment[Text Word]) OR ((("operating rooms"[TIAB] NOT Medline[SB]) OR "operating rooms"[MeSH Terms] OR operating room[Text Word]) AND ("manpower"[Subheading] OR personnel[Text Word])) OR (operative[All 
Fields] AND gowns[All Fields]) OR (disposable[All Fields] AND gowns[All Fields]) OR drapes[All Fields] OR gowns[All Fields] OR (drap[All Fields] OR drap/bace2[All Fields] OR drap/dt[All Fields] OR drap1[All Fields] OR drap1/nc2alpha[All Fields] OR drap27[All Fields] OR drap27/cd9[All Fields] OR drap622[All Fields] OR drapac[All Fields] OR drapaca[All Fields] OR drapael[All Fields] OR drapaka[All Fields] OR drapal[All Fields] OR drapala[All Fields] OR drapalik[All Fields] OR drapalo[All Fields] OR drapalova[All Fields] OR drapalski[All Fields] OR drapamapandey[All Fields] OR drapanas[All Fields] OR drapanas'[All Fields] OR drapanas's[All Fields] OR drapanocytaire[All Fields] OR drapaport[All Fields] OR draparnapandey[All Fields] OR draparnaud[All Fields] OR draparnaudi[All Fields] OR drapau[All Fields] OR drapaul[All Fields] OR drapc1[All Fields] OR drapchinskaia[All Fields] OR drapcho[All Fields] OR drape[All Fields] OR drape'[All Fields] OR drapeanestesi[All Fields] OR drapeau[All Fields] OR drapeaup[All Fields] OR draped[All Fields] OR draped'[All Fields] OR drapeforming[All Fields] OR drapeholder[All Fields] OR drapek[All Fields] OR drapel[All Fields] OR drapela[All Fields] OR drapella[All Fields] OR drapelova[All Fields] OR drapelovau[All Fields] OR draper[All Fields] OR draper's[All Fields] OR draperclan[All Fields] OR draperd[All Fields] OR draperh[All Fields] OR draperi[All Fields] OR draperies[All Fields] OR drapernaud[All Fields] OR drapers[All Fields] OR draperworld[All Fields] OR drapery[All Fields] OR drapes[All Fields] OR drapes'[All Fields] OR drapetis[All Fields] OR drapetomania[All Fields] OR drapeza[All Fields] OR drapezo[All Fields] OR draphael[All Fields] OR drapier[All Fields] OR drapiewski[All Fields] OR drapiezii[All Fields] OR drapiezne[All Fields] OR drapieznikow[All Fields] OR drapieznych[All Fields] OR drapin[All Fields] OR draping[All Fields] OR drapings[All Fields] OR drapinski[All Fields] OR drapisch[All Fields] OR drapka[All Fields] OR drapkin[All Fields] OR drapkina[All Fields] OR drapkove[All Fields] OR drapnirala[All Fields] OR drapo[All Fields] OR drapp[All Fields] OR drappa[All Fields] OR drappanova[All Fields] OR drappaport[All Fields] OR drappasani[All Fields] OR drappatz[All Fields] OR drappi[All Fields] OR drappier[All Fields] OR drapping[All Fields] OR drappo[All Fields] OR drappole[All Fields] OR drapport[All Fields] OR drappus[All Fields] OR drapron[All Fields] OR draps[All Fields] OR drapsin[All Fields] OR drapslag[All Fields] OR drapsmenn[All Fields] OR drapsproteiner[All Fields] OR drapstiltale[All Fields] OR drapsules[All Fields] OR draptchinskaia[All Fields] OR draptchinskaya[All Fields] OR draptor[All Fields] OR drapurbaks[All Fields] OR drapwehner[All Fields]) OR (linen[All Fields] OR linen/laundry[All Fields] OR linen's[All Fields] OR linenal[All Fields] OR linenalis[All Fields] OR linenberg[All Fields] OR linenberger[All Fields] OR linendoll[All Fields] OR linenfelser[All Fields] OR linenge[All Fields] OR linenger[All Fields] OR linenger's[All Fields] OR linenhall[All Fields] OR linenko[All Fields] OR linenkugel[All Fields] OR linennym[All Fields] OR linens[All Fields] OR linens'[All Fields] OR linenscin[All Fields] OR linenthal[All Fields] OR linenweber[All Fields]) 


\subsubsection{Seleção dos estudos}

Os estudos foram buscados pela autora desta investigação. Todos aqueles obtidos a partir dos descritores utilizados foram avaliados pelos títulos e resumos. Nos casos em que os títulos e resumos não eram suficientes para definir sua primeira seleção, buscou-se a íntegra da publicação.

Após a identificação de todos os estudos a partir dos descritores, procedeu-se à análise para sua pré-seleção, de acordo com a questão norteadora e os critérios de inclusão previamente definidos. Essa etapa foi realizada separadamente por dois revisores - a autora dessa investigação e sua orientadora, que extraíram independentemente os dados, conforme formulário previamente elaborado (Apêndice 2).

Posteriormente, ocorreu uma reunião de consenso, com o objetivo de decidir a inclusão e a exclusão das pesquisas pré-selecionadas. Tal procedimento visou a controlar vieses (bias) ou erros, garantindo maior segurança na seleção. Os estudos incluídos foram analisados conforme formulário previamente elaborado (Apêndice 3) e receberam um código com o objetivo de facilitar a leitura e sua identificação: E1, E2, E3 etc.

\subsection{Análise dos dados}

Os dados foram extraídos por meio do instrumento previamente elaborado (Apêndice 3), sendo dispostos em Quadros e Tabelas, seguidos de descrições. As Tabelas foram apresentadas com números absolutos e percentuais. 
Os dados analisados foram apresentados em três fases:

Fase 1: Caracterização do processo de seleção dos estudos, contendo:

- Total de estudos identificados na busca, de acordo com a fonte.

- Identificação de estudos repetidos.

- Exclusão de estudos.

- Estudos incluídos para revisão sistemática

Fase 2: Caracterização dos estudos incluídos, quanto a:

- Informações de publicação

- Escopos

- Objetos sob investigação (somente aventais ou aventais juntamente com outros componentes de paramentação cirúrgica e controle de ambiente)

- Caracterização dos aventais cirúrgicos investigados conforme confecção

- Tipos de delineamento da investigação

- Processos de alocação dos estudos randomizados

- Desfechos analisados 
- Critérios diagnósticos de ISC e de contaminação da ferida operatória

- Variáveis de risco extrínsecas e intrínsecas controladas

- Estratificação de variáveis controladas

- Relação amostra de população/controle de variáveis

Fase 3: Avaliação de qualidade e evidência dos estudos incluídos, contendo:

- Escala de avaliação de qualidade de estudos da área de controle de infecção cirúrgica, proposta no capítulo anterior, item 2.2.4 deste estudo.

- Escala de Jadad, explicitada no capítulo anterior, item 2.2.3

- Evidência dos estudos incluídos, conforme ambas escalas

- Síntese panorâmica do conteúdo e da análise dos estudos incluídos 


\section{RESULTADOS}

Os resultados são apresentados em três fases: caracterização do processo de seleção dos estudos encontrados na busca; caracterização dos estudos incluídos para revisão sistemática; avaliação de qualidade e de evidência dos estudos incluídos na revisão sistemática.

\subsection{Caracterização do processo de seleção dos estudos encontrados na busca}

Todas as publicações identificadas foram obtidas a partir das bases eletrônicas. A busca pelas referências bibliográficas das publicações selecionadas não foi necessária, pois todas as de interesse à questão da investigação já haviam sido identificadas pelas bases eletrônicas. Nenhum estudo foi encontrado por pesquisa manual.

No Quadro abaixo, verifica-se o total de estudos encontrados na busca realizada, a partir dos descritores, conforme a base de dados.

Quadro 5 - Número de estudos encontrados, pré-selecionados, descartados e incluídos, segundo as bases de dados eletrônicas. São Paulo, 2007.

\begin{tabular}{|c|c|c|c|c|c|}
\hline 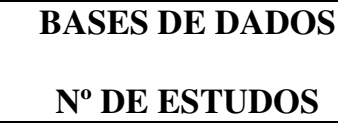 & PubMed/MEDLINE & CINAHL & EMBASE & COCHRANE & LILACS \\
\hline Encontrados & 1697 & 173 & 59 & 248 & \\
\hline Pré-selecionados & 20 & 03 & 07 & 07 & $=$ \\
\hline Descartados & 08 & 02 & 01 & 01 & 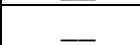 \\
\hline Incluídos & 12 & 01 & 06 & 06 & - \\
\hline
\end{tabular}


A base eletrônica que proporcionou a maior quantidade de publicações foi a PubMed/MEDLINE (1697), seguida pela COCHRANE (248), CINAHL (173), EMBASE (59) e LILACS (0). Na base de dados da COCHRANE, os estudos são classificados em revisões sistemáticas, resumos de revisões sistemáticas com qualidade avaliada, ensaios controlados, revisões de metodologia, registros sobre metodologia e sobre a Colaboração COCHRANE, resumos de avaliação de tecnologias de saúde e econômicas. Não houve nenhuma revisão sistemática sobre o tema da investigação dentre as 82 revisões encontradas com o uso dos descritores combinados, discriminados anteriormente. Quanto aos ensaios clínicos, foram encontrados 101 estudos. Na base de dados EMBASE, optou-se pelo acesso apenas nesta base, excluindo a base MEDLINE.

A maioria das publicações pré-selecionados estavam na base de dados PubMed/MEDLINE, EMBASE e COCHRANE. Muitos estudos se repetiram entre as bases de dados eletrônicas e também houve estudos duplicados na mesma base de dados. Vale ressaltar que não foi identificado nenhum artigo na base LILACS com o uso de descritores em português e espanhol.

A estratégia de busca, combinando os descritores indexados ou não, sem restrição do tipo de investigação, data, idioma e outras características que podem limitar a localização nas fontes de busca, ofereceram enorme garantia de que praticamente todos os estudos relevantes foram obtidos.

Do total de publicações encontradas apenas 20 delas, após avaliação dos seus títulos e resumos, correspondiam a estudos básicos e se relacionavam com a questão específica da investigação. Assim, foram excluídos 
todos os estudos secundários: as revisões narrativo-discursivas, cartas ao leitor, editoriais e entrevistas. A leitura e análise subseqüente da íntegra dos estudos primários pré-selecionados, realizada isoladamente por duas revisoras (autora e orientadora), definiram pela exclusão de oito (8) deles. Os motivos das exclusões foram os seguintes:

- Mesmas investigações, porém publicadas duas vezes, com títulos e em periódicos diferentes, sendo incluída apenas uma delas.

- Investigação de uniforme privativo convencional versus descartável, que não incluía o avental cirúrgico.

- Investigação somente de campos cirúrgicos.

- Avaliação de paramentação completa de ar ultra limpo.

Tais estudos excluídos são descritos detalhadamente no Apêndice 4. A amostra definitiva dos artigos incluídos para revisão sistemática, portanto, constituiu-se de 12 artigos, apresentados a seguir.

\subsection{Caracterização dos estudos incluídos para revisão sistemática}

O Quadro 6, abaixo, relaciona os estudos incluídos, quanto a informações de sua publicação. 
Quadro 6 - Estudos incluídos para revisão sistemática, segundo dados de publicação. São Paulo, 2007.

\begin{tabular}{|c|c|c|c|c|c|}
\hline Est. & Autor (es) & Título & Fonte & Origem & Ano \\
\hline E1 & $\begin{array}{l}\text { Garibaldi, R.A; } \\
\text { Maglio, S; Lerer, T; } \\
\text { Becker, D; Lyons, R }\end{array}$ & $\begin{array}{l}\text { Comparison of Nonwoven and } \\
\text { Woven Gown and Drape Fabric to } \\
\text { prevent intraoperative wound } \\
\text { contamination and postoperative } \\
\text { infection }\end{array}$ & Am J Surg & EUA & 1985 \\
\hline E2 & $\begin{array}{l}\text { Bellchambers, J; } \\
\text { Harris, J.M; Cullinan, } \\
\text { P; G } \\
\text { aya, H; Pepper, J.R. } \\
\end{array}$ & $\begin{array}{l}\text { A prospective study of wound } \\
\text { infection in coronary artery surgery }\end{array}$ & $\begin{array}{l}\text { Eur J Cardio- } \\
\text { Thoracic Surg. }\end{array}$ & Inglaterra & 1998 \\
\hline E3 & $\begin{array}{l}\text { Moylan, J. A; } \\
\text { Kennedy, B. V. }\end{array}$ & $\begin{array}{l}\text { The importance of gown and drape } \\
\text { barriers in the prevention of wound } \\
\text { infection }\end{array}$ & $\begin{array}{l}\text { Surg, Gynecol } \\
\& \text { Obst }\end{array}$ & EUA & 1980 \\
\hline $\mathrm{E} 4$ & $\begin{array}{l}\text { Bergman, b. R; } \\
\text { Hoborn, J; } \\
\text { Nachemson, A.L. }\end{array}$ & $\begin{array}{l}\text { Patient draping and staff clothing in } \\
\text { the operating theatre: a } \\
\text { microbiological study }\end{array}$ & $\begin{array}{l}\text { Scand J Infect } \\
\text { Dis }\end{array}$ & Suécia & 1985 \\
\hline E5 & $\begin{array}{l}\text { Tavitian, J. D; Taub, } \\
\text { N.A; Taylor, G. J.S }\end{array}$ & $\begin{array}{l}\text { Body-exhaust suit versus occlusive } \\
\text { clothing: a randomised, prospective } \\
\text { trial using air and wound bacterial } \\
\text { counts }\end{array}$ & $\begin{array}{l}\text { J Boné and } \\
\text { Joint Surg }\end{array}$ & Inglaterra & 2003 \\
\hline E6 & $\begin{array}{l}\text { Moylan, J.A; } \\
\text { Fitzpatrick, K.T; } \\
\text { Davenport, K.E. }\end{array}$ & $\begin{array}{l}\text { Reducing wound infections: } \\
\text { improved gown and drape barrier } \\
\text { performance }\end{array}$ & Arch Surg & EUA & 1987 \\
\hline E7 & $\begin{array}{l}\text { Ha ' eri, G.B \& } \\
\text { Wiley, A.M }\end{array}$ & $\begin{array}{l}\text { Wound contamination through } \\
\text { drapes and gowns. A study using } \\
\text { tracer particles }\end{array}$ & $\begin{array}{l}\text { Clin Orthop } \\
\text { and Related } \\
\text { Res }\end{array}$ & Canadá & 1980 \\
\hline E8 & $\begin{array}{l}\text { Verkala, K; Eklund, } \\
\text { A; Ojajävi, J; } \\
\text { Tiittanen, L; Hoborn, } \\
\text { J; Mäkelä, P }\end{array}$ & $\begin{array}{l}\text { The conventionally ventilated } \\
\text { operating theatre anda ir } \\
\text { contamination control during } \\
\text { cardiac surgery bacteriological and } \\
\text { particulate matter control garment } \\
\text { options for low level contamination }\end{array}$ & $\begin{array}{l}\text { Eur J Cardio- } \\
\text { Rhoracic Surg. }\end{array}$ & Suécia & 1998 \\
\hline E9 & $\begin{array}{l}\text { Billings, L, Vasseur, } \\
\text { P. B; Fancher, C; } \\
\text { Miller, M; } \\
\text { Nearenberg, D }\end{array}$ & $\begin{array}{l}\text { Wound infection rates in dogs and } \\
\text { cats after use of cotton muslin or } \\
\text { disposable impermeable fabric as } \\
\text { barrier material } 720 \text { case (1983- } \\
\text { 1989) }\end{array}$ & JAVMA & EUA & 1990 \\
\hline E10 & $\begin{array}{l}\text { Treggiari, M; } \\
\text { Benevento, A; } \\
\text { Caronno, R; Dionigi, } \\
\text { R. }\end{array}$ & $\begin{array}{l}\text { Valutazione dell'efficacia di teli e } \\
\text { camici in tessuto non tessuto verso } \\
\text { teli e camici in cotone nel ridurre } \\
\text { l'incidenza delle infezioni } \\
\text { postoperatorie della ferita }\end{array}$ & Minerva Chir & Itália & 1992 \\
\hline E11 & $\begin{array}{l}\text { Muller W, Jiru P, } \\
\text { Mach R, Polaschek F, } \\
\text { Fasching W. }\end{array}$ & $\begin{array}{l}\text { Der Einsatz von Einwegabdeckung } \\
\text { im Operationssaal und sein Einflub } \\
\text { auf dier postoperative } \\
\text { wundinfektionrate. }\end{array}$ & $\begin{array}{l}\text { Wierner } \\
\text { Klinishe } \\
\text { Wochenschrift }\end{array}$ & Áustria & 1989 \\
\hline E12 & $\begin{array}{l}\text { Benediktsdóttir, E \& } \\
\text { Kolstad }\end{array}$ & $\begin{array}{l}\text { Non-sporeforming anaerobic } \\
\text { bacteria in clean surgical wounds - } \\
\text { air and skin contamination. }\end{array}$ & $\begin{array}{l}\text { J of Hospital } \\
\text { Infection }\end{array}$ & Suécia & 1984 \\
\hline
\end{tabular}


Observa-se, no Quadro acima, que as fontes de publicações são diversificadas e a maioria dos estudos tem origem americana (04), seguindo-se sueca (03), inglesa (02), canadense (01), italiana (01) e austríaca (01). Quanto à data de publicação, sete situam-se na década de 1980 e cinco entre 1990 - 2003. Não foi encontrado nenhum estudo de origem brasileira.

A Tabela 1, a seguir, apresenta as variáveis dependentes sob intervenção dos estudos submetidas à investigação.

Tabela 1 - Distribuição dos estudos incluídos para revisão sistemática conforme as variáveis submetidas a investigações. São Paulo, 2007.

\begin{tabular}{lccc}
\hline Componentes da Paramentação Cirúrgica & Código dos Estudos & \multicolumn{2}{c}{ Total } \\
& & $\mathbf{N}^{\circ}$ & $\mathbf{\%}$ \\
\hline Aventais cirúrgicos & E 5 & 1 & 8,3 \\
Aventais e campos cirúrgicos & E1,E2,E3,E6,E7,E9,E10,E11 & 8 & 66,7 \\
Aventais, campos e uniforme privativo & E 8 & 1 & 8,3 \\
Aventais e uniforme privativo & E 12 & 1 & 8,3 \\
Aventais, campos, uniforme, gorro, máscara & E 4 & 1 & 8,3 \\
e ventilação da SO & & $\mathbf{1 2}$ & $\mathbf{1 0 0 , 0}$ \\
\hline Total & & \\
\hline
\end{tabular}

Na Tabela 1, nota-se que o avental cirúrgico, objeto desta revisão sistemática, foi analisado isoladamente em apenas um estudo (E5). Os demais investigaram os aventais cirúrgicos juntamente com outros componentes da paramentação, principalmente com campos cirúrgicos $(66,7 \%)$, seguido de uniforme privativo, aventais e campos cirúrgicos $(8,3 \%)$; aventais e uniforme privativo $(8,3 \%)$; aventais, campos, uniforme privativo, gorro, máscara e ventilação da $\mathrm{SO}(8,3 \%)$.

Conforme o material de confecção, os aventais cirúrgicos foram classificados em reprocessáveis e de uso-único, ilustrados no Quadro 7 abaixo. 
Quadro 7 - Distribuição dos estudos incluídos para revisão sistemática conforme os tipos de confecção dos aventais cirúrgicos reutilizáveis e de uso-único utilizados. São Paulo, 2007.

\begin{tabular}{|l|l|l|}
\hline ESTUDOS & \multicolumn{1}{|c|}{ Reutilizáveis } & \multicolumn{1}{c|}{ Uso-único } \\
\hline E1 & algodão + poliéster (180) + reforços (270) & mistura de poliéster \\
\hline E2 & não discriminado & não discriminado \\
\hline E3 & Algodão (280) e (140) & spunbonded* olefin \\
\hline E4 & Algodão + reforços & viscose + poliamida interna \\
\hline E5 & BES** (roupa de exaustão) & Rotecno spunlaced $* * *$ \\
\hline E6 & Algodão (280) & Spunlaced $*$ \\
\hline E7 & não discriminado & não-tecido Barrier® \\
\hline E8 & Algodão + reforços & Polipropileno \\
\hline E9 & Algodão (140) & Polipropileno spunlaced $*^{*}$ \\
\hline E10 & Algodão & TNT FABRIC 450**** \\
\hline E 11 & não discriminado & não discriminado \\
\hline E12 & Algodão & não-tecido Barrier 450® \\
\hline
\end{tabular}

*Spunbonded, Spunlaced: vide descrições no capítulo sobre abordagem teórica, item 2.1.4

** BES: paramentação de exaustão, utilizada em ar ultralimpo.

*** ROTECNO - filamentos extremamente finos e contínuos de poliéster

****TNT FABRIC 450 - formado por fibras de polímero e celulose

Constata-se, no Quadro 7, que o material de confecção dos aventais de uso-único, ou de não-tecido, foram discriminados na maioria dos estudos. Em cinco deles, porém, não foi possível identificar o tipo de material, pois ou ele foi referido apenas pelo nome comercial (E7, E10, E12) ou genericamente como descartável (E2, E11). Quanto aos aventais reutilizáveis, a maioria foi designada, simplesmente, como de "algodão", composição mista algodão/poliéster, com reforço e exaustão (BES). Apenas quatro estudos preocuparam-se em descrever a composição da trama (E1, E3, E6, E9). E, observe-se, não houve coincidência entre eles. No desenho dos estudos também não houve referências sobre suas condições de uso, ou seja, se eram novos, reusados e tempo de uso.

Os tipos de investigações dos estudos são apresentados na Tabela

2. 
Tabela 2 - Distribuição dos estudos incluídos para revisão sistemática, conforme os tipos de investigações. São Paulo, 2007.

\begin{tabular}{lccc}
\hline \multicolumn{1}{c}{ Tipo de investigação } & $\begin{array}{c}\text { Código dos } \\
\text { Estudos }\end{array}$ & \multicolumn{2}{c}{ Total } \\
& $\mathbf{N}^{\circ}$ & \% \\
\hline Ensaio clínico controlado randomizado & E1,E2,E5,E8 & 4 & 33,3 \\
Ensaio clínico controlado não randomizado (sem & E10 & 1 & 8,3 \\
aleatorização) & E04, E12 & 2 & 16,7 \\
Ensaio clínico não controlado (sem grupo controle) & E3,E6,E7,E11 & 4 & 33,3 \\
Controles históricos ou não concorrentes & E9 & 1 & 8,3 \\
Observacional de resultado terapêutico & & 12 & 100 \\
\hline Total & & 12 \\
\hline
\end{tabular}

Dos 12 estudos sob análise, quatro deles utilizaram o melhor método considerado em estudos de revisão sistemática, que é o ensaio clínico controlado randomizado (E1, E2, E5, E8). A mesma quantidade de estudos utilizou o método de controle histórico ou não concorrente (E3, E6, E7, E11), que são estudos experimentais cujos grupos controle e experimental não ocorrem ao mesmo tempo ou no mesmo local. Os outros estudos foram: ensaio clínico controlado não randomizado (E10), ou seja, os pacientes não são aleatorizados para os grupos; ensaio clínico não controlado (E4, E12), sem o grupo controle, e um estudo retrospectivo classificado como observacional de resultado terapêutico (E9). 
Tabela 3 - Distribuição dos estudos incluídos para revisão sistemática, conforme os desfechos investigados. São Paulo, 2007.

\begin{tabular}{lccc}
\hline \multicolumn{1}{c}{ Desfecho } & \multirow{2}{*}{ Estudos } & \multicolumn{2}{c}{ Total (N=12) } \\
& & $\mathbf{N}^{\circ}$ & \% \\
\hline ISC & E2, E3, E6, E9, E11 & 5 & 41,7 \\
Contaminação da FO e/ou área operatória & E4, E5, E7, E8, E12 & 5 & 41,7 \\
Contaminação da FO e/ou área operatória + ISC & E1, E10 & 2 & 16,7 \\
\hline Total & & $\mathbf{1 2}$ & $\mathbf{1 0 0 , 0}$ \\
\hline
\end{tabular}

Quanto ao desfecho, a maioria dos estudos ora avaliou somente a ocorrência de ISC (E2, E3, E6, E9, E11) e ora apenas a contaminação da ferida cirúrgica (E4, E5, E7, E8, E12). Apenas dois deles (E1 e E10) verificaram as duas situações.

Os recursos utilizados para a obtenção dos desfechos foram variados e são apresentados no Quadro 8.

Quadro 8 - $\quad$ Recursos utilizados para analisar os desfechos das investigações dos estudos incluídos para revisão sistemática, conforme seus desfechos. São Paulo, 2007.

\begin{tabular}{|c|c|c|c|c|c|}
\hline \multirow{2}{*}{ Critérios } & \multirow{2}{*}{$\begin{array}{c}\text { Contaminação } \\
(N=5)\end{array}$} & \multirow{2}{*}{$\operatorname{ISC}(\mathbf{N}=5)$} & \multirow{2}{*}{$\begin{array}{c}\text { Contaminação } \\
\text { e ISC }(\mathrm{N}=2)\end{array}$} & \multicolumn{2}{|c|}{ Total $(\mathrm{N}=12)$} \\
\hline & & & & $\mathbf{N}^{\circ}$ & $\%$ \\
\hline Presença de pus & & E3,E9,E11 & E1 & 04 & 33,3 \\
\hline Cultura da FO & $\mathrm{E} 4, \mathrm{E} 5, \mathrm{E} 7, \mathrm{E} 8, \mathrm{E} 12$ & $\overline{-}$ & $\mathrm{E} 1, \mathrm{E} 10$ & 07 & 58,3 \\
\hline Leucograma & - & - & E10 & 01 & 8,3 \\
\hline Deiscência de FO & $\overline{-}$ & E9 & - & 01 & 8,3 \\
\hline Reoperação & $\overline{-}$ & E11 & $\overline{-}$ & 01 & 8,3 \\
\hline Sinais: eritema, edema, dor & $=$ & E9 & $=$ & 01 & 8,3 \\
\hline Score Assepsis* & $\overline{-}$ & E2 & $\overline{-}$ & 01 & 8,3 \\
\hline $\begin{array}{l}\text { ConselhoNacional } \\
\text { Pesquisa } \\
\end{array}$ & - & E3,E6 & - & 02 & 16,7 \\
\hline Uso de antibiótico & - & - & E10 & 01 & 8,3 \\
\hline
\end{tabular}

*Score Assepsis: escala numérica para classificar as ISC em incisionais superficiais, profundas e de ossos.

O recurso de análise de cultura da ferida operatória foi usado por todos os estudos com desfecho de contaminação da FO (58,3\%). Para diagnosticar a ISC vários critérios foram utilizados, prevalecendo presença de pus $(33,3 \%)$, seguido 
pelas determinações de diagnóstico de ISC do Conselho Nacional de Pesquisa, as quais não foram especificadas. Os dois estudos que avaliaram ambos os desfechos, realizaram cultura da FO.

O controle de variáveis externas, ou de fatores intervenientes, é fundamental em investigações dessa natureza. Elas constituem os demais fatores predisponentes à contaminação da ferida e de ocorrência de ISC, além do uso de aventais cirúrgicos. Para maior clareza, tais fatores foram classificados em extrínsecos (relacionados aos procedimentos e ambiente hospitalar) e intrínsecos (relacionados principalmente ao paciente).

Esclareça-se, contudo, que nos estudos que investigaram apenas a contaminação da ferida os fatores intrínsecos perdem a sua força de representação de risco, uma vez que as condições específicas dos pacientes, apesar de contribuírem fundamentalmente para o desenvolvimento de infecção, não necessariamente favorecem maior ou menor contaminação da ferida. Com a finalidade de melhor separar tais situações, nas Tabelas 4 e 5, que contêm os fatores extrínsecos e intrínsecos, os estudos são sub-classificados conforme seus desfechos. 
Tabela 4 - Distribuição da freqüência de fatores de risco extrínsecos controlados nos estudos incluídos para revisão sistemática, conforme os desfechos. São Paulo, 2007.

\begin{tabular}{|c|c|c|c|c|c|c|}
\hline \multirow{2}{*}{$\begin{array}{c}\text { Tipo de desfecho } \\
\text { Variáveis extrínsecas }\end{array}$} & \multicolumn{2}{|c|}{$\begin{array}{c}\text { Contaminação } \\
(\mathrm{N}=5)\end{array}$} & \multicolumn{2}{|c|}{ ISC $(\mathbf{N}=5)$} & \multicolumn{2}{|c|}{$\begin{array}{l}\text { Contaminação e } \\
\text { ISC }(\mathrm{N}=\mathbf{2})\end{array}$} \\
\hline & $\mathbf{N}^{\circ}$ & $\%$ & $\mathbf{N}^{\circ}$ & $\%$ & $\mathbf{N}^{\circ}$ & $\%$ \\
\hline Preparo pré-operatório & 2 & 40,0 & 1 & 20,0 & 1 & 50,0 \\
\hline Tempo pré-operatório & - & $\ldots$ & 1 & 20,0 & 1 & 50,0 \\
\hline Antibioticoprofilaxia & 3 & 60,0 & 5 & 100,0 & 1 & 50,0 \\
\hline Equipe cirúrgica & 4 & 80,0 & 3 & 60,0 & - & _ \\
\hline Duração da cirurgia & 1 & 20,0 & 4 & 80,0 & 2 & 100,0 \\
\hline Tipo de cirurgia & 5 & 100,0 & 5 & 100,0 & 2 & 100,0 \\
\hline Técnica cirúrgica & 2 & 40,0 & - & — & - & — \\
\hline Ventilação da SO & 5 & 100,0 & 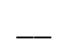 & 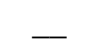 & - & - \\
\hline $\mathrm{N}^{\circ}$ pessoas na $\mathrm{SO}$ & 1 & 20,0 & 2 & $\overline{40,0}$ & $\overline{1}$ & $\overline{50,0}$ \\
\hline Movimentação na SO & 3 & 60,0 & - & - & - & _ \\
\hline Mesma SO & 2 & 40,0 & 2 & $\overline{40,0}$ & - & - \\
\hline Irrigação da ferida & 1 & 20,0 & 1 & 20,0 & - & - \\
\hline Horas de ventilação & - & - & 1 & 20,0 & - & - \\
\hline Furos nas luvas & 1 & 20,0 & - & - & - & - \\
\hline
\end{tabular}

$\mathrm{Na}$ Tabela 4, constata-se que os fatores extrínsecos mais controlados pelos estudos foram tipo de cirurgia (12), antibioticoprofilaxia (9), duração da cirurgia e equipe cirúrgica (7). Dentre os estudos com desfecho de contaminação, predominaram os fatores tipo de cirurgia, ventilação da SO, equipe cirúrgica, movimentação na SO e antibioticoprofilaxia. Os fatores antibioticoprofilaxia, tipo de cirurgia, duração da cirurgia e equipe cirúrgica, também com maior frequiência de controle, devem-se ao fato de que tais estudos acompanharam o desfecho de ISC.

Apesar de todos os estudos terem identificado os tipos de cirurgias realizadas durante as intervenções, esclareça-se que a maioria considerou vários tipos de cirurgias, ainda que sob a mesma especialidade. Por exemplo, os E3, E9, E10, E11 utilizaram cirurgias de diferentes potenciais de contaminação, inclusive contaminadas e sujas. 
Tabela 5 - Distribuição da frequiência de fatores de risco intrínsecos controlados nos estudos incluídos para revisão sistemática, conforme os desfechos. São Paulo, 2007.

\begin{tabular}{|c|c|c|c|c|c|c|}
\hline \multirow[t]{2}{*}{$\begin{array}{c}\text { Tipo de desfecho } \\
\text { Variáveis extrínsecas }\end{array}$} & \multicolumn{2}{|c|}{$\begin{array}{l}\text { Contaminação } \\
\qquad(N=5)\end{array}$} & \multicolumn{2}{|c|}{ ISC $(\mathbf{N}=5)$} & \multicolumn{2}{|c|}{$\begin{array}{c}\mathrm{ISC}+ \\
\text { Contaminação } \\
\text { ISC }(\mathrm{N}=2)\end{array}$} \\
\hline & $\mathbf{N}^{\circ}$ & $\%$ & $\mathbf{N}^{\circ}$ & $\%$ & $\mathbf{N}^{\circ}$ & $\%$ \\
\hline Doenças pré-existentes & - & - & 1 & 20,0 & 1 & 50,0 \\
\hline Idade & $\overline{1}$ & $\overline{20,0}$ & 4 & 80,0 & 1 & 50,0 \\
\hline Sexo & 1 & 20,0 & 3 & 60,0 & 2 & 100,0 \\
\hline Fumo & - & - & 1 & 20,0 & - & - \\
\hline Estado nutricional & - & - & - & - & 1 & 50,0 \\
\hline IMC $*$ & - & - & $\overline{1}$ & $\overline{20,0}$ & — & - \\
\hline $\mathrm{ASA}^{* *}$ & - & - & - & - & $\overline{1}$ & $\overline{50,0}$ \\
\hline
\end{tabular}

*IMC: índice de massa corpórea

** ASA: avaliação do paciente para risco de ISC

Pela Tabela 5, observa-se que os fatores intrínsecos mais controlados foram sexo (6), idade (6) e doenças pré-existentes (2). Os estudos que mais analisaram tais fatores foram os que acompanharam desfechos de ISC e essas características constituem antes fatores de risco para ISC do que para contaminação.

Os Quadros 9 e 10, a seguir, têm a finalidade de favorecer a visualização do total de fatores intrínsecos e extrínsecos controlados, em cada estudo. 
Quadro 9 - Distribuição dos estudos incluídos para revisão sistemática, conforme as variáveis extrínsecas controladas. São Paulo, 2007.

\begin{tabular}{|c|c|c|c|c|c|c|c|c|c|c|c|c|c|c|c|}
\hline $\mathbf{E}$ & Desfecho & $\begin{array}{c}\text { Preparo } \\
\text { Pré }\end{array}$ & $\begin{array}{l}\text { Tempo } \\
\text { de pré- } \\
\text { op }\end{array}$ & ATB & Equipe & $\begin{array}{l}\text { Duração } \\
\text { cirurgia }\end{array}$ & $\begin{array}{l}\text { Tipo de } \\
\text { Cirurgia }\end{array}$ & $\begin{array}{l}\text { Técnica } \\
\text { Cirúrgica }\end{array}$ & $\begin{array}{l}\text { Ventila- } \\
\text { ção SO }\end{array}$ & $\begin{array}{c}\text { Pessoas } \\
\text { na SO }\end{array}$ & $\begin{array}{c}\text { Movimen- } \\
\text { tacão na } \\
\text { SO } \\
\end{array}$ & $\begin{array}{c}\text { Única } \\
\text { SO }\end{array}$ & $\begin{array}{l}\text { Irrigação } \\
\text { da Ferida }\end{array}$ & \begin{tabular}{|c|} 
Furos \\
nas \\
luvas \\
\end{tabular} & $\begin{array}{c}\text { Horas } \\
\text { De } \\
\text { ventilação }\end{array}$ \\
\hline E1 & $\begin{array}{l}\text { Contaminação } \\
\text { e ISC }\end{array}$ & $X$ & $\mathrm{X}$ & $\mathrm{X}$ & & $\mathrm{X}$ & $X$ & & & $X$ & & & & $X$ & \\
\hline E2 & ISC & & $X$ & $\mathrm{X}$ & $X$ & $\mathrm{X}$ & $X$ & & & $\mathrm{X}$ & & & & & $\mathrm{X}$ \\
\hline E3 & ISC & & & $\mathrm{X}$ & $\mathrm{X}$ & $X$ & $\mathrm{X}$ & & & & & & $X$ & & \\
\hline E4 & Contaminação & & & & $\mathrm{X}$ & & $\mathrm{X}$ & & $\mathrm{X}$ & & $\mathrm{X}$ & & & & \\
\hline E5 & Contaminação & & & $\mathrm{X}$ & $\mathrm{X}$ & & $X$ & $X$ & $\mathrm{X}$ & $\mathrm{X}$ & & $X$ & & & \\
\hline E6 & ISC & & & $\mathrm{X}$ & $\mathrm{X}$ & $X$ & $\mathrm{X}$ & & & & & $X$ & & & \\
\hline E7 & Contaminação & & & & & & $X$ & & $\mathrm{X}$ & & $X$ & & & & \\
\hline E8 & Contaminação & $X$ & & $\mathrm{X}$ & $\mathrm{X}$ & & $\mathrm{X}$ & $\mathrm{X}$ & $\mathrm{X}$ & $\mathrm{X}$ & $X$ & $X$ & & & \\
\hline E9 & ISC & $\mathrm{X}$ & & $\mathrm{X}$ & & & $X$ & & & & & & & & \\
\hline E10 & $\begin{array}{l}\text { Contaminação } \\
\text { e ISC }\end{array}$ & & & & & $\mathrm{X}$ & $\mathrm{X}$ & & & & & & & & \\
\hline E11 & ISC & & & $\mathrm{X}$ & & $\mathrm{X}$ & $\mathrm{X}$ & & & & & $\mathrm{X}$ & & & \\
\hline E12 & Contaminação & $\mathrm{X}$ & & $\mathrm{X}$ & $\mathrm{X}$ & $\mathrm{X}$ & $\mathrm{X}$ & & $\mathrm{X}$ & & & & & & \\
\hline
\end{tabular}


Quadro 10 - Distribuição dos estudos incluídos para revisão sistemática, conforme variáveis intrínsecas controladas. São Paulo, 2007

\begin{tabular}{|l|l|c|c|c|c|c|c|c|}
\hline E & \multicolumn{1}{|c|}{ Desfecho } & $\begin{array}{c}\text { Doenças pré- } \\
\text { existentes }\end{array}$ & Idade & Sexo & Fumo & Estado nutricional & IMC & ASA \\
\hline E1 & Contaminação e ISC & $\mathrm{X}$ & $\mathrm{X}$ & $\mathrm{X}$ & & $\mathrm{X}$ & $\mathrm{X}$ \\
\hline E2 & ISC & $\mathrm{X}$ & $\mathrm{X}$ & $\mathrm{X}$ & $\mathrm{X}$ & & & \\
\hline E3 & ISC & & $\mathrm{X}$ & $\mathrm{X}$ & & & \\
\hline E4 & Contaminação & & & & & & \\
\hline E5 & Contaminação & & & & & & \\
\hline E6 & ISC & & $\mathrm{X}$ & $\mathrm{X}$ & & & \\
\hline E7 & Contaminação & & & & & & \\
\hline E8 & Contaminação & & & & & & \\
\hline E9 & ISC & & & $\mathrm{X}$ & & & \\
\hline E10 & Contaminação e ISC & & $\mathrm{X}$ & $\mathrm{X}$ & & & \\
\hline E11 & ISC & & & & & \\
\hline E12 & Contaminação & & & & & \\
\hline
\end{tabular}


No Quadro 9, o estudo E8 foi o que controlou o maior número de fatores extrínsecos (9), seguido pelo E1 (7), E2 (7), E5 (7), E12 (6) E3 (5) e o E6 (5). Os demais (E4, E7, E9, E10 e E11) controlaram 4, 3 ou 2 fatores.

No Quadro 10, a maioria dos estudos controlou um número ínfimo de fatores intrínsecos ou não houve esse controle. Observam-se dois estudos de desfecho de ISC que controlaram maior número destes fatores E1 (5) e E2 (5).

Conforme já foi discutido no item 2.3.1, a randomização nem sempre é garantia de que as variáveis que podem interferir no desfecho são distribuídas de maneira eqüitativa entre os grupos experimental e controle. A Tabela 6, a seguir, mostra os estudos, conforme sua explicitação ou não desta questão.

Tabela 6 - Distribuição dos estudos incluídos para revisão sistemática, conforme análise de diferenças estatísticas das variáveis extrínsecas e intrínsecas entre os grupos controle e experimental. São Paulo, 2007.

\begin{tabular}{cccc}
\hline Análise estatística & Estudos & $\mathbf{N}^{\circ}$ & Total \\
& & 2 & $\%$ \\
\hline Sim & E1, E2 & 8 & 66,7 \\
Não & E3,E5, E6,E7,E8, E9,E10,E11 & 2 & 16,7 \\
\hline Sem grupo controle & E4, 12 & 12 & 100,0 \\
\hline Total & &
\end{tabular}


Nenhum estudo realizou estratificação de variáveis de risco de contaminação e ou ISC, de modo a garantir a equivalência entre os controle e experimental. Conforme a Tabela 6, a maioria dos estudos $(66,7 \%)$ também não realizou análise estatística de distribuição destas variáveis entre os grupos após a intervenção. Ressalve-se o tipo de cirurgia ou potencial de contaminação de cirurgia (E3, E6, E9 e E11).

Somente os estudos E1 e E2 realizaram análise estatística de características entre os grupos após a intervenção. Nesses casos, não foi obtida diferença estatisticamente significativa entre os grupos, com exceção da Diabetes mellitus, no E2, com maior freqüência no grupo de descartáveis.

O Quadro seguinte correlaciona as variáveis de risco controladas com as amostras das populações investigadas. 
Quadro 11 - Estudos incluídos para revisão sistemática conforme populações e quantidade de variáveis de risco controladas. São Paulo, 2007.

\begin{tabular}{|c|c|c|c|c|c|c|}
\hline \multirow{2}{*}{ Estudo } & \multirow{2}{*}{ População } & \multirow{2}{*}{ Estudo } & \multicolumn{2}{|c|}{ Grupos } & $\begin{array}{c}\text { Variáveis } \\
\text { extrínsecas } \\
\text { controladas }\end{array}$ & $\begin{array}{c}\text { Variáveis } \\
\text { Intrínsecas } \\
\text { controladas }\end{array}$ \\
\cline { 4 - 5 } & & & Experimental & Controle & 07 & 05 \\
\hline E1 & 494 & E1 & 226 & 268 & 07 & 05 \\
\hline E2 & 500 & E2 & 250 & 250 & 05 & 02 \\
\hline E3 & 2253 & E3 & 1100 & 1153 & 04 & - \\
\hline E4 & 27 & E4 & Sem grupo controle & 07 & - \\
\hline E5 & 50 & E5 & 25 & 25 & 05 & - \\
\hline E6 & 2181 & E6 & 1060 & 1121 & 03 & - \\
\hline E7 & 80 & E7 & 40 & 40 & 09 & 01 \\
\hline E8 & 66 & E8 & 32 & 34 & 03 & 01 \\
\hline E9 & 720 & E9 & 360 & 360 & 02 & 02 \\
\hline E10 & 50 & E10 & 25 & 25 & 04 & - \\
\hline E 11 & 1033 & E 11 & 679 & 354 & 06 & - \\
\hline E12 & 64 & E12 & \multicolumn{7}{|l}{ Sem grupo controle } & & - \\
\hline
\end{tabular}

Verifica-se que a quantidade de variáveis controladas não esteve diretamente relacionada com o tamanho das populações. Os estudos com menores populações não foram os que mais controlaram variáveis e viceversa. Os estudos E4 e E10, com menores populações, também foram os que menos controlaram variáveis. Apenas um estudo (E1) citou equivalência estatística de suficiência de amostra.

\subsection{Avaliação de qualidade e evidência dos estudos incluídos para revisão sistemática}

Optou-se por dois métodos para esta avaliação. Um deles é a

Escala de Avaliação de Qualidade de Estudos da Área de Controle de Infecção 
Cirúrgica (EQCIC), proposta no capítulo 2, item 2.4, a qual incorpora, além do tipo de investigação, as variáveis de risco para contaminação da ferida operatória e ISC. O outro é a Escala de Jadad, explicitada no capítulo 2, item, 2.3.2, a qual incorpora e refina a categorização de estudos amplamente utilizada pelos Centros de Práticas Baseadas em Evidências.

A primeira escala aceita vários tipos de delineamento de estudos. Já, a segunda dirige-se apenas aos ensaios clínicos. 
Quadro 12 - Evidência dos estudos incluídos conforme Escala de Avaliação de Qualidade de Estudos da Área de Controle de Infecção Cirúrgica (EQCIC). São Paulo, 2007.

\begin{tabular}{|c|c|c|}
\hline $\begin{array}{c}\text { Grau de } \\
\text { recomendação }\end{array}$ & Nível de evidência & Estudos \\
\hline \multirow{4}{*}{ A } & $\mathrm{A} 1+$ & \\
\hline & $\mathrm{A} 1-$ & \\
\hline & $\mathrm{A} 2+$ & \\
\hline & $\mathrm{A} 2-$ & $\mathrm{E} 1, \mathrm{E} 2, \mathrm{E} 5, \mathrm{E} 8$ \\
\hline & $\mathrm{A} 3+$ & \\
\hline & $\mathrm{A} 3-$ & \\
\hline \multirow{4}{*}{} & $\mathrm{B} 1+$ & \\
\hline & $\mathrm{B} 1-$ & \\
\hline & $\mathrm{B} 2+$ & \\
\hline & $\mathrm{B} 2-$ & $\mathrm{E} 3, \mathrm{E} 4, \mathrm{E} 6, \mathrm{E} 7, \mathrm{E} 10, \mathrm{E} 11, \mathrm{E} 12$ \\
\hline & $\mathrm{B} 3+$ & \\
\hline \multirow{4}{*}{$\mathrm{B}$} & $\mathrm{B} 3-$ & $\mathrm{E} 9$ \\
\hline & $\mathrm{B} 4+$ & \\
\hline & $\mathrm{B} 4-$ & \\
\hline & & \\
\hline $\mathrm{C}$ & & \\
\hline $\mathrm{D}$ & & \\
\hline
\end{tabular}

A1 $^{+}$Revisão sistemática (com homogeneidade) de ensaios clínicos controlados e randomizados, com análise de todos os fatores intervenientes de risco propostos; A1 $^{-}$Revisão sistemática (com homogeneidade) de ensaios clínicos controlados e randomizados, sem análise de todos os fatores intervenientes propostos; $\mathbf{A 2}^{+}$Ensaio clínico controlado e randomizado com intervalo de confiança, com análise de todos os fatores intervenientes de risco propostos; A2Ensaio clínico controlado e randomizado com intervalo de confiança, sem análise de todos os fatores intervenientes de risco propostos; $\mathbf{A 3}^{+}$Resultados terapêuticos do tipo "Tudo ou Nada" com análise de todos os fatores intervenientes de risco propostos; $\mathbf{A 3}^{-}$Resultados terapêuticos do tipo "Tudo ou Nada" sem análise de todos os fatores intervenientes de risco propostos; B1 ${ }^{+}$ Revisão Sistemática (com homogeneidade) de estudos de coorte, com análise de fatores intervenientes de risco propostos; B1 Revisão Sistemática (com homogeneidade) de estudos de coorte, sem análise de todos os fatores intervenientes de risco proposto; $\mathbf{B 2}^{+}$Estudo de coorte (incluindo ensaio clínico randomizado de menor qualidade), com análise de todos os fatores intervenientes de risco propostos; B2- Estudo de coorte (incluindo ensaio clínico randomizado de menor qualidade), sem análise de todos os fatores intervenientes de risco propostos; $\mathbf{B 3}^{+}$ Estudo observacional de resultados terapêuticos (outcome research) e estudo ecológico com análise de todos os fatores intervenientes de risco propostos; B3- Estudo observacional de resultados terapêuticos (outcome research) e estudo ecológico, sem análise de todos os fatores intervenientes de risco; $\mathbf{B 4}^{+}$Revisão sistemática (com homogeneidade) de estudos de casocontrole com análise de todos os fatores intervenientes de risco; B4 Revisão sistemática (com homogeneidade) de estudos de caso-controle sem análise de todos os fatores intervenientes de risco; C Relato de caso (incluindo coorte ou caso-controle de menor qualidade) com análise de 
todos os fatores intervenientes de risco; D Opinião desprovida de avaliação crítica, baseada em consensos, estudos fisiológicos, com materiais biológicos ou modelos animais.

No Quadro 12, verifica-se o predomínio dos estudos desta revisão sistemática no nível de evidência B2- (E3, E4, E6, E7, E10, E11, E12), o que significa ensaios clínicos de menor qualidade sem o controle de todas as variáveis que podem influenciar os resultados. Para essa classificação ser viabilizada, os ensaios clínicos não controlados e os controles históricos ou não concorrentes se enquadraram nesse tipo de desenho epidemiológico. Um único estudo (E9) foi de abordagem retrospectiva e está no nível de evidência B3-. Tais investigações são recomendadas pelo grau B, ou seja, Moderado.

Quatro estudos (E1, E2, E5 e E8) obtiveram o nível de evidência A2-, os quais são ensaios clínicos controlados randomizados, porém não controlaram todas as variáveis de risco para ISC consideradas no instrumento proposto. Esclareça-se, porém, que os E1 e E2 controlaram não somente a maioria dessas variáveis, como também as mais categorizadas como de maior risco, entre elas: duração e potencial de contaminação da cirurgia e susceptibilidade do paciente.

Tais estudos são considerados, sob esta avaliação, como de evidência forte e grau de recomendação A. 
Quadro 13 - $\quad$ Pontuação dos estudos randomizados incluídos para revisão sistemática, conforme Escala de Qualidade de Jadad. São Paulo, 2007.

\begin{tabular}{|l|c|c|c|c|}
\hline Estudo & Randomização & Cegamento & Exclusão/abandono & $\begin{array}{c}\text { Pontuação } \\
\text { total }\end{array}$ \\
\hline E1 & 02 & 02 & - & 04 \\
\hline E2 & 02 & 02 & 01 & 05 \\
\hline E5 & 02 & - & - & 02 \\
\hline E8 & 01 & - & - & 01 \\
\hline
\end{tabular}

Randomização: inserir 1 ponto se o estudo foi descrito como randomizado. Dê um ponto adicional se o método de randomização descrito foi adequado e deduza 1 ponto se foi inadequado

Cegamento: inserir 1 ponto se o estudo foi descrito como duplo-cego. Dê um ponto adicional se o método de cegamento descrito foi adequado e deduza 1 ponto se não foi adequado.

Exclusões/abandonos: inserir um ponto adicional se as retiradas e abandonos foram citadas.

Verifica-se que três estudos (E1, E2, E5) são ensaios clínicos com descrição adequada do método de geração de seqüência aleatória, discriminado o uso de envelopes selados, contendo números que foram abertos antes de iniciar a cirurgia (E2 e E5), ou numeração randomizada das mesas por dia de cirurgia (E1). Contudo, o estudo (E8) informa que é aleatório, mas não relata o método.

Tendo em vista o critério de randomização, que é uma forma de avaliar a qualidade dos estudos, porém não a única, deve ser associada à análise do cegamento a perda de participantes para constituir a Escala de Qualidade de Jadad et al. (1996). Nesta investigação, não foi possível aplicar essa escala com precisão, especificamente o critério cegamento, pois um estudo é duplo-cego quando o responsável pelo cuidado e o paciente não podem 
identificar a intervenção, o que não ocorre nos estudos incluídos, nos quais os cirurgiões são os responsáveis pelo tratamento cirúrgico, possibilitando a identificação do tipo de avental cirúrgico usado. Mesmo assim, no estudo E1 foi descrito que o microbiologista e a enfermeira que seguiu os pacientes no pós-operatório desconheciam a intervenção. E no estudo 2 também foi discriminado que a enfermeira que acompanhou o desfecho de ISC não estava consciente da intervenção. $\mathrm{O}$ único estudo que informa a perda de participantes e suas razões é o E2.

Pela análise da qualidade, especificamente em relação ao método, os melhores estudos são o E1 e o E2, que receberam a pontuação 4 ou 5. Enquanto que o E5 e o E8 são considerados de qualidade pobre.

O Quadro seguinte correlaciona os graus de evidência dos estudos com os resultados de suas investigações. 
Quadro 14 - Evidências dos estudos incluídos para revisão sistemática, conforme as escalas de avaliação e os resultados da investigação. São Paulo, 2007.

\begin{tabular}{|c|c|c|c|c|}
\hline $\begin{array}{c}\text { Evidência } \\
\text { Estudo }\end{array}$ & EQCIC & Jadad & $\begin{array}{l}\text { Diferença de } \\
\text { contaminação }\end{array}$ & $\begin{array}{c}\text { Diferença de } \\
\text { ISC }\end{array}$ \\
\hline E1 & A 2- & 04 & Não & Não \\
\hline E2 & A 2- & 05 & 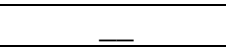 & Não \\
\hline E3 & B 2- & - & - & Sim \\
\hline E4 & B 2- & - & Sim & - \\
\hline E5 & A 2- & 02 & Não & $\overline{\overline{ }}$ \\
\hline E6 & B 2 - & - & 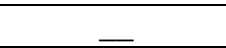 & $\mathrm{Sim}$ \\
\hline E7 & B 2- & - & Sim & - \\
\hline E8 & A 2- & 01 & Não & 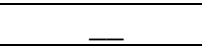 \\
\hline E9 & B 3- & $=$ & $\overline{-}$ & Não \\
\hline E10 & B 2- & - & $\overline{\mathrm{Sim}}$ & Não* \\
\hline E11 & B 2- & 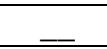 & $=$ & Sim \\
\hline E12 & B 2- & $=$ & Não & \\
\hline
\end{tabular}

* Para cirurgias de até 200 minutos de duração. Nas acima de 200 minutos houve diferença significativa de contaminação e ISC.

Houve coincidência dos estudos melhor avaliados pelas escalas EQCIC e JADAD. Eles são os E1 e E2. Observam-se, também, ensaios clínicos randomizados melhor avaliados pela escala EQCIC do que pela escala JADAD. Os E5 e E8 bem avaliados pela EQCIC não receberam boa pontuação na escala de JADAD.

Quanto aos desfechos, dos sete estudos que acompanharam a contaminação, quatro não obtiveram diferença significativa (E1, E5, E8, E12). Dos sete estudos que acompanharam ISC, quatro (E1, E2, E9, E10) não obtiveram diferença significativa também. Ressalte-se que o estudo E11, embora tenha obtido diferença de ISC, com menor freqüência para os descartáveis, os próprios autores não consideraram o resultado relevante, 
devido ao baixo número de cirurgias utilizadas. E o estudo E4, que apresentou diferença com maior redução da contaminação com descartável, citou, como nota final, ter recebido suporte financeiro pelo fabricante deste material.

Concluindo, a maioria dos estudos não obteve diferença significativa de contaminação e ou ISC, incluindo os estudos avaliados como de melhor qualidade de evidência pelas Escalas Jadad e EQCIC (E1, E2, E5, E8).

Os dados apresentados no Quadro 15 apresentam uma síntese de todos os estudos incluídos. 
Quadro 15 - Síntese panorâmica dos estudos incluídos para revisão sistemática, conforme escopo, método de investigação, resultado, avaliação EQCIC e JADAD. São Paulo, 2007.

\begin{tabular}{|c|c|c|c|}
\hline $\mathbf{E}$ & Escopo & Método & \begin{tabular}{|l|} 
Resultado \\
\end{tabular} \\
\hline \multirow[b]{2}{*}{1} & \multirow{2}{*}{$\begin{array}{l}\text { Contaminação microbiana da ferida operatória e } \\
\text { ISC em cirurgias eletivas limpas e ou com baixo } \\
\text { potencial de contaminação com uso de campos e } \\
\text { aventais de tecido algodão }\left(180 \text { fios/pol }{ }^{2}\right) \text { e } \\
\text { poliéster x não- tecido mistura de poliéster. } \\
\text { Ambos os casos reforçados na frente e nos } \\
\left.\text { antebraços ( } 270 \text { fios/pol }{ }^{2}\right)\end{array}$} & \multirow{2}{*}{$\begin{array}{l}\text { Ensaio clínico } \\
\text { controlado } \\
\text { randomizado }\end{array}$} & $\begin{array}{l}\text { Sem diferença significativa } \\
\text { das taxas de cultura positiva e } \\
\text { de ISC }\end{array}$ \\
\hline & & & $\begin{array}{l}\text { EQCIC: A2- } \\
\text { JADAD: } 04\end{array}$ \\
\hline \multirow{2}{*}{2} & \multirow{2}{*}{$\begin{array}{l}\text { ISC em cirurgias de artéria coronária com uso de } \\
\text { campos e aventais cirúrgicos de tecido x não- } \\
\text { tecido (tipo de material de ambos não } \\
\text { discriminado) }\end{array}$} & \multirow{2}{*}{$\begin{array}{l}\text { Ensaio clínico } \\
\text { controlado } \\
\text { randomizado }\end{array}$} & $\begin{array}{l}\text { Sem diferença significativa } \\
\text { de ISC }\end{array}$ \\
\hline & & & \begin{tabular}{|l|} 
EQCIC: A2- \\
JADAD: 05
\end{tabular} \\
\hline \multirow[t]{2}{*}{3} & \multirow[t]{2}{*}{$\begin{array}{l}\text { ISC em cirurgias limpas, limpas contaminadas e } \\
\text { contaminadas, realizadas em dois hospitais, com } \\
\text { uso de campos e aventais cirúrgicos de tecido } \\
\text { algodão musselina ( } 280 \text { fios/pol }{ }^{2}-\text { Hospital A e } \\
140 \text { fios/pol }^{2} \text { - Hospital B ) x não tecido } \\
\text { spunbonded olefin }\end{array}$} & \multirow[t]{2}{*}{$\begin{array}{l}\text { Controle } \\
\text { histórico ou não } \\
\text { concorrente }\end{array}$} & $\begin{array}{l}\text { A taxa de ISC com o uso de } \\
\text { avental descartável foi de } 2 \text {, } \\
27 \% \text { enquanto que com o uso } \\
\text { de reutilizável foi de } 6,41 \% \text {; } \\
\text { portanto houve diferença } \\
\text { significativa. As taxas de ISC } \\
\text { em cirurgias limpas foram de } \\
1,98 \% \text { quando utilizou } \\
\text { aventais descartáveis versus } \\
4,42 \% \text { com a utilização de } \\
\text { reprocessável. Já em cirurgias } \\
\text { limpas contaminadas, a taxa } \\
\text { de infecção cirúrgica foi de } \\
1,98 \% \text { com o uso de } \\
\text { descartável versus 10,89\% } \\
\text { com o uso de reprocessável. }\end{array}$ \\
\hline & & & \begin{tabular}{|l|} 
EQCIC: B2- \\
JADAD: não classificável
\end{tabular} \\
\hline 4 & $\begin{array}{l}\text { Contaminação microbiana do ar e da ferida } \\
\text { operatória em cirurgias de correção de escoliose } \\
\text { idiopática, dividido em } 5 \text { fases: } \\
\text { 1) ventilação convencional + uniforme privativo } \\
\text { de algodão + aventais e campos de algodão + } \\
\text { máscaras e toucas descartáveis } \\
\text { 2) ventilação convencional + uniforme privativo } \\
\text { de algodão + campos e aventais de viscose com } \\
\text { camada interna de poliamida e reforço na frente e } \\
\text { mangas, máscaras e toucas descartáveis. } \\
\text { 3) ventilação convencional, uniforme privativo de } \\
\text { polipropileno; campos e aventais de viscose com } \\
\text { camada interna de poliamida e reforços nas } \\
\text { mangas e frente, máscara e toucas descartáveis. }\end{array}$ & $\begin{array}{l}\text { Ensaio clínico } \\
\text { não controlado }\end{array}$ & $\begin{array}{l}\text { Sem variação de } \\
\text { contaminação nos períodos } 1 \\
\text { e } 2 \text { nos quais a ventilação e o } \\
\text { uniforme privativo eram } \\
\text { convencionais, diferindo } \\
\text { somente os aventais e campos } \\
\text { cirúrgicos que no período } 1 \\
\text { era de algodão e no período } 2 \\
\text { era descartável. Menos } \\
\text { contaminação foi registrada } \\
\text { nos períodos } 3,4 \text { e } 5, \\
\text { comparados com os períodos } \\
1 \text { e 2. } \\
\text { Conflito de interesse }\end{array}$ \\
\hline
\end{tabular}




\begin{tabular}{|c|c|c|c|}
\hline & $\begin{array}{l}\text { 4) ventilação ultra-limpa, uniforme privativo e } \\
\text { campos de algodão, aventais integrados ao } \\
\text { sistema helmet (capacete), máscara e toucas } \\
\text { helmet com sistema de exaustão } \\
\text { 5) ventilação ultra-limpa, uniforme privativo de } \\
\text { algodão, campos e aventais descartáveis de } \\
\text { viscose com camada interna de poliamida e } \\
\text { reforços nas mangas e frente com reforço, toucas } \\
\text { + máscara helmet sistema de exaustão. }\end{array}$ & & $\begin{array}{l}\text { EQCIC: B2- } \\
\text { JADAD: não classificável }\end{array}$ \\
\hline \multirow[b]{2}{*}{5} & \multirow{2}{*}{$\begin{array}{l}\text { Contaminação microbiana do ar e da ferida } \\
\text { operatória em cirurgias de substituição primária } \\
\text { de joelhos com uso de avental sistema BES (Body } \\
\text { Exhaust Suit), avental De Puy® e ventilação UCA } \\
\text { (fluxo vertical laminar ultralimpo) x avental } \\
\text { sistema Rotecno (Dunfermline®) de spunlaced e } \\
\text { mesmo sistema de ventilação }\end{array}$} & \multirow{2}{*}{$\begin{array}{l}\text { Ensaio clínico } \\
\text { controlado } \\
\text { randomizado }\end{array}$} & $\begin{array}{l}\text { Sem diferença significativa } \\
\text { de contaminação microbiana } \\
\text { da ferida operatória. }\end{array}$ \\
\hline & & & \begin{tabular}{|l|} 
EQCIC: A2- \\
JADAD: 02
\end{tabular} \\
\hline \multirow[t]{2}{*}{6} & \multirow[t]{2}{*}{$\begin{array}{l}\text { ISC em cirurgias limpas e limpas contaminadas } \\
\text { como uso de campos e aventais cirúrgicos de } \\
\text { tecido de algodão }\left(280 \text { fios } / \mathrm{pol}^{2}\right) \times \text { não- tecido } \\
\text { spunlaced, em períodos alternados. }\end{array}$} & \multirow[t]{2}{*}{$\begin{array}{l}\text { Controle } \\
\text { histórico ou não } \\
\text { concorrente. }\end{array}$} & $\begin{array}{l}\text { ISC significativamente menor } \\
\text { com uso de não- tecido em } \\
\text { cirurgias limpas e limpas } \\
\text { contaminadas com o uso de } \\
\text { descartáveis spunlaced versus } \\
\text { algodão. }\end{array}$ \\
\hline & & & $\begin{array}{l}\text { EQCIC: B2- } \\
\text { JADAD: não classificável }\end{array}$ \\
\hline 7 & $\begin{array}{l}\text { Contaminação da ferida operatória com } \\
\text { microesferas de albumina em cirurgias } \\
\text { ortopédicas com uso de campos e aventais de } \\
\text { tecido x não-tecido Barrier® }\end{array}$ & $\begin{array}{l}\text { Controle } \\
\text { histórico ou não } \\
\text { concorrente. }\end{array}$ & $\begin{array}{l}\text { Recuperação de microesferas } \\
\text { em todas as feridas com uso } \\
\text { de material de tecido e seu } \\
\text { aumento proporcional à } \\
\text { duração da cirurgia e não } \\
\text { recuperação com uso de não- } \\
\text { tecido. } \\
\text { EQCIC: B2- } \\
\text { JADAD: não classificável }\end{array}$ \\
\hline \multirow{2}{*}{8} & \multirow{2}{*}{$\begin{array}{l}\text { Contaminação microbiana da ferida e do ar da SO } \\
\text { em cirurgias de artéria coronária abertas e eletivas } \\
\text { com uso de uniforme privativo, campos e aventais } \\
\text { de tecido convencional de algodão x de não- } \\
\text { tecido (uniforme privativo de polipropileno e } \\
\text { aventais Mönlyke® }{ }^{\circledR} \text { reforçado com filme plástico } \\
\text { na frente e mangas e campos plásticos laminados } \\
\text { impermeáveis com auto-adesivo nas bordas). }\end{array}$} & \multirow{2}{*}{$\begin{array}{l}\text { Ensaio clínico } \\
\text { controlado } \\
\text { randomizado. }\end{array}$} & $\begin{array}{l}\text { Sem diferença significativa } \\
\text { de crescimento bacteriano na } \\
\text { ferida operatória. }\end{array}$ \\
\hline & & & $\begin{array}{l}\text { EQCIC: A2- } \\
\text { JADAD: } 01\end{array}$ \\
\hline 9 & $\begin{array}{l}\text { ISC em cirurgias gerais de animais (cães e gatos) } \\
\text { entre campos e aventais de tecido de algodão } \\
\text { musselina } 140 \text { fios } / \mathrm{pol}^{2} \times \text { não-tecido de } \\
\text { polipropileno spunlaced }\end{array}$ & $\begin{array}{l}\text { Observacional } \\
\text { de resultado } \\
\text { terapêutico }\end{array}$ & $\begin{array}{l}\text { Diferença não significativa de } \\
\text { ISC entre os grupos de } \\
\text { material de barreira de } \\
\text { algodão versus descartável. } \\
\text { EQCIC: B3- } \\
\text { JADAD: não classificável }\end{array}$ \\
\hline
\end{tabular}


Contaminação microbiana da ferida operatória e

ISC em cirurgias limpas, limpas contaminadas,

10 contaminadas e sujas com uso de campos e

aventais de tecido não-tecido FABRIC $450 \AA \mathrm{x}$ tecido de algodão.

11 contaminadas e sujas com o uso de campos e aventais descartáveis versus têxteis.
Ensaio clínico controlado não randomizado

Crong

Ensaio clínico
controlado não
randomizado

Sem diferença significativa de ISC em cirurgias de duração breve (menor 100 minutos) e média (100 a 200 minutos).Nas intervenções de longa duração (mais de 200 minutos) não teve ISC com o uso de TNT FABRIC 450® versus $33,3 \%$ de ISC com o uso de algodão. Houve contaminação microbiana em $16 \%$ das intervenções com o uso de descartável versus $24 \%$ com o uso de algodão. EQCIC: B2-

JADAD: não classificável

Sem diferença significativa de ISC devido o baixo número de cirurgias (conforme os autores) EQCIC: B2JADAD: não classificável Sem diferença significativa de contaminação microbiana da ferida operatória com o uso de aventais e uniformes privativo de não tecido Barrier $450 ®$ versus algodão. EQCIC: B2-

JADAD: não classificável 


\section{DISCUSSÃO}

A proposta de buscar evidências sobre o uso de aventais cirúrgicos, segundo seu material de confecção, no controle da contaminação da ferida operatória e ou ISC, teve a finalidade de garantir a segurança dos pacientes submetidos a cirurgias e também facilitar a tomada de decisão dos enfermeiros, médicos e administradores hospitalares na aquisição desses materiais de barreira. Diante do exposto, cabe aos profissionais de saúde se embasar em evidências para uma prática segura, avaliando a qualidade dos estudos e sua aplicabilidade.

O embasamento para esta evidência pautou-se na busca e análise, por meio de revisão sistemática, de pesquisas básicas já realizadas, as quais totalizaram 12 publicações, encontradas em bases eletrônicas, principalmente, o PubMed/MEDLINE (Quadro 5). As buscas manuais, a partir das referências dos estudos encontrados e da revista da Sociedade Brasileira de Enfermagem em Centro Cirúrgico, Recuperação Anestésica e Central de Material e Esterilização, não apresentaram pesquisas sob este enfoque. Estas pesquisas têm origem predominantemente européias, seguidas pelas americanas e canadenses. Não foi encontrado nenhum estudo nacional (Quadro 6).

Todas as pesquisas incluídas foram desenvolvidas em situação real de cirurgia em humanos, com exceção de uma delas, que utilizou como populações, cães e gatos (E9). 
As pesquisas foram realizadas principalmente na década de 80 do século XX (Quadro 6), período de impulso vertiginoso do uso de materiais de confecção de não-tecidos na área hospitalar. Tal fato constata que o desenvolvimento de novas tecnologias de equipamentos e de materiais médico-hospitalares leva à necessidade de pesquisas que justifiquem sua efetividade e eficiência.

Os principais escopos dos estudos incluídos foram a avaliação da contaminação microbiana da ferida operatória e ou da ISC, relacionadas ao material de confecção dos aventais cirúrgicos (Tabela 3). Alguns estudos tiveram mais de um escopo, como avaliação de custos, manuseio e conforto dos aventais ou contaminação microbiana da pele e ou do ar da SO.

Embora o componente específico de análise desta revisão seja o avental cirúrgico, somente um estudo (E5) utilizou-o isoladamente como objeto de intervenção. Os demais correlacionaram-no principalmente com campos cirúrgicos (E1, E2, E3, E6, E7, E9, E10, E11) (Tabela 1). Tal fato denota a dificuldade de isolar um único fator ou variável de risco de contaminação e ou ISC, dentre os diversos outros existentes, mesmo aqueles que dizem respeito especificamente a barreiras microbiológicas mecânicas, como é o caso da paramentação cirúrgica. Antecipe-se, então, que as conclusões de evidência, conforme são discutidas adiante, não podem considerar apenas o efeito isolado do avental cirúrgico, e, sim, enquanto correlacionado a um ou mais componentes de barreira, principalmente, o campo cirúrgico.

Outra questão diz respeito aos tipos de materiais de confecção dos aventais e outros componentes da paramentação cirúrgica investigados (Quadro 7). 
Não houve coincidência entre os estudos sob análise, ou seja, não houve utilização dos mesmos materiais, seja para grupos de tecido, seja de não-tecido. Além disto, os tipos de materiais não foram sempre minuciosamente descritos, ora restringindo-se ao nome comercial daqueles de não-tecido e ora não discriminando a composição dos de tecido. Com relação aos de tecido, a composição das tramas foi variada ou, por vezes, nem mesmo foi descrita. Por fim, nenhum estudo sob análise considerou frequiências de reuso, ou seja, de reprocessamentos dos aventais de tecido.

Vários estudos já comprovaram o desgaste e a perda progressiva de capacidade de barreira de materiais de tecido, de acordo com o número de reprocessamentos. Em Leonas (1998), o efeito da lavagem sobre as propriedades de barreira de cinco aventais cirúrgicos de tecidos reutilizáveis foi avaliado com zero, vinte e cinco e cinqüenta lavagens. Como resultado constatou-se que quanto maior o número de lavagens, tanto maior o desgaste do tecido, reduzindo sua habilidade de repelir líquidos e de prevenir passagem de microrganismos, excetuando um tipo de tecido, que não aumentou sua permeabilidade a bactérias, depois das lavagens.

A capacidade de barreira também foi analisada em oito aventais cirúrgicos disponíveis comercialmente, sendo cinco descartáveis e três reutilizáveis. Testes foram usados para avaliar várias características destes materiais de barreira, inclusive a resistência à penetração de microrganismos. Todos os de tecidos permitiram a passagem de líquidos e bactérias e quatro tipos de não-tecidos preveniram a migração de bactérias (LEONAS, JINKINS, 1997).

Por outro lado, estudo brasileiro que avaliou a barreira microbiana de campos de tecido utilizados para embalagens de artigos odonto-médico- 
hospitalares obteve efetiva barreira microbiana, desde o primeiro uso e até o sexagésimo quinto reprocessamento (lavagens e esterilizações). O tecido destes campos era duplo e composto de $100 \%$ algodão, sarja T1, correspondendo à padronização da Associação Brasileira de Normas Técnicas (ABNT), para embalagens de artigos. O teste baseou-se na metodologia alemã, DIN (Deutches Institut fur Neamurg), n.58.953-parte 6, utilizada para testar a barreira microbiana de embalagens. O procedimento do teste consistiu em instilar $100 \mu \mathrm{l}$ de suspensão bacteriana de Staphylococcus aureus ATCC $^{5}$ n.25923 $10^{7-8}$ ufc/ml sobre a embalagem e checar a passagem de microrganismos testes para uma Placa de Petri agar-sangue, simulando a condição prática do dia-a-dia (RODRIGUES, 2000) .

Outro estudo brasileiro, realizado com campos cirúrgicos simples de $100 \%$ algodão, segundo a padronização da ABNT, simulando sua utilização durante o ato operatório, constatou que a partir do $6^{\circ}$ reprocessamento ocorreu a quebra da barreira microbiana. Os campos cirúrgicos eram contaminados, lavados e esterilizados. Após a esterilização foram realizados os testes microbiológicos. Utilizou-se a metodologia alemã DIN (Deutches Institut fur Neamurg) para os testes de barreira, que consistiu em instilar $100 \mu$ de suspensão microbiana diluída contendo o microrganismo Staphylococcus aureus nas quatro extremidades do campo simples. No verso do material era colocada uma placa de Petri e então os campos eram deixados em fluxo laminar até a secagem completa do mesmo; em seguida, as placas de Petri eram retiradas e substituídas por placas de Petri Agarsangue com o objetivo de verificar se ocorreu ou não a passagem de microrganismos pelo campo (BURGATTI, POSSARI, MODERNO, 2004). 
Pissiotis et al. (1997) testaram alguns tipos de materiais de confecção de aventais e obtiveram os seguintes níveis de passagem sangue: 1) aventais reutilizáveis - 90\%;2) aventais descartáveis de uma única lâmina - 11\%; 3) aventais descartáveis reforçados $-3 \%$.

A partir de tais estudos é possível constatar que a capacidade de barreira microbiológica de materiais de embalagem e de paramentação está diretamente relacionada com a estrutura de sua composição. Além disto, a passagem microbiana não se restringe apenas aos reutilizáveis, mas também aos descartáveis. Há, na verdade, várias formas e tipos de confecção de não-tecido, conforme já descrito no capítulo sobre abordagens teóricas, item 2.1.7, desta revisão. Alguns podem, até mesmo, ser mais porosos do que os tecidos, como é o caso daqueles utilizados para confecção de gorros, máscaras e propés.

Ao contrário do que ocorre com campos para embalagens de artigos não há, até o momento, normas técnicas ou exigências governamentais nacionais que determinem a capacidade de barreira para componentes da paramentação cirúrgica, inclusive aventais. Existem, apenas, recomendações genéricas, sendo mais reconhecida aquela apresentada nas Diretrizes do C.D.C. para controle e prevenção de infecção do sitio cirúrgico, sob categoria de evidência IB, onde consta: os materiais empregados na confecção do avental cirúrgico devem assegurar uma barreira efetiva, mesmo quando umedecidos (MANGRAM et al., 1999).

Beck e Collette (1953) sugerem que os aventais devem ser testados nos laboratórios. Testes laboratoriais, porém, não reproduzem as situações reais de 
cirurgia. Outros fatores precisam ser considerados, entre eles: tipo e duração da cirurgia, possibilidade ou não de umidade e de contato com o campo operatório, condições de seu uso. Essas e outras situações determinam níveis variados de pressão e estresse, sendo que, segundo Pissiotis et al. (1997), determinadas áreas sofrem mais, como abdome, tórax e antebraços. Na prática, porém, não há como monitorálos.

Os aventais podem ser reforçados com membranas impermeáveis, como o polietileno, em locais com elevada pressão pela fricção ou de maior contato com a área operatória. Telford e Quebbeman (1993) sugerem-nos para cirurgias com perda de sangue acima de $100 \mathrm{ml}$ e duração que excede 2 horas ou envolvendo a região abdominal.

A maior vantagem dos não-tecidos é a de que seus fabricantes podem realizar testes minuciosos, com garantia das diferentes capacidades de barreira. Sendo assim, há que se questionar se orientações e condições para uso de materiais de tecido também não poderiam ser estabelecidas pelos seus fabricantes. Por exemplo, conforme Stanewick e Kogut (1993), o número máximo de re-usos para cada produto, baseados em testes de laboratório que especifiquem os ciclos de lavagem, secagem e esterilização, com a concomitante documentação de características de vida útil dos tecidos, conforme realização dos ciclos. Além disso, o ciclo de lavagem do tecido deve ser descrito com os seguintes parâmetros: tempo para cada lavagem, níveis de água, temperatura da água, recomendações de lavagens específicas antes do uso para remover finalizações aplicadas ao tecido durante a 
confecção e recomendações de lavagem dos materiais de barreira separadamente das outras roupas de cama para minimizar o acúmulo de fiapos dos outros tecidos.

O enxágüe também é parte essencial do reprocessamento, objetivando remover sabão e detergente. Se resíduos de tensoativos são deixados nos tecidos, eles podem temporariamente reduzir as suas características de repelência. Devido, porém, à variedade de equipamentos de lavagem disponíveis, não é possível ditar um único ciclo de reprocessamento aplicável para todas as circunstâncias (STANEWICK, KOGUT, 1993).

Laufman (1982) recomenda que os campos e aventais confeccionados em algodão com 140 fios e materiais de não-tecido sem reforços deveriam ter um aviso: “este material não é impermeável a bactérias, especialmente quando molhados". E, nos aventais e campos de tecidos deve-se anotar, de alguma maneira, o número de reprocessamentos.

Apesar da importância do detalhamento do reprocessamento e sua relação com o desgaste dos tecidos reutilizáveis, os estudos desta revisão, conforme visto, não informaram nem o tempo de uso dos aventais de tecido, tampouco os processos utilizados para lavagem, secagem e esterilização.

É evidente que materiais mais porosos, sobretudo de tecido, constituem barreiras menos efetivas, principalmente sob condições úmidas. É uma questão polêmica, entretanto, reconhecer se sua perda de barreira pela umidade constitui condição direta para a passagem de microrganismos. O tamanho da molécula de água é muito menor do que a grande maioria das bactérias conhecidas, com exceção dos vírus. Estudo brasileiro, de Moriya (2005), obteve manutenção de 
esterilidade a bactérias de materiais molhados / úmidos após autoclavação e armazenamento.

Ainda que ocorra a passagem de microrganismos é preciso comprovar se eles realmente atingem a área operatória. E, se atingem, de que modo isso ocorre, se espontaneamente ou se necessita alguma pressão.

A busca desta resposta é, afinal, a finalidade desta revisão. Ao que parece, a resposta tende a ser negativa, ao considerarmos os resultados dos estudos incluídos. Dentre todos os que analisaram como desfecho a contaminação (E1, E4, E5, E7, E8, E10, E12), três obtiveram diferenças (E4, E7, E10). E, dentre os que analisaram a ISC (E1, E2, E3, E6, E9, E10, E11), somente dois (E3, E6), obtiveram diferença. Esta diferença referiu-se à maior incidência de contaminação e ISC para materiais de tecido.

A conclusão possível, a partir dos resultados da grande maioria destes estudos, seria a de que não há evidência de contaminação e ocorrência de ISC, independentemente do tipo de material de confecção dos aventais e campos cirúrgicos.

Sabidamente, porém, os resultados não são suficientes para definir tal evidência. É preciso reconhecer a qualidade das investigações desenvolvidas, conforme a proposta desta revisão sistemática. Esta qualidade foi buscada de dois modos: quanto ao tipo de investigação e à validade interna.

Os tipos de investigações mais freqüentemente utilizados foram: ensaio clínico controlado randomizado (33,3\%), correspondendo aos estudos E1, E2, 
E5, E8. Empatado em freqüência $(33,3 \%)$ veio o controle histórico ou não concorrente, nos estudos E3, E6, E7, E11. Seguiram-se o ensaio clínico não controlado (sem grupo controle), nos estudos E4 e E12, o ensaio clínico controlado não randomizado (E10) e o observacional de resultado terapêutico (E9).

Os ensaios clínicos controlados aleatórios, após as revisões sistemáticas de ensaios clínicos com metanálise, são considerados os melhores tipos de investigações, pelos principais centros de práticas baseadas em evidência e diretrizes de recomendações clínicas. Sob esta classificação, os estudos E1, E2, E5 e E8 são considerados, portanto, de melhor qualidade que os demais.

Mesmo nos melhores tipos de investigação, porém, erros sistemáticos de seleção, condução, seguimento e detecção podem ocorrer, determinando vieses (bias) nos resultados ou inferências. Tais vieses interferem na validade interna dos estudos. Conforme o Handbook da Colaboração Cochrane (2001), eles dizem respeito a: a) diferenças significativas nos grupos de comparação (viés de seleção), cuja randomização é usada para prevenir esse tipo de erro; b) cuidados iguais ou mesma exposição a todos os outros fatores, além da intervenção de interesse (viés de condução), cujo mascaramento é usado para evitar esse tipo de erro; c) perdas ou exclusões de pessoas incluídas no estudo (viés de seguimento) que devem ser explicitados; d) modo de verificação dos desfechos (viés de detecção ou diagnóstico). A análise de tais fatores diz respeito à validade interna do estudo.

A Escala de Jadad (1996), conforme descrita no capitulo 2, item 2.3.2, avalia os vieses de seleção e de seguimento, considerando os critérios de randomização, cegamento e razões para perda ou exclusão de participantes (quando 
houver). E, conforme já visto, a pontuação máxima é 5, sendo considerados como de alta qualidade aqueles que obtêm pontuação igual ou acima de 3. A partir destes critérios, somente os estudos E1 e E2 são considerados de alta qualidade, por terem obtido pontuações 5 e 4, respectivamente. Os demais obtiveram abaixo de 3 (Quadro 13). Ressalve-se, nesta avaliação, o critério cegamento, devido à impossibilidade dos responsáveis pelo tratamento cirúrgico desconhecerem a intervenção intra-operatória.

Já, os vieses de condução, que dizem respeito à garantia de cuidados iguais ou mesma exposição a todos os outros fatores, além da intervenção de interesse, no caso desta revisão se referem, fundamentalmente, ao controle das variáveis de risco para contaminação e ou ISC, conforme já apresentados no capítulo 2, desta revisão.

Nos resultados desta análise, os estudos E1 e E2, já avaliados como de melhor qualidade quanto ao tipo de investigação e vieses de seleção e seguimento, foram também os que controlaram maior quantidade de variáveis extrínsecas e intrínsecas - doze no total, seguidos pelo E8 (9), E12 (8), E3, E5 e E6 (7) (Quadros 9 e 10).

Dentre as variáveis controladas pelos E1 e E2 encontram-se aquelas recomendadas com melhores categorias de evidência pelo CDC, além dos fatores de predição de risco, que são: duração da cirurgia, tipo de cirurgia e pontuação ASA ou identificação de susceptibilidade individual pré-existentes (diabetes, estado nutricional, ASA).

Dentre as variáveis extrínsecas, aquelas mais controladas pelos estudos foram tipo de cirurgia (12), o uso de antibioticoprofilaxia (9), duração da 
cirurgia e equipe cirúrgica (7). O preparo pré-operatório da pele, recomendação de categoria IB pelo C.D.C., foi citado por apenas 4 estudos. Variáveis relacionadas com o controle de contaminação do ambiente foram controladas pela minoria dos estudos.

Quanto ao tipo de cirurgia, apesar de ter ocorrido controle de sua distribuição entre os grupos e serem da mesma especialidade, porém nem sempre eram do mesmo tipo e potencial de contaminação. Cirurgias de tipos diferentes, ainda que de mesma especialidade, determinam duração e condução diferentes, podem acarretar variações da permeabilidade das barreiras microbiológicas e da carga de contaminação microbiana. Já, cirurgias de mesmo tipo e duração semelhantes, porém realizadas em locais com microbiota residente, esta passa a ser, sabidamente, a principal fonte de contaminação da ferida e de ISC (LACERDA, 2003), dificultando estabelecer o valor isolado do objeto sob intervenção.

As variáveis intrínsecas, relacionadas à susceptibilidade individual para o desenvolvimento da ISC, foram controladas por poucos estudos. As mais freqüentemente consideradas - idade (6) e sexo (6) - constituem, justamente, as que não apresentam evidências científicas (LACERDA, 2003). Já, as condições individuais de saúde, fatores considerados relevantes, foram controladas pela minoria dos estudos: avaliação de doenças pré-existentes (E1, E2), estado nutricional (E1), índice de massa corpórea (E2) e ASA (E1) (Quadros 9 e 10).

Somente os estudos E1 e E2 realizaram análise estatística de equivalência dessas variáveis entre os grupos controle e experimental, após a randomização (Tabela 6). 
Na ausência de estratificação, uma outra forma de oferecer maior chance de distribuição eqüitativa dessas variáveis entre os grupos controle e experimental é utilizar grandes populações. Nos resultados, porém, isso não ocorreu, ou seja, estudos que mais controlaram variáveis de risco, também foram os que apresentaram maiores populações (Quadro 11).

Quanto ao desfecho, em uma primeira consideração, todos os estudos atenderam à questão desta revisão, ao terem analisado contaminação e ou ISC. A análise apenas da contaminação apresenta a vantagem de não ser necessário controlar diversas variáveis que constituem fatores de risco de ISC em cirurgia, além da presença de microrganismos. Entre estes fatores, destacam-se aqueles intrínsecos, ou seja, que dizem respeito à susceptibilidade individual do paciente. Por outro lado, o desfecho final de interesse é, obviamente, a ISC, uma vez que a presença de contaminação não é garantia suficiente para sua evolução. O mais desejável, portanto, seria a análise dos dois tipos de desfechos.

Apenas dois estudos analisaram concomitantemente a contaminação e a ISC: o E1, avaliado até o momento como um dos de melhor qualidade, e o E10. O outro estudo até agora analisado como de melhor qualidade E2 - analisou apenas a ISC, assim como os E3, E6, E9 e E11. Os E4, E5, E7, E8 e E12 analisaram apenas a contaminação da ferida (Tabela 3).

O recurso para análise dos desfechos foi sempre o mesmo para todos os participantes de cada estudo. Houve, porém, muitos tipos de análises entre os estudos. A ferida operatória foi o local de coleta de material para cultura em todos os estudos que analisaram a contaminação, variando, porém, os métodos para coleta 
e leitura da cultura microbiana. A presença de pus foi o principal critério para o diagnóstico de ISC (E1, E3, E9, E11). Outros critérios foram: leucograma (E10), deiscência de FO (E9), reoperação (E11), eritema, edema, dor (E9), Score Assepsis (E2), Conselho Nacional de Pesquisa (E3, E6), uso de antibiótico (E10).

Critérios diferentes para diagnóstico de ISC podem determinar diferenças de sua freqüência. Somente o estudo E5 utilizou os critérios mais amplamente conhecidos e utilizados atualmente, que são os do C.D.C. (MANGRAM et al., 1999), descritos no capítulo 2, desta revisão. Provavelmente isto ocorreu porque este estudo foi o único estudo realizado após a publicação desses critérios.

No outro recurso utilizado para avaliar estes estudos, que associou o controle de variáveis de risco para ISC com os níveis de evidência do Centro de Medicina Baseada em Evidências de Oxford, adaptada por Nobre e Bernardo (2006), a maioria deles foi classificada na categoria de evidência B, ou seja, moderada, variando de B2- (E3, E4, E6, E7, E10, E11, E12) a B3- (E9). Apenas quatro são fortemente recomendados, por terem se enquadrado no grau de recomendação A, sendo o nível de evidência A2- (E1, E2, E5, E8).

Os estudos E1 e E2 novamente aparecem classificados na melhor categoria de recomendação (A). Aparecem também no melhor nível de evidência os estudos E5 e E8 (A2-).

É possível considerar o E1 o melhor de todos, uma vez que além de todas as qualidades dos demais, ainda analisou os dois tipos de desfechos: contaminação da FO e ISC. 
Considerando, agora, os resultados destes quatro melhores estudos, os E1, E2, E5 e E8, que analisaram a contaminação da ferida operatória, não obtiveram diferença significativa entre uso de material de tecido e não-tecido. E os estudos E1 e E2, que analisaram a ISC, também não obtiveram diferença significativa de sua ocorrência entre uso de material de confecção de tecido e nãotecido.

Note-se, porém, que somente o E5 investigou isoladamente o avental cirúrgico. Os E1 e E2 investigaram o avental com os campos cirúrgicos e o E8 utilizou campos cirúrgicos e uniformes privativos conjuntamente.

Com base nestes resultados é possível afirmar, com forte evidência, de que não há diferença significativa de contaminação e ISC entre uso de campos e aventais cirúrgicos de tecido e não-tecido em cirurgias. Não é possível garantir, porém, para o avental cirúrgico isoladamente. A busca desta evidência isolada dependerá de realização de estudo de intervenção bem conduzido e controlado.

Constata-se, também a não possibilidade de realizar metanálise desta revisão, tendo em vista a não existência de pelo menos dois estudos semelhantes que sejam coincidentes tanto com relação ao mesmo tipo de investigação, quanto aos objetos sob intervenção, desfechos, análise dos resultados, métodos para diagnóstico de ISC, entre outros.

Finalmente, esta revisão sistemática permite reconhecer não somente problemas de construção e de validade interna dos estudos encontrados, como também a necessidade de considerar a especificidade de pesquisas na área de controle de infecção hospitalar. Ela diz respeito, principalmente, à dificuldade de 
controle dos diversos fatores de risco - intrínsecos e extrínsecos - envolvidos, além do objeto sob intervenção.

Recomenda-se que estudos desta natureza, além de utilizar os tipos investigações melhor categorizados, seria desejável que definissem, estratificassem, previamente à randomização, grupos intervenção e controle os mais semelhantes possíveis quanto às variáveis de risco. Ou, então, análise estatística de sua distribuição entre os grupos controle e experimental.

As principais variáveis a serem controladas são as que seguem:

- Tipo de cirurgia: favorece semelhanças de técnica e duração das cirurgias.

- Potencial de contaminação da cirurgia: mesmo potencial e, preferentemente, limpas ou potencialmente contaminadas, nas quais são mais reduzidas as chances de contaminação da ferida pela microbiota do paciente.

- Ambiente da SO: semelhanças ou mesmas salas de operações, sistema de climatização do ar e quantidade e movimentação de pessoas favorecem equivalência de controle de contaminação do ar.

- Equipe cirúrgica: a mesma equipe favorece técnica e duração semelhantes das cirurgias.

- Antibioticoprofilaxia: dizem respeito não apenas ao uso de drogas equivalentes, mas também o mesmo momento de indução, dosagem, via e período de duração.

- Variáveis de riscos intrínsecos: consideração de fatores individuais do paciente, como o índice ASA. 
- Preparo pré-operatório: que inclui tricotomia, banho e antisepsia da pele.

- Diagnóstico de ISC: utilização de critério amplamente reconhecido.

- Acompanhamento pós-cirurgia: considerando os prazos amplamente considerados para sua evolução.

- Coleta e análise de cultura microbiológica: considerar critérios cientificamente fundamentados ou sua validação prévia.

Os processos de randomização e cegamento devem ser descritos e corresponder àqueles melhor considerados, como o da Escala de Jadad (JADAD et al, 1996). As perdas e ou exclusões devem ser citadas e explicitadas. Após a randomização e as intervenções é necessária demonstração de equivalência de população entre os grupos e de variáveis significativas com possíveis interferências nos resultados, como é o caso dos fatores de risco citados, por meio de análise estatística de significância.

Finalmente, a hipótese inicialmente considerada nesta revisão sistemática foi refutada, por não ter havido evidência de que barreiras de não-tecido são superiores na redução da contaminação da ferida operatória e da ISC. 


\section{CONCLUSÃO}

A efetividade isolada do uso de avental cirúrgico, conforme os tipos de materiais para sua confecção, no controle da contaminação microbiana da ferida operatória e da infecção do sítio cirúrgico depende de mais pesquisas experimentais bem delineadas e com rigorosos controles que garantam sua validade interna.

Considerando a amostra desta revisão sistemática (12 estudos), destacaram-se dois estudos (E1, E2) de forte evidência de recomendação. Ambos, porém, se referem aos aventais e campos cirúrgicos, conjuntamente, concluindo sobre a não diferença de contaminação e ou infecção do sítio cirúrgico entre materiais de tecido e não-tecido. Além de terem utilizado o delineamento de pesquisa mais considerado para estudos de intervenção - randomizado, apresentam uma alta validade interna, constatada pelo uso de duas escalas de qualidade: Jadad (1996) e de Controle de Infecção Cirúrgica (EQCIC), adaptada de Nobre e Bernardo (2006).

A não semelhança de forma de intervenção e de controle de variáveis entre os estudos analisados não possibilitou a metanálise.

A contribuição desta investigação para a implementação da prática baseada em evidências, especificamente buscando a resposta desta pergunta de pesquisa, que independe tanto das crenças e preferências do paciente quanto das experiências do profissional enfermeiro, mostrou-se necessária para apontar qualidade, lacunas e falhas nos artigos analisados. Mas também permite ao 
pesquisador avaliação prévia de variáveis externas explicitadas anteriormente, que podem influenciar os resultados, nos próximos estudos.

Além disso, esta investigação corrobora a prática científica, quando discrimina todos os passos usados para localizar, selecionar e interpretar a literatura científica nas bases de dados eletrônicas ou não, possibilitando sua reprodução. 


\section{REFERÊNCIAS}

AHAMAD, F.K.; SHERMAN J.S.; HAGGLUND, K.H. The use and failure rates of protective equipment to prevent blood and bodily fluid contamination in the obstetric health care worker. Obstetric. Gynecol, v. 2, n. 1, p. 131-36, 1998.

ASSOCIAÇÃO BRASILEIRA DE INDÚSTRIAS DE NÃO-TECIDOS E TECIDOS TÉCNICOS (ABINT). Disponível em: <http:// www.abint.org>. Acesso em $12 \mathrm{de}$ nov. de 2006.

ASSOCIAÇÃO BRASILEIRA DE NORMAS TÉCNICAS. NBR 13370. Rio de Janeiro, 2002.

ASSOCIATION OF THE NONWOVEN FABRIC INDUSTRY (INDA). Facts and fiction about single-use and reusable drapes and gowns, p. 1-6, 1993.

ASSOCIATION OF OPERATING ROOM NURSING. Proposed recommended practices for uses and selection of barrier material for surgical gowns and drapes. AORN. J, v. 62 n. 3, p. 449-53, 1995.

ASSOCIATION OF OPERATING ROOM NURSES. Recommended practices for selection and use of surgical gowns and drapes. AORN. J, v. 77, n. 1, p. 206-13, 2003.

ASSOCIAÇÃO PAULISTA DE ESTUDOS E CONTROLE DE INFECÇÃO HOSPITALAR (APECIH). Infecções hospitalares no Brasil. Jun. 2005. Disponível em: <http:// apecih.org.br / infecções - hospitalares.htm>. Acesso em 20 de out. de 2006.

ATALLAH, A.N. Medical controversies and systematic reviews: the heat and the light. São Paulo Med J , v. 115, n. 2, p. 1381, 1997.

ATALLAH, A.N.; CASTRO, A.A. Revisão sistemática da literatura e metanálise: a melhor forma de evidência para tomada de decisão em saúde e a maneira mais rápida de atualização terapêutica, 1998. Disponível em : <http: www. centrocochranedobrasil.org.br/ artigos/ rls.htm>. Acesso em mar. de 2006. 
BARATA, R.B. Medicina baseada em evidências: novo paradigma assistencial e pedagógico? Interface- Comunic Saúde, v. 6, n.11, p. 117-32, 2002

BECK, N.C.; COLLETTE, T.S. False faith in the surgeon's gown and surgical drape. Am. J. Surg, v. 523, n. 1, p.125-26, 1953.

BELKIN, N.L. A historial review of barrier materials. AORN. J , v. 6, n. 4, p. 64853, 2002.

BELKIN, N.L. Evaluating surgical gowing, draping fabrics. AORN. J, v. 34, n. 3, p. 499, 1981.

BELKIN, N.L. Evaluating the protective value of hospital gowns. Am. J. Infect. Control, v. 27, n. 2, p.178-79, 1999.

BELKIN, N.L. Testing surgical gowns for the antecipated level of exposure. J. Laparoend. Ad. Surg. Tech, v. 10, n. 2, p.119-22, 2000.

BURGATTI, J.C.; POSSARI, J.F.; MODERNO, A.M.B. Avaliação da barreira microbiana do campo cirúrgico simples de algodão. Rev. SOBECC, v. 9, n.1, p. 2432,2004

CASTIEL, L.D.; POVOA, E.C. Medicina baseada em evidências: novo paradigma assistencial e pedagógico? Interface- Comunic Saúde, v. 6, n. 11, p. 117-32, 2002

CASTRO, A.A; SACONATO, H.; GUIDUGLI, F.; CLARK, O.A.C. Curso de revisão sistemática e metanálise. São Paulo: LED-DIS/UNIFESP, 2002. Disponível em: < http:// www.virtual.epm.br/cursos/metanalise >. Acessível em 10 de marc. de 2006.

YALE UNIVERSITY SCHOOL OF MEDICINE. Cushing, H; Whitney, J.H Medical Library, 2005. Disponível em: <http:// www.ebm.pyramid.org/samples/complicated.htm>. Acessível em 25 de janeiro de 2007.

DUNN, D.L.; BEILMAN, G.J. Surgical Infections. In Schwartz's Principles of Surgery. Estados Unidos: The McGraw-Hill Companies, 2004, cap. 5. Disponível em: <http:// www.acessmedicine.com/resourceTOC.aspx?resourceID=50>.Acessível em 15 de abr. de 2006. 
EUROPEAN STANDARD EN 13795-1. Surgical drapes, gowns and clean air suits, used as medical devices for patients, clinical staff and equipment- Part1- general requirements for manufacturers, processors and products, June. 2002.

FERNANDES, A.T.; RIBEIRO FILHO, R.N.; BARROSO, E. Conceito, cadeia epidemiológica das infecções hospitalares e validação custo-benefício das medidas de controle. In: FERNANDES, A.T.; FERNANDES, M.O.; FILHO, N.R. Infecçãa hospitalar e suas interfaces na área da saúde. São Paulo: Atheneu, 2000. cap. 38, p.789-818. $1 \mathrm{v}$.

FLETCHER, R.H.; FLETCHER, S.W. Epidemiologia clínica elementos essenciais. 4. ed. São Paulo: Artmed, 2006. cap. 8, p.154-78.

GARCIA, P.G. Paramentação cirúrgica: aventais. In: LACERDA, R. Controle de Infecção em Centro Cirúrgico Fatos, Mitos e Controvérsias. São Paulo: Atheneu, 2003. cap. 5, p.69-84.

GARNER, J.S. Guideline for isolation precautions in hospital. Infect. Control. Hosp. Epidemiol, v.17, n. 1, p. 50-80, 1996.

GARNER, J.S.; JARVIS, W.R.; EMORI, T.G. et al. CDC definitions of nosocomial infections. Am. J. Infect. Control, v. 16, p. 128-40, 1988.

GOUVEIA, V.R. Embalagens para esterilização de tecidos e não-tecidos. Rev. SOBECC, v. 2, n. 4, p.10-2, 1997.

HAYNES, B.; HAINES, A. Barriers and bridges to evidence based clinical practice. BMJ, v. 317, p. 273-6, 1998.

HEISS, M.M.; MEMPEL, W.; JAUCH, K.W, et al. Beneficial effect of autologous blood transfusion on infectious complications after coloretal cancer surgery. Lancet, v. 342, p. 1328-33, 1993.

HORAN, T.C.; GAYNES, R.P.; MARTONE, W.J. et al. CDC definitions of nosocomial surgical site infections, a modification of CDC definitions of surgical wound infections. Infect. Control. Epidemiol, v. 13, p. 606, 1992.

JADAD, A.R.; MOORE, A.; CARROLL, D.; JENKINSON, C.; REYNOLDS, D.J.; GAVAGHAN, D.J.; MCQUAY, J. Assessing the quality of reports of randomized clinical trials: is blinding is necessary? Controlled Clinical trials, v. 17, p. 1-12, 1996. 
KLUYTMANS, J. Surgical infections including bums. In: WENZEL, R.P. Prevention and control of nosocomial infections. Baltimore: Willians \& Wilkins, 1997. p.841-65.

KOCH, F.; JAMES, E. Single use/ Multiple use gowns and drapes: criteria for decision making. Todays OR Nurse, v. 17, n. 2, p. 21-5, 1995.

LACERDA, R.A. Ambiente da sala de operação: fontes de contaminação e relação com infecção em centro cirúrgico. In: Controle de Infecção em Centro Cirúrgico: fatos, mitos e controvérsias. São Paulo: Atheneu, 2003. p. 325-60.

LACERDA, R.A. Exposição ocupacional ao sangue e a outras substâncias orgânicas de pacientes em unidades de centro cirúrgico de hospitais do Brasil. 2000. Tese (livre-docência). Escola de Enfermagem da USP, São Paulo, 2000.

LACERDA, R.A. Infecção do sítio cirúrgico. In: Controle de Infecção em Centro Cirúrgico fatos, mitos e controvérsias. São Paulo: Atheneu, 2003. p.69-84.

LACERDA, R.A. Paramentação cirúrgica: importância no controle da infecção em centro cirúrgico. In: Controle de Infecção em Centro Cirúrgico: fatos, mitos e controvérsias. São Paulo: Atheneu, 2003. p.261-75.

LANKESTER, B.J.A.; BARTLETT, G.E.; GARNETI, N.; BLOM, A.W.; BOWKER, K.E.; BANNISTER, G.C. Direct measurement of bacterial penetration through surgical gowns: anew method. J. Hosp. Infect, v. 50, p. 281-85, 2002

LAST, J.M. A dictionary of epidemiology. New York: Oxford University Press, 1988.

LAUFMAN, H. Surgical barrier materials: Product promotion vs. controlled evidence. Bull. Am. Coll. Surg, v. 67, n. 5, p.13-17, 1982.

LEONAS, K.K.; JINKINS, R.S. The relationship of selected fabric characteristics and the barrier effectiveness of surgical gown fabrics. Am. J. Infect. Control, v. 25, p.16-23, 1997.

LEONAS, K.K. Effect of laundering on the barrier properties of reusable surgical gowns fabrics. Am. J. Infect. Control, v. 26, n. 5, p. 495-501, 1998. 
MANGRAM, A.J.; HORAN, T.C.; PEARSON, M.L.; SILVER, L.C.; JARVIS, W.R. Guideline for prevention of surgical site infection. Infect. Control. Hosp. Epidemiol, v. 20, n. 4, Jan 1999. Disponível em: <http://www.cdc.gov>. Acesso em 02 de agosto de 2006 .

MCCULLOUGH, E.A. Methods for determining the barrier efficacy of surgical gowns. Am. J. Infect. Control , v. 21, n. 6, p. 368-73, 1993.

MINISTÉRIO DA SAÚDE (BR). Portaria n. 2616, de 12 de maio de 1998. Brasília (DF): Ministério da Saúde, 1998.

MONTEIRO, C.E.E.; LACERDA, R.A.; PAZ, M.S.O.; CONCEIÇÃO, V.P. Paramentação cirúrgica: avaliação de sua adequação para a prevenção de riscos biológicos em cirurgias - parte II: os componentes da paramentação. Rev. Esc. Enf. USP, v. 34, n. 2, p. 185-95, 2000.

MOORE, F.A.; MOORE, E.E.; JONES, T.N et al. TEM versus TPN following mayor abdominal trauma-reduced septic morbidity. J. Trauma, v. 29, p. 916, 1989.

MORYA, G.A. Avaliação da manutenção da esterilidade de materiais molhados/ úmidos após autoclavação e armazenamento. 2005. Dissertação (Mestrado em Enfermagem na Saúde do Adulto) - Escola de Enfermagem da USP, São Paulo, 2005 .

NOBRE, M.R.C.; BERNARDO, W.M.; JATENE, F.B. A prática clínica baseada em evidências: parte III - avaliação crítica das informações de pesquisas clínicas. Assoc. Méd. Bras, v. 50, n. 2, p. 221-28, 2004.

NOBRE, M.R.C.; BERNARDO, W.M. Busca de evidências em fontes de informação científica. In: Prática clínica baseada em evidências. São Paulo: Elsevier, 2006. p. 43-57.

OLSEN, O.; MIDDLETON, P.; EZZO, J.; GOTZSCHE, P.C et al. Quality of Cochrane reviews: assessment of sample from 1998. BMJ , v. 323, p. 829-32, 2001.

PAZ, M.S.O.; LACERDA, R.A.; MONTEIRO, C.E.C.; CONCEIÇÃO, V.P. Paramentação cirúrgica: avaliação de sua adequação para a prevenção de riscos biológicos em cirurgias. Rev. Esc. Enf. USP, v. 34, n.1, p.108-117, 2000. 
PISSIOTIS, C.A.; KOMBOROZOS, V.; PAPOUTSI, C; STREKAS, G. Factors that influence the effectiveness of surgical gowns in the operating theatre. Eur. J. Surg, v.163, p.597-604, 1997.

RABHAE, G.N.; RIBEIRO FILHO, N.; FERNANDES, A.T. Infecção do sítio cirúrgico. In: FERNANDES, A.T.; FERNANDES, M.O.; FILHO, N.R. Infecção hospitalar e suas interfaces na área da saúde. São Paulo: Atheneu, 2000. cap. 19, $1 \mathrm{v}$.

RODRIGUES, E. Reutilização de campos duplos de tecido de algodão padronizados pela ABNT para embalagens de artigos médico-hospitalares na esterilização por calor úmido. Tese. Escola de Enfermagem da USP, São Paulo, 2000 .

RUTALA, N.A.; WEBER, D.J. A review of single-use and reusable gowns and drapes in health care. Infect. Control. Hosp. Epidemiol, v. 22, n. 4, p. 248-57, 2001 .

SIQUEIRA, L.F.G. Síndrome do edifício doente, o meio ambiente e a infecção hospitalar. In: FERNANDES, A.T.; FERNANDES, M.O.; FILHO, N.R. Infecção hospitalar e suas interfaces na área da saúde. São Paulo: Atheneu, 2000. cap.72, 2 v.

STANEWICK, B.; KOGUT, N. Packaging: textiles. Maryland: Aspen, 1993. cap. 9, p.77-84.

TCHERVENKOS, J.I.; MEAKINS, J.L. Altered host defense mechanisms in septic patients. In: Fry DE ed. Surgical infections Boston: Littie Brown and Company, 1995.

TELFORD, G.L.; QUEBBEMAN, E.J. Assessing the risk of blood exposure in the operating room. Am. J. Infect. Control, v. 21, p. 351-56, 1993.

THE COCHRANE REVIEWERS `HANDBOOK GLOSSARY. Version 4.1.2. The Cochrane Collaboration, marc. 2001. Disponível em $:<\mathrm{http}: / /$ www.cochrane.dk/cochrane/handbook/handbook.htm $>$.Acesso em 02 de dezembro de 2006.

VAN DE MEER, J.W.M. Defects in host defense mechanisms. In: RUBIN, R.H, YOUNG, L.S ed. Clinical approach to infection in the compromised host. New York: Plenum Press, 1986. 
VERWAAL, V.J.; WOBBES, T.; KOOPMAN VAN GERMET, A.W. et al. Effect of operative blood transfusion and cell saver on the incidence of postoperative infection complications in patients with aneurysm of the abdominal aorta. Eur. J. Surg, v. 158, p. 477-80, 1992.

WHITTERMORE, R. Combining evidence in nursing research: methods and implications. Nurs. Res, v. 54, n. 1, p. 56-62, jan-feb 2005.

WONG, E.S. Surgical site infection. In: Mayhall CG (ed) Hospital Epidemiology and Infect Control. Philadelphia: Lippincott Willians Wilkins, 1999. 


\section{APÊNDICE 1}

Quadro I - Descritores indexados, classificados por intervenção, comparação e desfecho.

\begin{tabular}{|l|l|l|}
\hline I- INTERVENÇÃO & C- COMPARAÇÃO & O- DESFECHO \\
\hline Clothing & Disposable-equipment & Surgical wound infection \\
\hline Protective clothing & & Postoperative infection \\
\hline Operating room & & \\
\hline Bedding and linens & & \\
\hline Textiles & & \\
\hline Cotton & & \\
\hline
\end{tabular}

Quadro II - Descritores não indexados, classificados por intervenção, comparação e desfecho.

\begin{tabular}{|l|l|l|}
\hline I- INTERVENÇÃO & C- COMPARAÇÃO & O- DESFECHO \\
\hline Reusable clothing & Single-use clothing & $\begin{array}{l}\text { Surgical } \\
\text { contamination }\end{array}$ \\
\hline Woven & Non-woven & Surgical site infection \\
\hline Surgical gowns & & \\
\hline Operative gowns & & \\
\hline Disposable gowns & & \\
\hline Drapes & & \\
\hline Operating room personnel & & \\
\hline Garments & & \\
\hline Staff clothing & & \\
\hline
\end{tabular}


APÊNDICE 2

Instrumento de Coleta de Dados dos Estudos Identificados.

\begin{tabular}{|l|l|}
\hline Título & \\
\hline Primeiro Autor & \\
\hline Ano de Publicação & \\
\hline País de Publicação & \\
\hline Tipo de Estudo & Reutilizável: \\
\hline Participantes & \\
\hline Tipos de Aventais & Uso-único: \\
\hline Desfechos & Contaminação da Ferida Operatória: \\
\hline Incluir: & Infecção do Sítio Cirúrgico: \\
\hline Motivo da Exclusão & Excluir: \\
\hline
\end{tabular}




\section{APÊNDICE 3}

\section{Instrumento de Coleta de Dados dos Estudos Incluídos.}

\begin{tabular}{|c|c|}
\hline Número do Estudo & \\
\hline Título & \\
\hline Autores & \\
\hline Ano de Publicação & \\
\hline País de Publicação & \\
\hline Referências & \\
\hline Escopo & \\
\hline Ensaio clínico & ( ) $\operatorname{sim}$ ( ) não \\
\hline Randomização & ( ) $\operatorname{sim}$ ( ) não \\
\hline Controlado & ( ) $\operatorname{sim}$ ( ) não \\
\hline Cegamento & ( ) uni- cego ( ) duplo cego ( ) triplo cego ( ) aberto \\
\hline Outro tipo de investigação & Qual: \\
\hline $\begin{array}{l}\text { n grupo experimental } \\
\text { n grupo controle } \\
\text { n geral } \\
\text { Critérios de inclusão } \\
\text { Critérios de exclusão }\end{array}$ & \\
\hline $\begin{array}{ll}\text { Cálculo estatístico para } \\
\text { suficiência da amostra }\end{array}$ & ( ) sim ( ) não ( ) não informado \\
\hline Tempo de seguimento & \\
\hline $\begin{array}{l}\text { Perda de participantes da } \\
\text { amostra } \\
\text { Razões }\end{array}$ & ( ) $\operatorname{sim}$ ( ) não ( ) não informado \\
\hline Tipo de material & 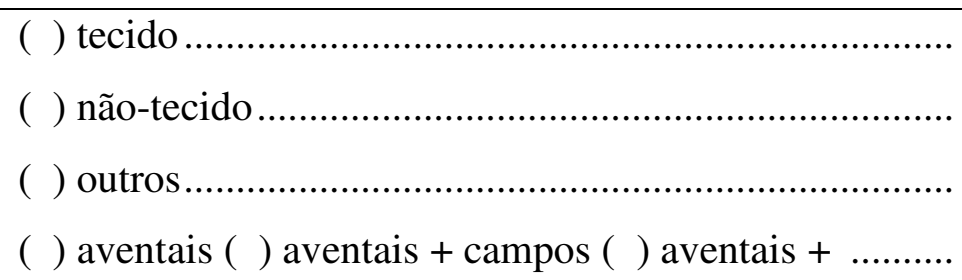 \\
\hline
\end{tabular}




\begin{tabular}{|c|c|}
\hline $\begin{array}{l}\text { Desfecho (contaminação ou } \\
\text { ISC } \\
\text { (critérios usados para } \\
\text { diagnosticar) }\end{array}$ & $\begin{array}{l}\text { ( ) infecção do sítio cirúrgico: } \\
\text { ( ) contaminação da ferida operatória: }\end{array}$ \\
\hline Cenário & $\begin{array}{l}\text { ( ) pesquisa de campo ( ) simulação ( ) laboratório } \\
\text { Método: }\end{array}$ \\
\hline Fomento/conflito interesse & \\
\hline $\begin{array}{l}\text { Controle de variáveis } \\
\text { independentes (VI) }\end{array}$ & ( ) \\
\hline Notas: & \\
\hline
\end{tabular}

\section{Revisor}




\section{APÊNDICE 4}

\section{Estudos excluídos e seus respectivos motivos}

\begin{tabular}{|c|c|}
\hline ESTUDO & MOTIVO DE EXCLUSÃO \\
\hline SCHEIBEL, 1991 & $\begin{array}{l}\text { Comparou o uso de uniforme privativo convencional pelo pessoal da sala } \\
\text { de operação com as coberturas de polipropileno, a fim de verificar redução } \\
\text { da contaminação bacteriana do ar e da ferida operatória. }\end{array}$ \\
\hline BLOMGREN, 1990 & $\begin{array}{l}\text { Estudou a contaminação do ar, do campo operatório e das feridas cirúrgicas } \\
\text { em artroplastia de quadril total, comparando o uso de uniforme privativo de } \\
\text { polipropileno pelo pessoal da sala de operação com roupas de algodão } \\
\text { convencional. }\end{array}$ \\
\hline TAMMELIN, 2000 & $\begin{array}{l}\text { Traçou a fonte e a rota de transmissão do Stapylococcus epidermidis } \\
\text { resistente a meticilina para a ferida cirúrgica durante cirurgia cardiotorácica } \\
\text { e avaliou a possibilidade de reduzir a contaminação da ferida operatória, } \\
\text { comparando o uso de uniforme privativo convencional com descartáveis, } \\
\text { porém toda equipe cirúrgica em ambos os grupos utilizou aventais } \\
\text { descartáveis. }\end{array}$ \\
\hline TAMMELIN, 2001 & $\begin{array}{l}\text { Traçou as rotas de transmissão e fontes do Stapylococcus aureus } \\
\text { encontrados em feridas cirúrgicas durante cirurgia cardiotorácica e } \\
\text { investigou a possibilidade de reduzir a contaminação da ferida, } \\
\text { considerando a contagem total de Stapylococcus aureus pelo uso de } \\
\text { uniforme privativo convencional versus descartável, porém a equipe } \\
\text { cirúrgica uso avental descartável. }\end{array}$ \\
\hline MOYLAN, 1975 & $\begin{array}{l}\text { Comparou o grau de penetração de microrganismos em aventais de tecidos } \\
\text { e descartáveis. Culturas foram obtidas antes e após as cirurgias no pré- } \\
\text { operatório (pele dos antebraços e abdome) e pós-operatório (pele e avental). }\end{array}$ \\
\hline MOYLAN, 1981 & $\begin{array}{l}\text { Duplicata, o mesmo artigo foi publicado em } 1980 \text { na Revista Surgery } \\
\text { Gynecology \& Obstetrics. }\end{array}$ \\
\hline TSUJÜ, 1981 & $\begin{array}{l}\text { Avaliou campos cirúrgicos na prevenção de infecção de sítio cirúrgico em } \\
\text { cirurgias de artroplastias. }\end{array}$ \\
\hline FRANCO, 1976 & $\begin{array}{l}\text { Verificou a contaminação da FO e ISC conforme o uso ou não de } \\
\text { paramentação de ar limpo em combinação ou não com fluxo laminar. }\end{array}$ \\
\hline
\end{tabular}

